US Army Corps of Engineers ${ }_{\circledast}$

Engineer Research and

Development Center

\title{
Physical Model Analysis of the Foster Joseph Sayers Dam
}

Ben Burnham, Marshall Thomas, and Jane Vaughan

December 2018

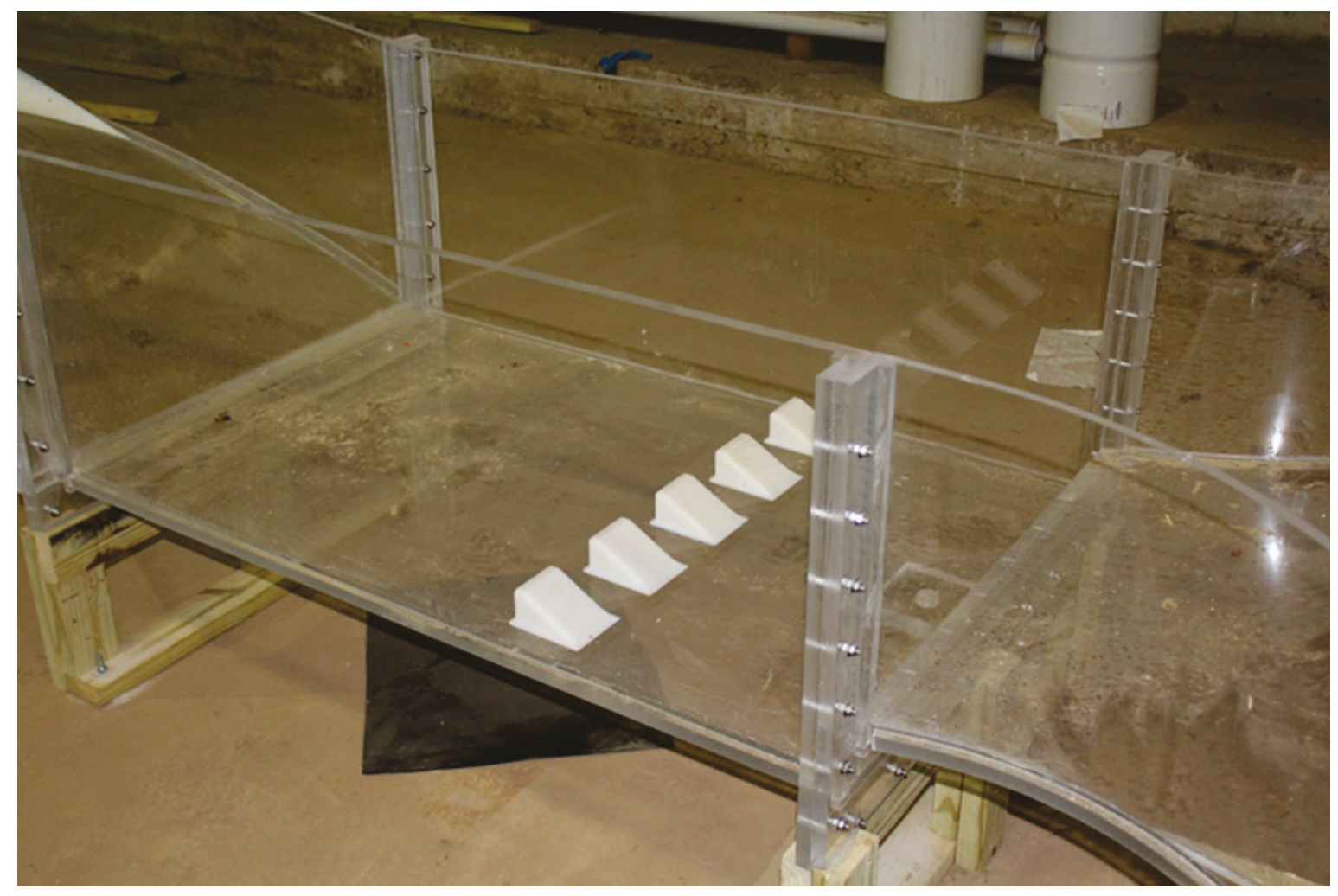


The U.S. Army Engineer Research and Development Center (ERDC) solves the nation's toughest engineering and environmental challenges. ERDC develops innovative solutions in civil and military engineering, geospatial sciences, water resources, and environmental sciences for the Army, the Department of Defense, civilian agencies, and our nation's public good. Find out more at www.erdc.usace.army.mil.

To search for other technical reports published by ERDC, visit the ERDC online library at http://acwc.sdp.sirsi.net/client/default. 


\section{Physical Model Analysis of the Foster Joseph Sayers Dam}

Ben Burnham, Marshall Thomas, and Jane Vaughan

Coastal and Hydraulics Laboratory

U.S. Army Engineer Research and Development Center

3909 Halls Ferry Road

Vicksburg, MS 39180-6199

Final report

Approved for public release; distribution is unlimited.

Prepared for U.S. Army Corps of Engineers, Baltimore District 2 Hopkins Plaza

Baltimore, MD 21201

Under Project no. 122098, "Stilling Basin-Stilling Basin Study/Repair" 


\section{Abstract}

Concrete degradation issues due to riprap entrainment have been observed in the stilling basin at Foster Joseph Sayers Dam. This entrapment occurs during normal flows. The original stilling basin has experienced excessive degradation, and repairs to restore it to original specifications are needed. A physical model study has been performed to determine the flow characteristics of the stilling basin and to develop a design modification to minimize riprap entrapment. The riprap originates in an area that could be replaced with a concrete pad to prevent further riprap entrainment in the stilling basin. A final stilling basin design modification recommendation is provided.

DISCLAIMER: The contents of this report are not to be used for advertising, publication, or promotional purposes. Citation of trade names does not constitute an official endorsement or approval of the use of such commercial products. All product names and trademarks cited are the property of their respective owners. The findings of this report are not to be construed as an official Department of the Army position unless so designated by other authorized documents. 


\section{Contents}

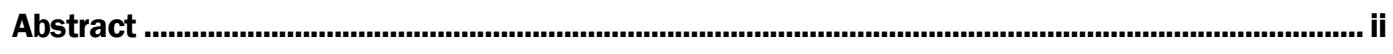

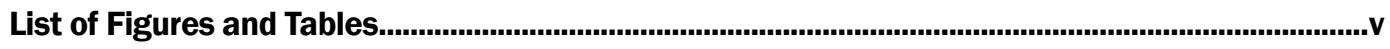

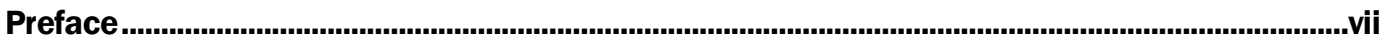

Unit Conversion Factors ................................................................................................................... vili

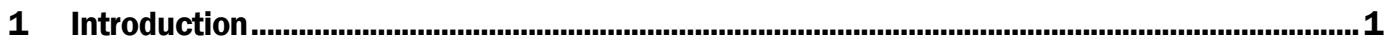

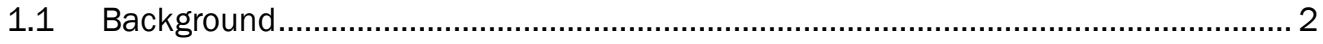

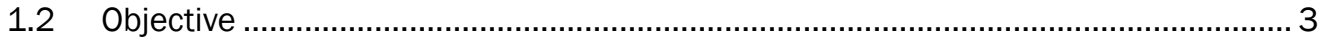

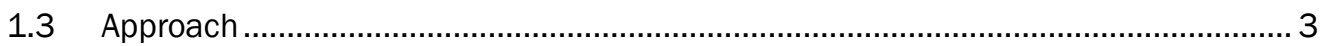

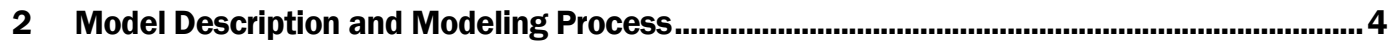

2.1 Foster Joseph Sayers Dam model scale relations ................................................. 8

2.2 Model description ....................................................................................... 8

2.2.1 Model description and construction .................................................................... 8

2.2.2 Elevation markers, point gages, and instrumentation......................................... 9

3 Model Results .........................................................................................................................13

3.1 Tests with a fixed bed exit channel................................................................ 13

3.1.1 Field discharge tests...................................................................................... 13

3.1.2 Physical model field discharge test observations .................................................. 15

3.1.3 Summer and winter pool elevation tests observations........................................... 16

3.1.4 Upper approach channel riprap observations.................................................... 17

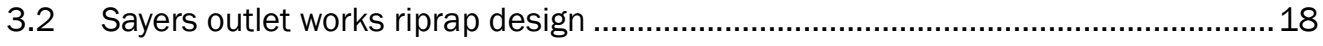

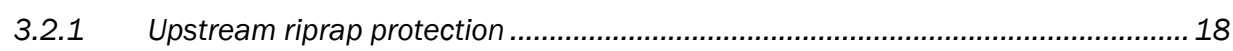

3.2.2 Downstream riprap protection .......................................................................... 19

3.2.3 Riprap for 18 in. thickness .......................................................................... 19

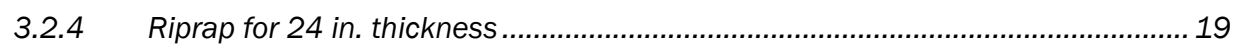

3.2.5 Riprap for 36 in. blanket thickness................................................................. 19

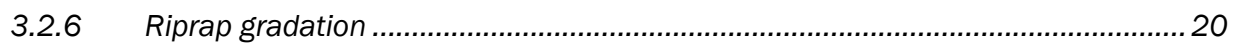

3.3 Tests with a movable bed exit channel .............................................................. 22

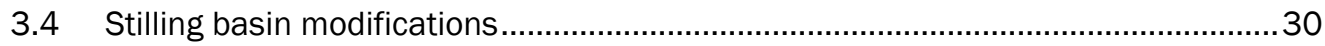

3.4.1 High-sloping fillet added to basin........................................................................ 30

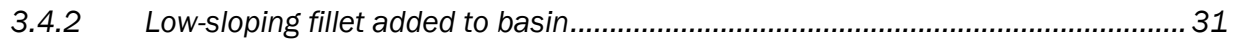

3.4.3 Inverted $V$ added to parabolic drop.................................................................... 35

3.4.4 Baffle blocks removed in stilling basin .............................................................. 41

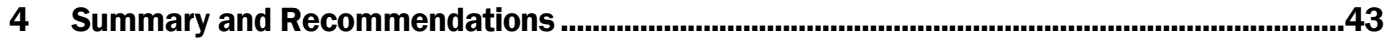

4.1 Summary of physical model study................................................................. 43

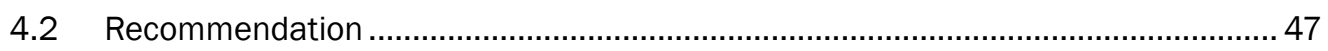

References .......................................................................................................................................49 


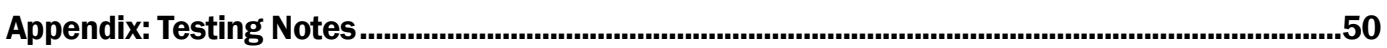

Report Documentation Page 


\section{List of Figures and Tables}

\section{Figures}

Figure 1. Photograph of Foster Joseph Sayers Dam and Outlet Works (Google Earth)........................ 1

Figure 2. Foster Joseph Sayers Dam location. ................................................................................... 2

Figure 3. Schematic of model outlet works. .................................................................................. 4

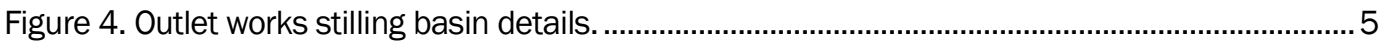

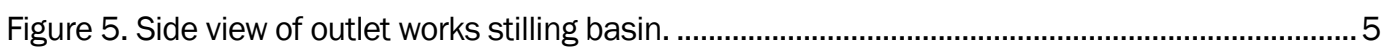

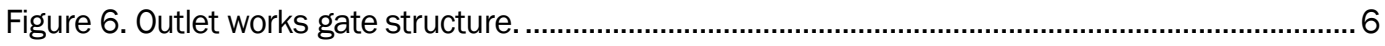

Figure 7. View looking downstream of trash rack and approach channel. ........................................... 6

Figure 8. View looking upstream of exit of culvert and trajectory fillets. ............................................. 7

Figure 9. Exit channel with tailgate looking upstream. …………………………………………......

Figure 10. Elevation marker - head bay. ....................................................................................

Figure 11. Elevation marker - exit channel...................................................................................10

Figure 12. Point gage - exit channel. ..........................................................................................10

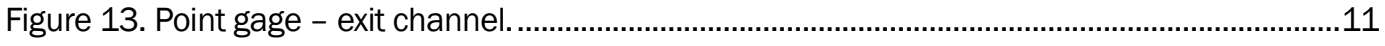

Figure 14. Ultrasonic flowmeter. ............................................................................................12

Figure 15. Ultrasonic flowmeter sensors location. ....................................................................12

Figure 16. View looking downstream of exit channel constructed of marine grade plywood............13

Figure 17. 18 in. blanket thickness gradation. ..............................................................................21

Figure 18. 24 in. blanket thickness gradation. ……………..........................................................2

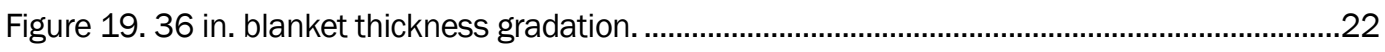

Figure 20. Movable bed exit channel with a discharge of 2,000 cfs............................................23

Figure 21. Dry bed view looking upstream of movable bed exit channel............................................24

Figure 22. 36 in. blanket thickness replaced with 18 in. blanket thickness looking

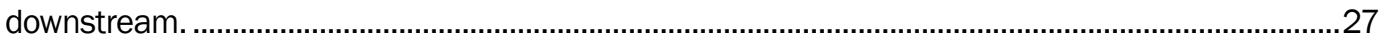

Figure 23. Cross view of $36 \mathrm{in}$. blanket thickness replaced with 18 in. blanket thickness...............27

Figure 24. High-slope 45-degree fillet added at the end sill in the stilling basin. ..............................31

Figure 25. 3D CAD drawing of fillet added in stilling basin. ..............................................................31

Figure 26. Fillet added in stilling basin; dimensions are in model inches. ........................................32

Figure 27. Fillet added in stilling basin, wet......................................................................................32

Figure 28. Fillet added in stilling basin, dry. .................................................................................3

Figure 29. CAD drawings of the inverted $V$ added to the parabolic trajectory..................................36

Figure 30. View of inverted $V$ added to parabolic trajectory..............................................................37

Figure 31. View looking upstream of inverted $V$ added to parabolic trajectory. ................................37

Figure 32. Side view of inverted $V$ added to parabolic trajectory. ......................................................38

Figure 33. View looking upstream with a discharge of $1,000 \mathrm{cfs}$ and the inverted $\mathrm{V}$ installed.

Figure 34. View looking downstream with a discharge of 1,000 cfs and the inverted V installed. 
Figure 35. Flow conditions in the stilling basin with a discharge of 5,000 cfs and the baffle blocks removed.

\section{Tables}

Table 1. Scale relations for the Foster Joseph Sayers Dam Physical Model ........................................

Table 2. Model field discharge testing............................................................................................14

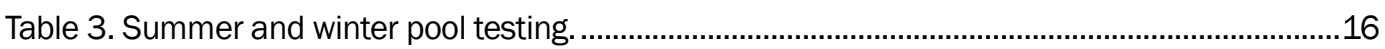

Table 4. Upstream rock movement testing ……………...............................................................

Table 5. Removable bed tests with 36 in. riprap blanket thickness. ..................................................25

Table 6. Movable bed tests with 18 in. blanket thickness in 36 in. zone...........................................28

Table 7. Movable bed tests with low-slope fillet piece.........................................................................34

Table 8. Movable bed tests with inverted V insert. ………….........................................................35

Table 9. Movable bed tests with no baffle blocks..............................................................................42 


\section{Preface}

The model investigation reported herein was sponsored by the U.S. Army Corps of Engineers (USACE), Baltimore District (NAB), under Project Number 122098, "Stilling Basin-Stilling Basin Study/Repair." This work was conducted in the Coastal and Hydraulics Laboratory (CHL) of the U.S. Army Engineer Research and Development Center (ERDC). Design and construction of the model and model experiments were conducted during the period of February 2016 to April 2018.

This research was conducted under the general direction of Mr. José E. Sánchez, Director of the CHL; Mr. Jeffrey Eckstein, Deputy Director, CHL; Dr. Jackie S. Pettway, Chief of the Navigation Division (CEERD-HNN), CHL; and Mr. Tim Shelton, Chief of the Navigation Branch (CEERDHNN-L), CHL. Brian Glock served as the technical point of contact in $\mathrm{NAB}$. Members of NAB visited CHL to observe model operation, discuss test results, and determine the need for modifications in design to improve the stilling basin performance. Members of NAB included Mr. Brian Glock, Ms. Julie Fritz, Ms. Lori Bank, Ms. Nicole Kennedy, Mr. Greg Crizer, and Mr. Kirk Wirth.

The model components were constructed and assembled by Mr. Hugh F. Acuff III and Mr. Zachary S. Smith, Directorate of Public Works (DPW), ERDC, under the supervision of Mr. Smith, Chief of Model Shop, DPW. Machine work was provided by Mr. Christopher M. Ables under the supervision of Mr. Mickey D. Blackmon, Chief of the Machine Shop, DPW.

This report was peer reviewed by Mr. John Hite of the ERDC and Mr. Brian Glock and Ms. Julie Fritz of the USACE NAB.

At the time of publication of this report, COL Ivan P. Beckman was Commander of ERDC, and Dr. David W. Pittman was Director. 


\section{Unit Conversion Factors}

\begin{tabular}{|l|l|l|}
\hline Multiply & By & To Obtain \\
\hline acres & 4046.856 & square meters \\
\hline acre-feet & 1233.489 & cubic meters \\
\hline cubic feet & 0.02831685 & cubic meters \\
\hline feet & 0.3048 & meters \\
\hline feet of water & 2988.98 & pascals \\
\hline miles (U.S. statute) & 1.609344 & kilometers \\
\hline
\end{tabular}




\section{Introduction}

Foster Joseph Sayers Dam (Figure 1) is located on Bald Eagle Creek approximately 1 mile downstream of Blanchard, PA, and 3.5 miles upstream of Howard, PA, as can be viewed in Figure 2. Forming Foster Joseph Sayers Reservoir, the dam has a storage capacity of 99,000 acrefeet at spillway crest, a reservoir surface area of 1,730 acres at summer conservation pool elevation, a length of approximately 6,835 feet (ft), a height of approximately $93 \mathrm{ft}$, and a normal summer and winter pool elevation of $630 \mathrm{ft}$ and $610 \mathrm{ft}$, respectively. The dam has a crest elevation of $683.0 \mathrm{ft}$ and a maximum pool elevation at design surcharge of $677.8 \mathrm{ft}^{1}$. Sayers Dam is owned and operated by the U.S. Army Corps of Engineers (USACE), Baltimore District (NAB).

Figure 1. Photograph of Foster Joseph Sayers Dam and Outlet Works (Google Earth).

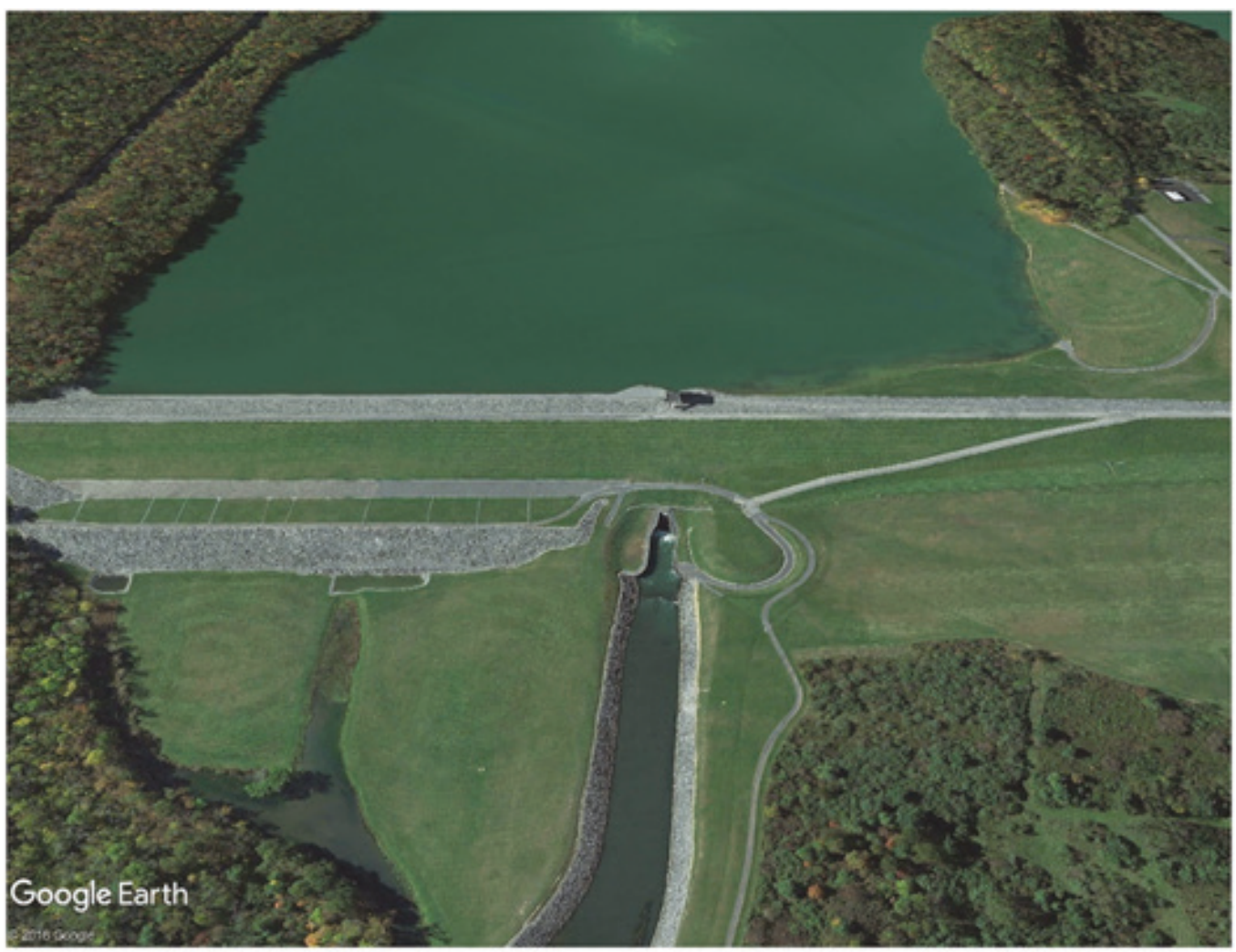

${ }^{1}$ All elevations cited herein are in feet referred to the National Geodetic Vertical Datum. 
Figure 2. Foster Joseph Sayers Dam location.

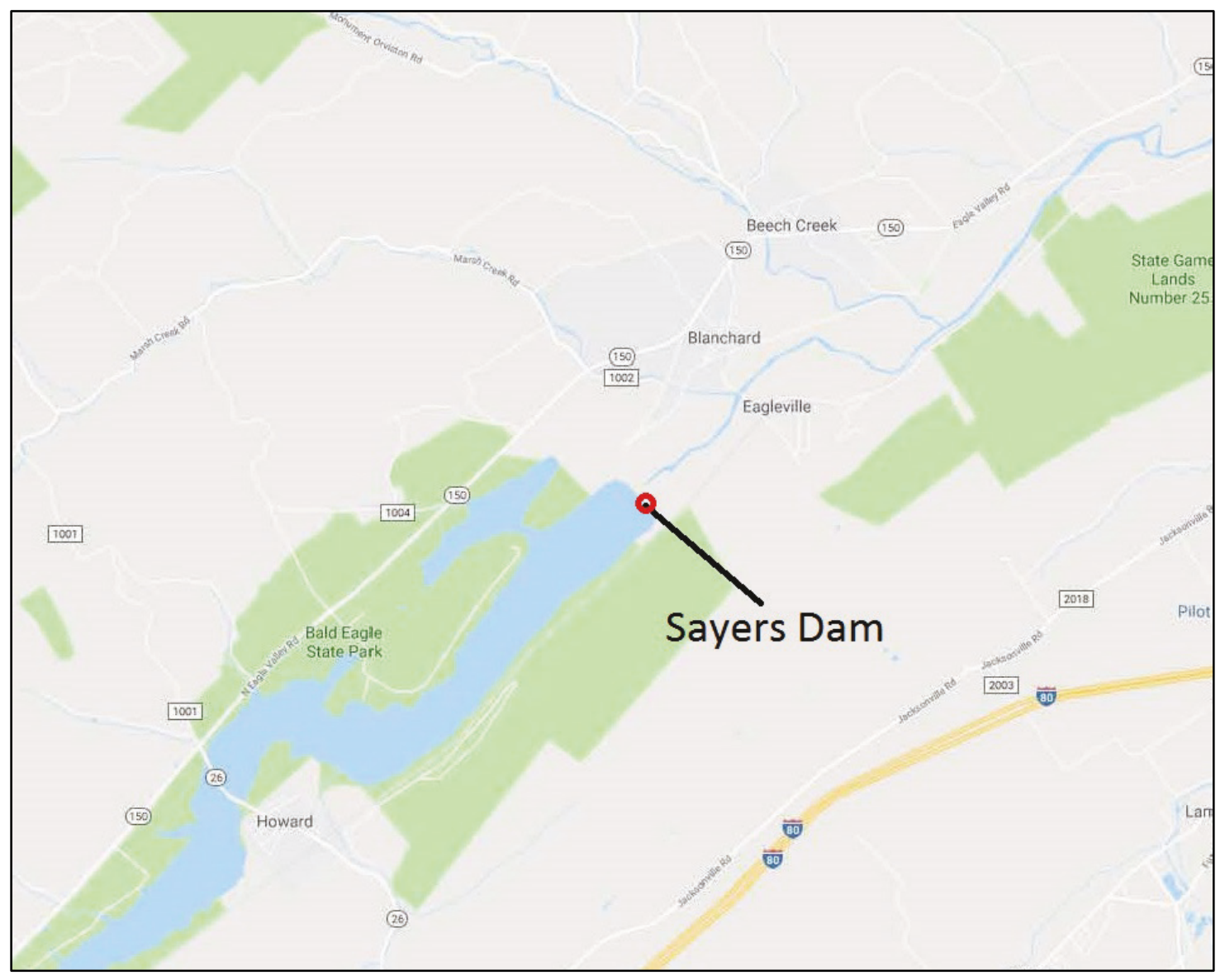

\subsection{Background}

Foster Joseph Sayers Dam has been in service since 1969. The primary functions of Foster Joseph Sayers Dam are to provide flood control protection of communities in the West Branch Susquehanna River basin, protect habitat and water quality, and increase public access within the Chesapeake Bay watershed. The dam consists of an earthen embankment, an uncontrolled emergency spillway, and an outlet works including an approach channel, intake structure, control tower, conduit transition, conduit, stilling basin, and exit channel. The single $15 \mathrm{ft}$ diameter conduit, $342.5 \mathrm{ft}$ long, is constructed of cut-and-cover concrete. Two $7 \times 15 \mathrm{ft}$ floodcontrolled passages operated by hydraulic slide gates provide operational regulation. Energy dissipation of the conduit discharge is achieved in a conventional hydraulic jump-type stilling basin, and outflow is returned to Bald Eagle Creek through a riprap-lined exit channel. Details of the outlet works stilling basin are shown in Figure 4. 
A diving inspection in 2006 alerted NAB that damage to the stilling basin had occurred and the cause was likely due to riprap entrapment. It is unclear when the damage to the stilling basin started to occur prior to the 2006 report, and there are no prior diving inspection reports available. The damage to the concrete in the stilling basin is caused by continued impact from riprap, believed to be coming from downstream of the stilling basin.

\subsection{Objective}

A physical model study was considered to evaluate the hydraulic performance of the stilling basin and exit channel and to develop proposed modifications to the stilling basin and exit channel to provide satisfactory performance. Specifically, the objective of the physical model study was to determine the following:

- existing flow conditions of the stilling basin

- potential modifications to the stilling basin to provide better flow characteristics within the stilling basin as well as flush riprap that may become trapped within the stilling basin walls

- investigate, design, and determine the location of a riprap protection blanket (concrete pad) downstream of the stilling basin to ensure riprap is not being pulled back into the stilling basin.

\subsection{Approach}

The approach used in this study was to analyze hydraulic characteristics of the stilling basin of Foster Joseph Sayers Dam physical model, plus compare ERDC physical model test results to field test results performed by $\mathrm{NAB}$, along with better understanding of riprap movement within the stilling basin and flushing out characteristics. Design alternatives and a recommendation would be provided to $\mathrm{NAB}$ that have the potential to reduce turbulent hydraulic characteristics of the stilling basin as well as reduced costs associated with the design and installation of a modification to reduce the amount of riprap entrapped within the basin.

As discussed in Chapter 3, a series of tests were performed to evaluate the existing hydraulic conditions of the stilling basin, as well as testing of several design modifications within the stilling basin to improve hydraulic performance and ensure riprap was being flushed out quickly. Results and recommendations were presented in Chapter 4. 


\section{Model Description and Modeling Process}

The physical model contains all the projects' hydraulic features affecting flow in the stilling basin. This consists of the upper reservoir with the upper approach channel, the gate structure with two independently operated lift gates, $15 \mathrm{ft}$ diameter culvert, the stilling basin, and an exit channel. Upstream of the upper reservoir, the model connects to existing pipe, which supplies water to the model. Downstream of the exit channel, the model connects to a flume that directs the flow to a drain. Schematics of the physical model are shown in Figure 3 and Figure 4. Photographs of the physical model are shown in Figure 5 to Figure 9.

Figure 3. Schematic of model outlet works.

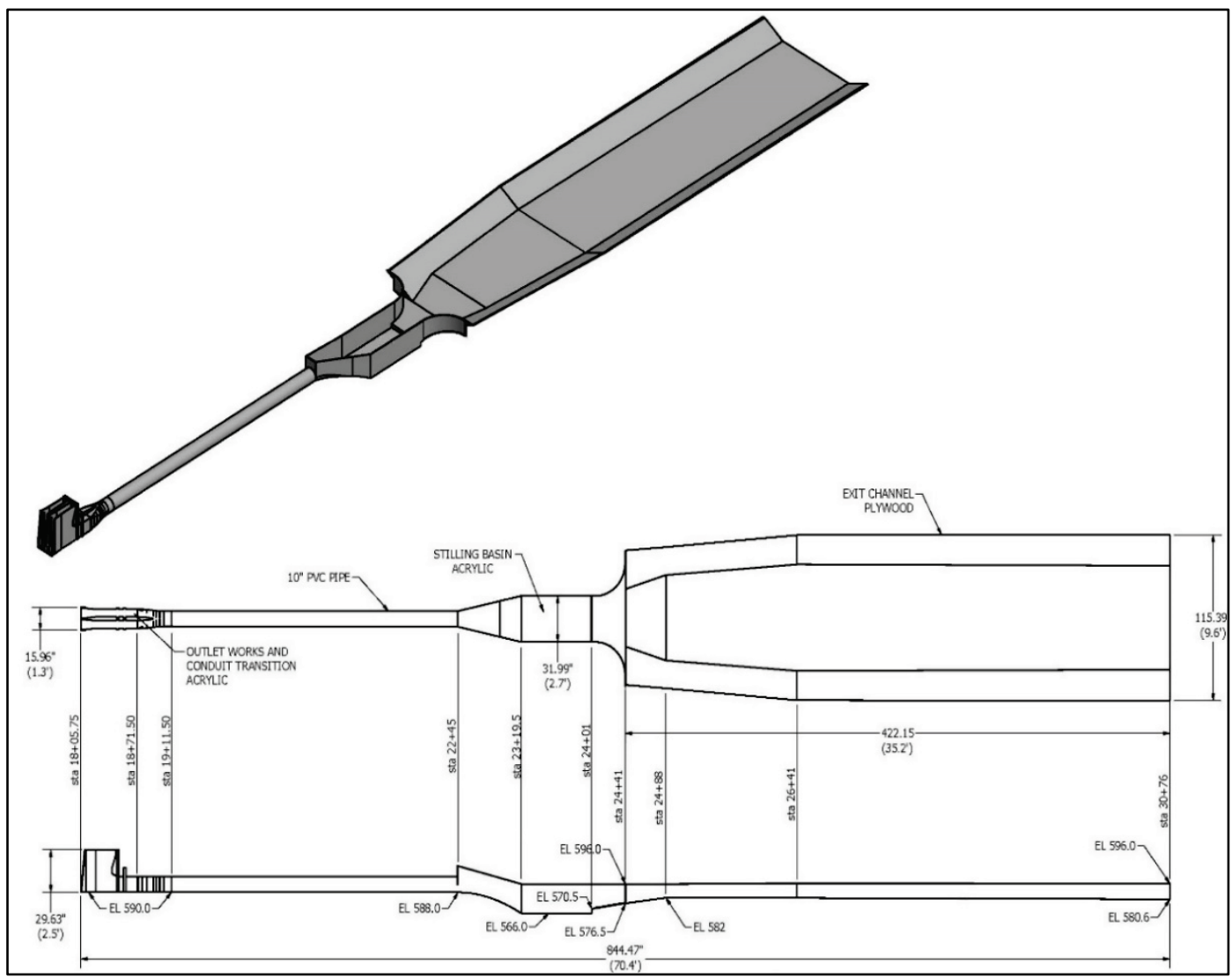


Figure 4. Outlet works stilling basin details.

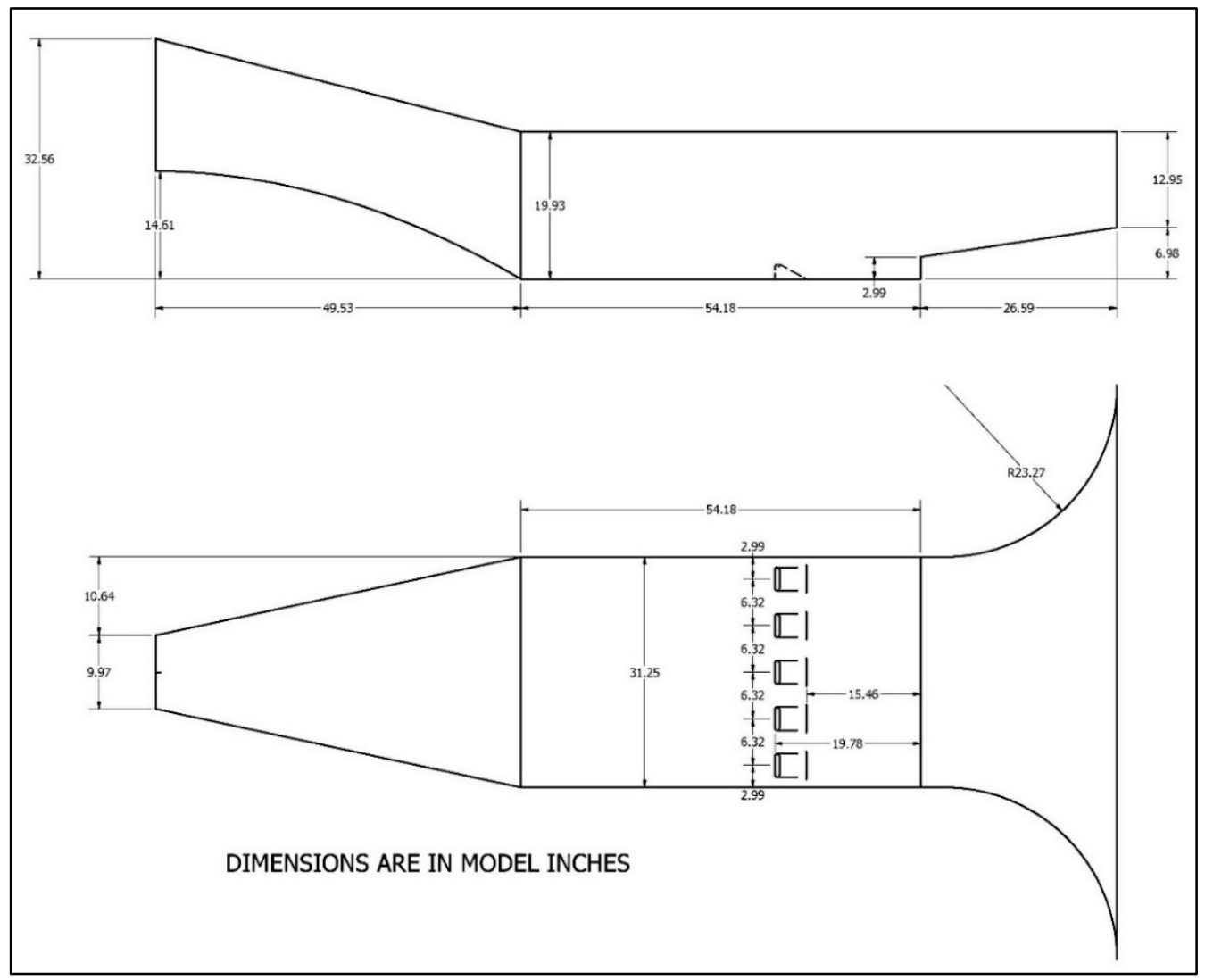

Figure 5. Side view of outlet works stilling basin.

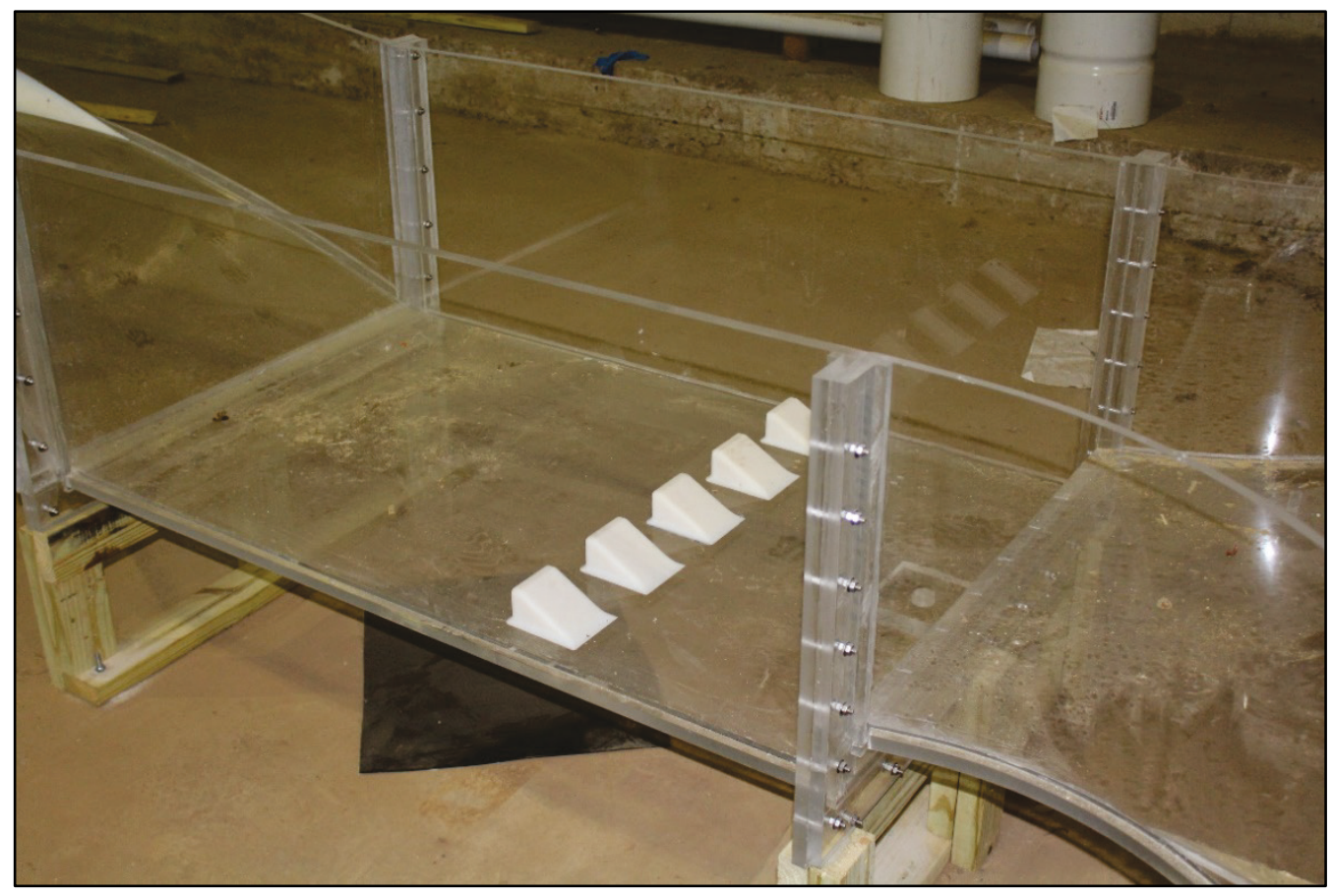


Figure 6. Outlet works gate structure.

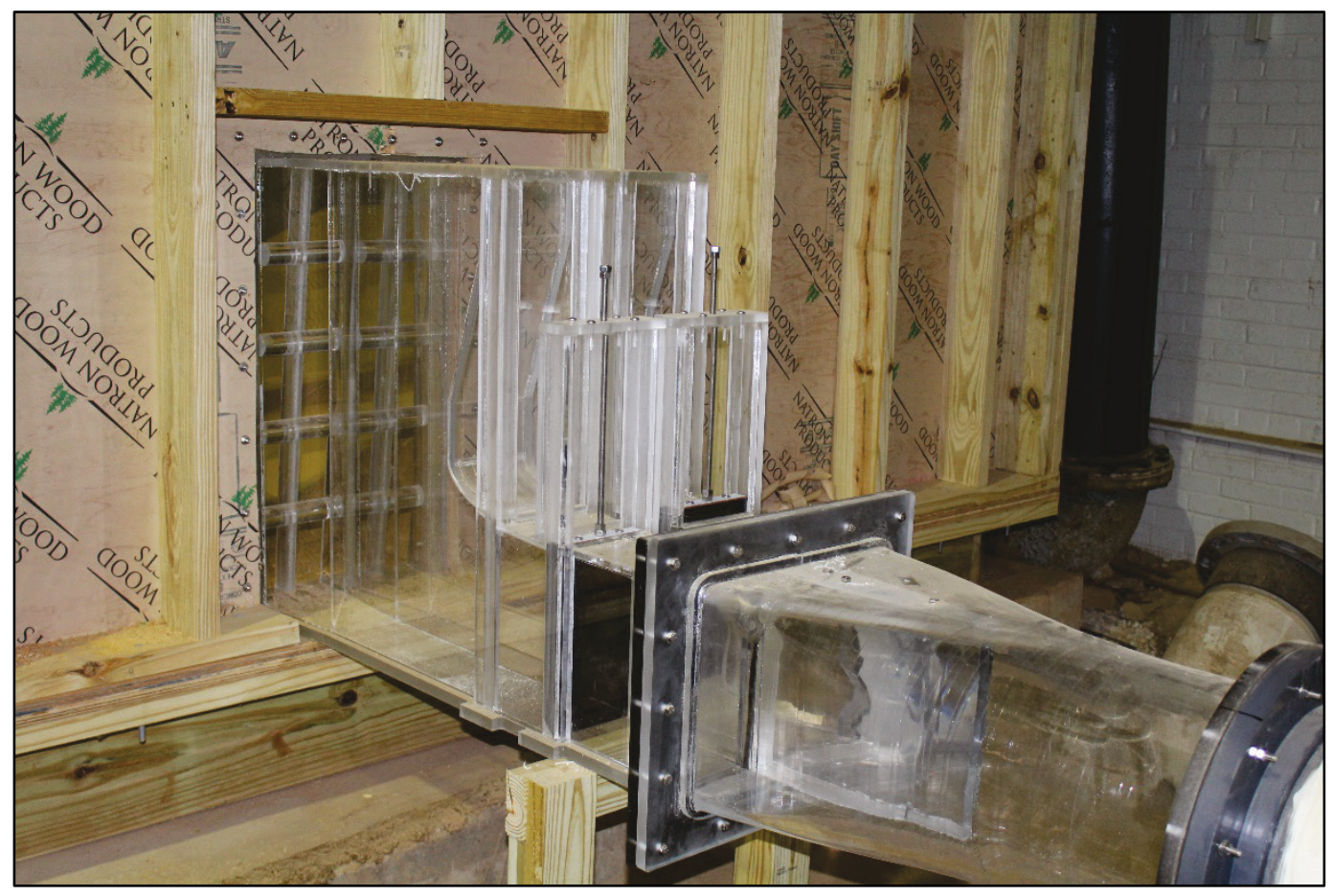

Figure 7. View looking downstream of trash rack and approach channel.

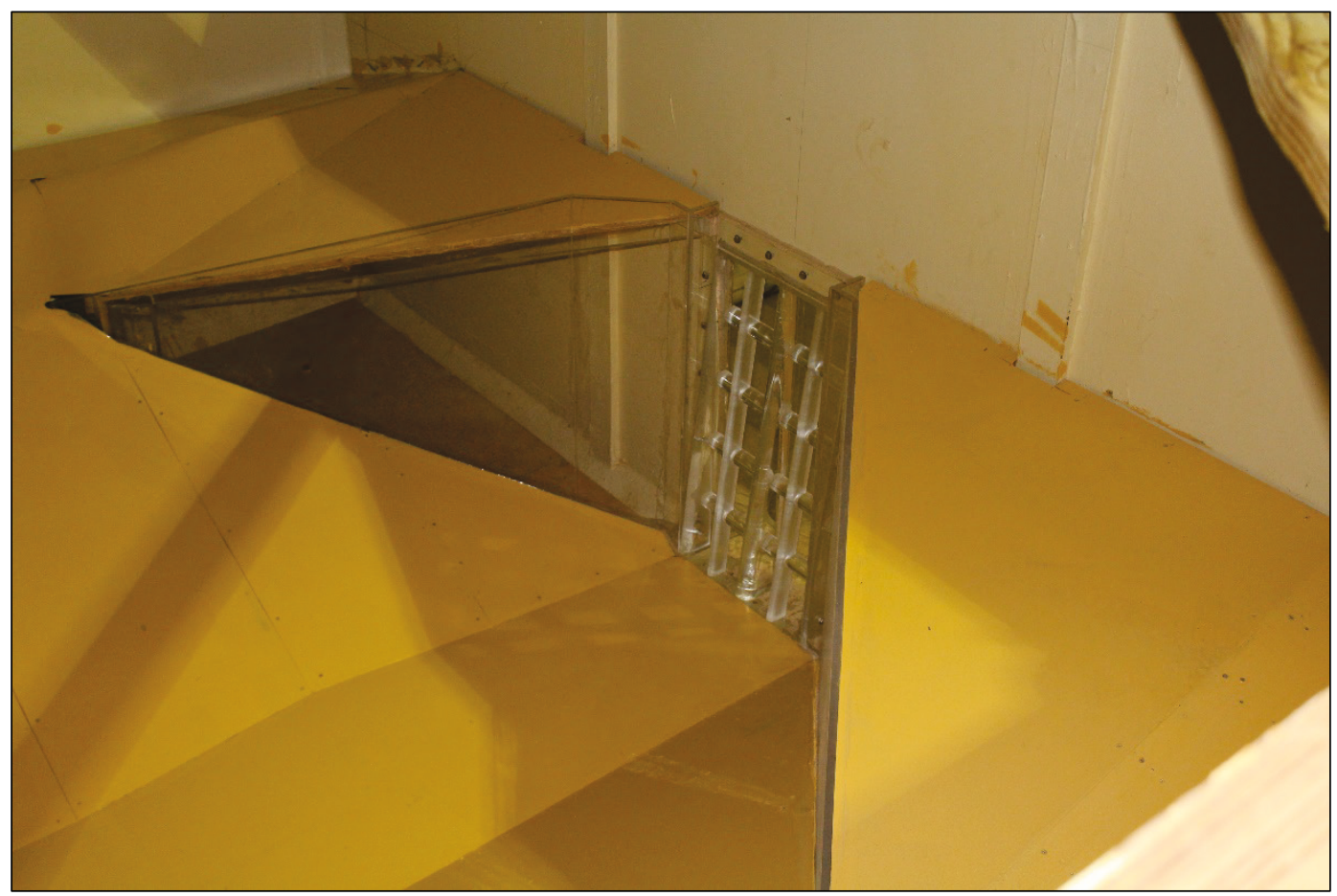


Figure 8. View looking upstream of exit of culvert and trajectory fillets.

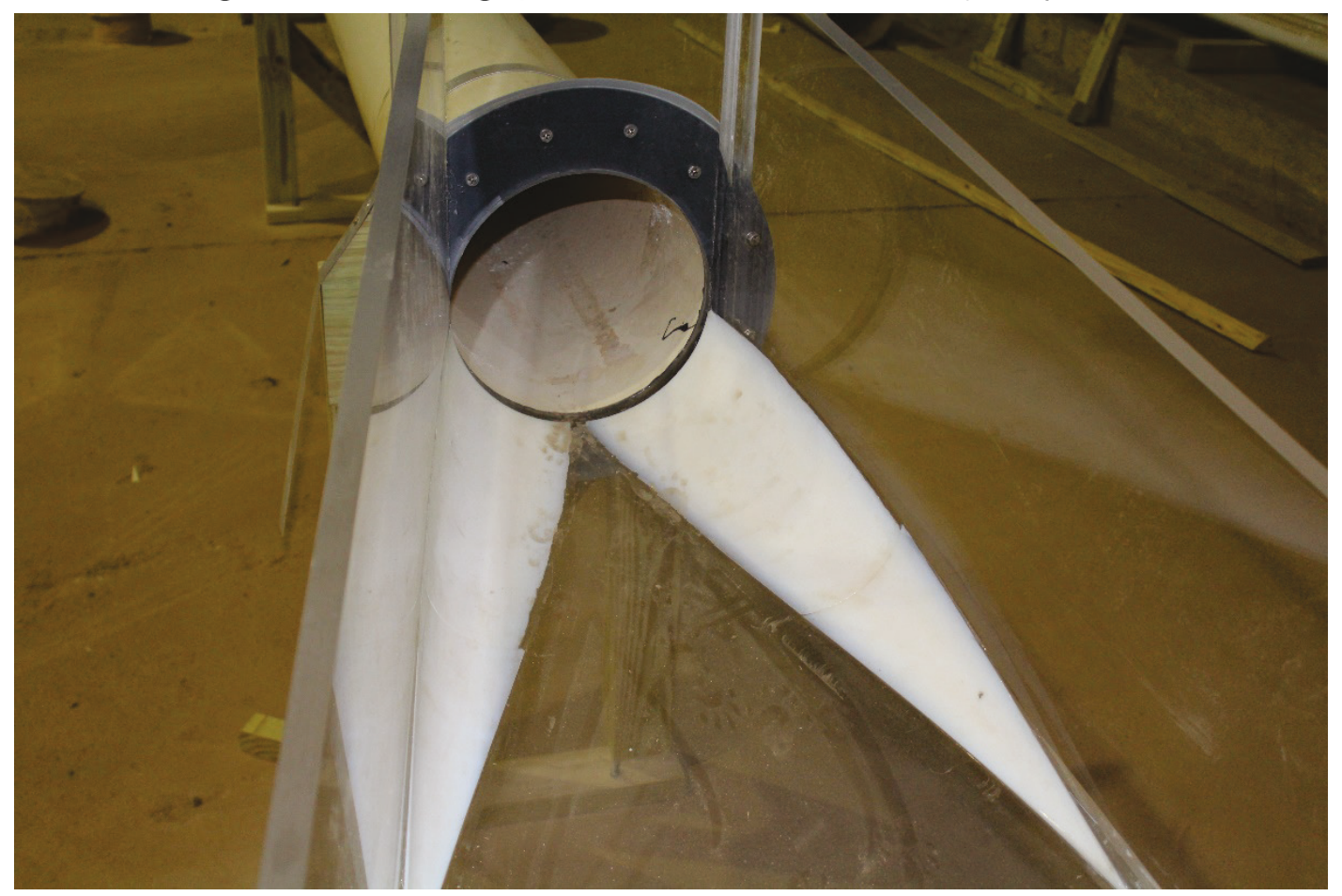

Figure 9. Exit channel with tailgate looking upstream.

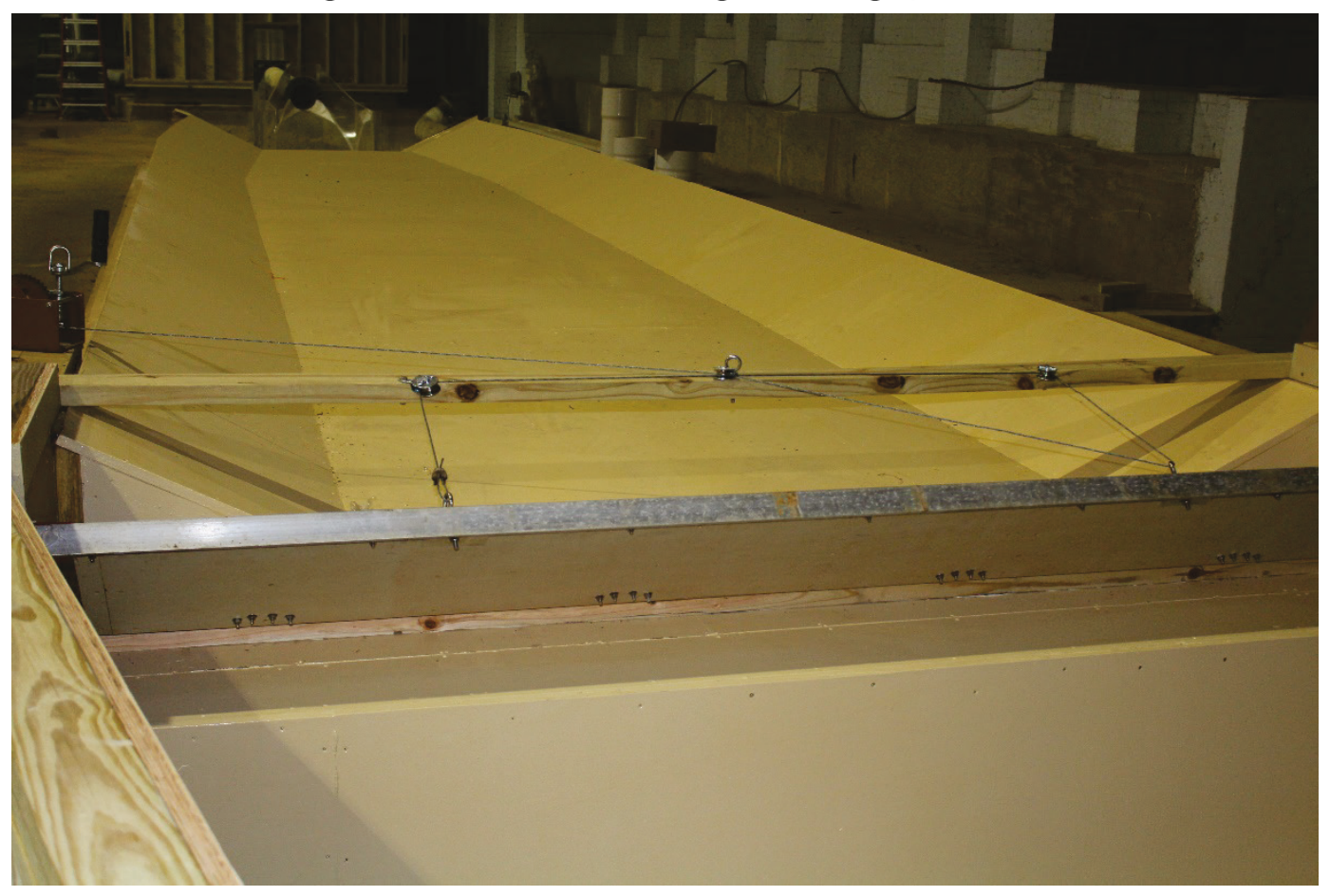




\subsection{Foster Joseph Sayers Dam model scale relations}

The facilities available at the U.S. Army Engineer Research and Development Center (ERDC), Coastal and Hydraulics Laboratory (CHL), and the scaling considerations led to the choice of a 1:18 scale model for the study. The scale relations and the ensuing scaling factors used for all quantities in this study are shown in Table 1.

Table 1. Scale relations for the Foster Joseph Sayers Dam physical model.

\begin{tabular}{|l|l|l|}
\hline Characteristic & Dimension & $\begin{array}{l}\text { Scale Relation } \\
\text { Model: Project }\end{array}$ \\
\hline Length & $\mathrm{L}_{r}=\mathrm{L}$ & $1: 18$ \\
\hline Area & $\mathrm{Ar}_{r}=\mathrm{Lr}^{2}$ & $1: 324$ \\
\hline Time & $\mathrm{T}_{r}=\mathrm{Lr}^{1 / 2}$ & $1: 4.243$ \\
\hline Velocity & $\mathrm{V}_{r}=\mathrm{Lr}_{r}^{1 / 2}$ & $1: 4.243$ \\
\hline Discharge & $\mathrm{Q}_{r}=\mathrm{L}_{r}^{5 / 2}$ & $1: 1374.616$ \\
\hline
\end{tabular}

${ }^{1}$ Dimensions are in terms of length.

\subsection{Model description}

\subsubsection{Model description and construction}

Three-dimensional (3D) computer-aided design (CAD) models of the approach channel, gate structure, stilling basin, and exit channel were constructed from as-built drawings provided by NAB. The CAD models were scaled to model dimensions and used to create shop drawings. The two lift gates were included in the model to control the amount of flow through the basin.

The 1:18-scale model reproduced a $216 \mathrm{ft} \times 216 \mathrm{ft}$ area of the reservoir, the gate structure, the entire length of conduit, the stilling basin, and $635 \mathrm{ft}$ of the exit channel. The gate structure and stilling basin walls were constructed of three-fourth-inch (in.) acrylic to allow direct observation of the flow through the gate structure and in the stilling basin. The approach channel was constructed of three-fourth in. marine grade plywood painted with a waterproof coating. For initial testing, the exit channel was constructed with the same marine grade plywood with waterproof coating.

For the second phase of testing, $198 \mathrm{ft}$ (prototype) of movable bed (riprap) was installed immediately downstream of the stilling basin. Details of the 
gradation of the riprap used in the exit channel are included in Section 3.2. The culvert was made of schedule 40 polyvinyl chloride. The lift gates in the gate structure were machined from a sheet of high-density polyethylene. Water was supplied to the model using a circulating system consisting of a large head tank, pumps, and a holding sump. Water was baffled inside the head bay to ensure an evenly distributed flow was introduced to the gate structure.

\subsubsection{Elevation markers, point gages, and instrumentation}

Elevation markers on the head bay and exit channel of the model were used to identify water-surface elevations. The elevation markers used can be seen in Figure 10 and Figure 11. A point gage was also used on the exit channel and can be seen in Figure 12 and Figure 13.

Figure 10. Elevation marker - head bay.

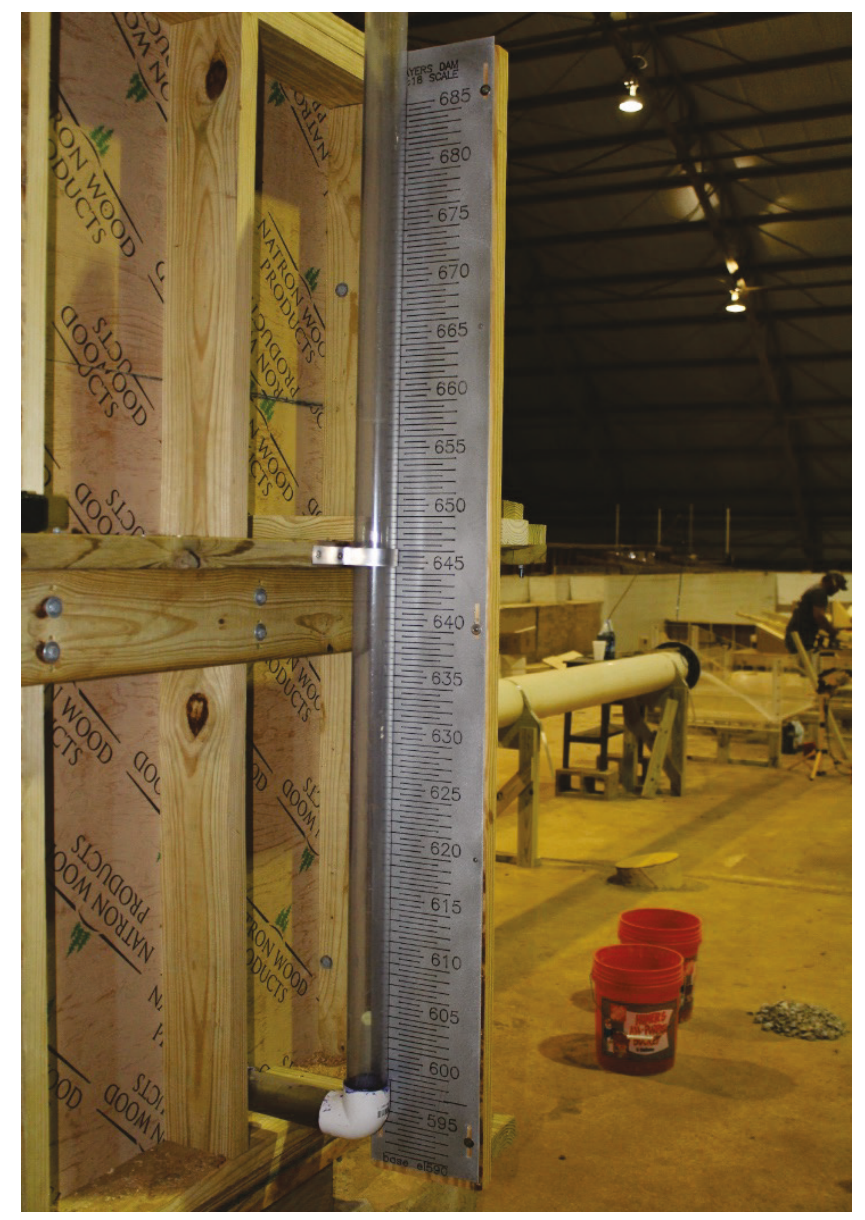


Figure 11. Elevation marker - exit channel.

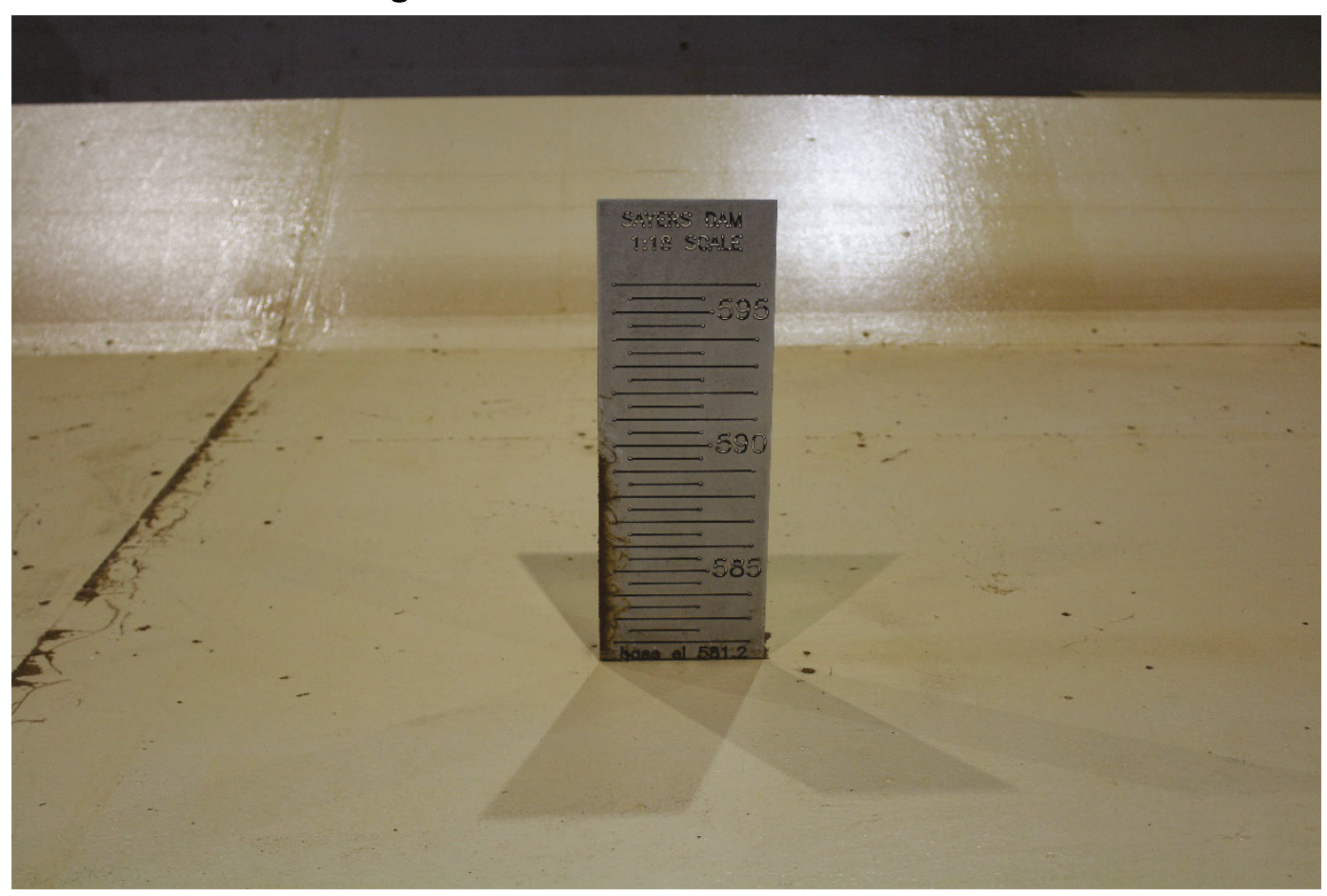

Figure 12. Point gage - exit channel.

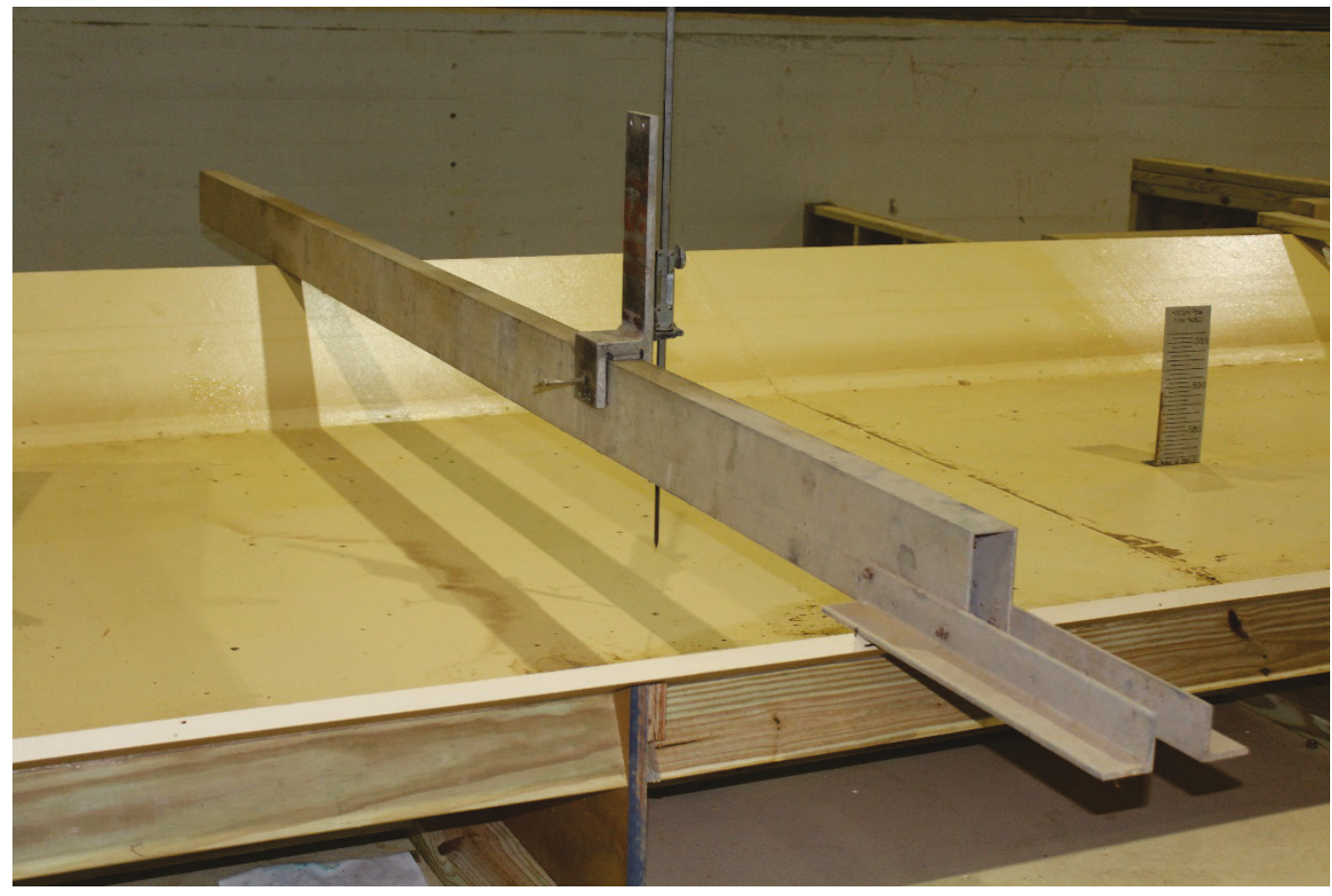


Figure 13. Point gage - exit channel.

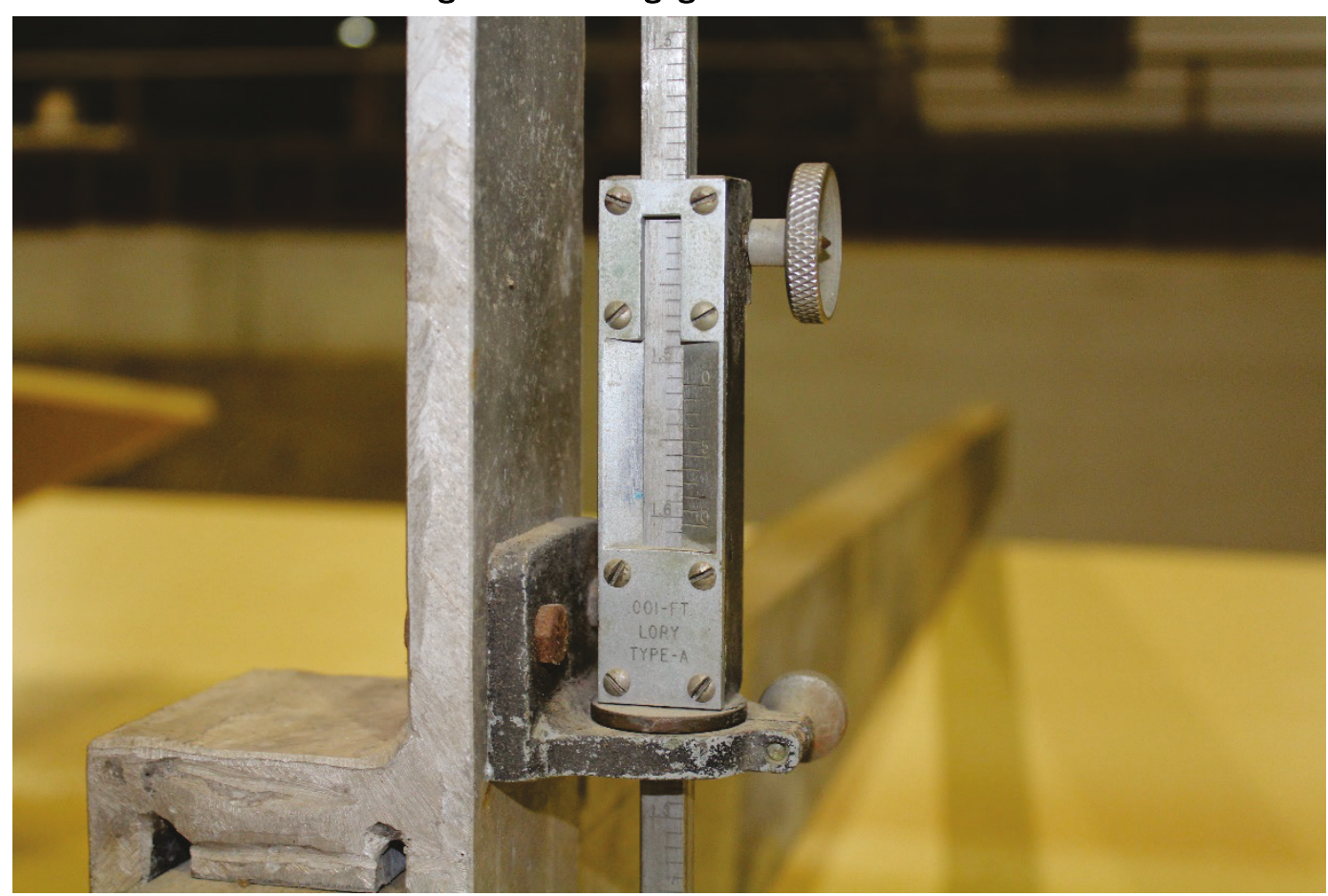

The flow rate through the model was measured by an ultrasonic flowmeter as shown in Figure 14. This flowmeter measures the flow rate using ultrasonic transducers to measure the transit time of ultrasonic pulses into and against the direction of flow. This time difference is directly related to the average velocity of the flow. The analog output of the flowmeter was sampled at 50 hertz to align with the other time-dependent measurements recorded during all experiments.

The flow rate sensors were located on the supply pipe to the physical model behind the head bay. Per the manual of the flowmeter, the sensors had to be at least $10 \mathrm{ft}$ from a 90-degree elbow of the supply pipe and located in a straight section of the supply pipe. Sensors for the flowmeter are shown in Figure 15. 
Figure 14. Ultrasonic flowmeter.

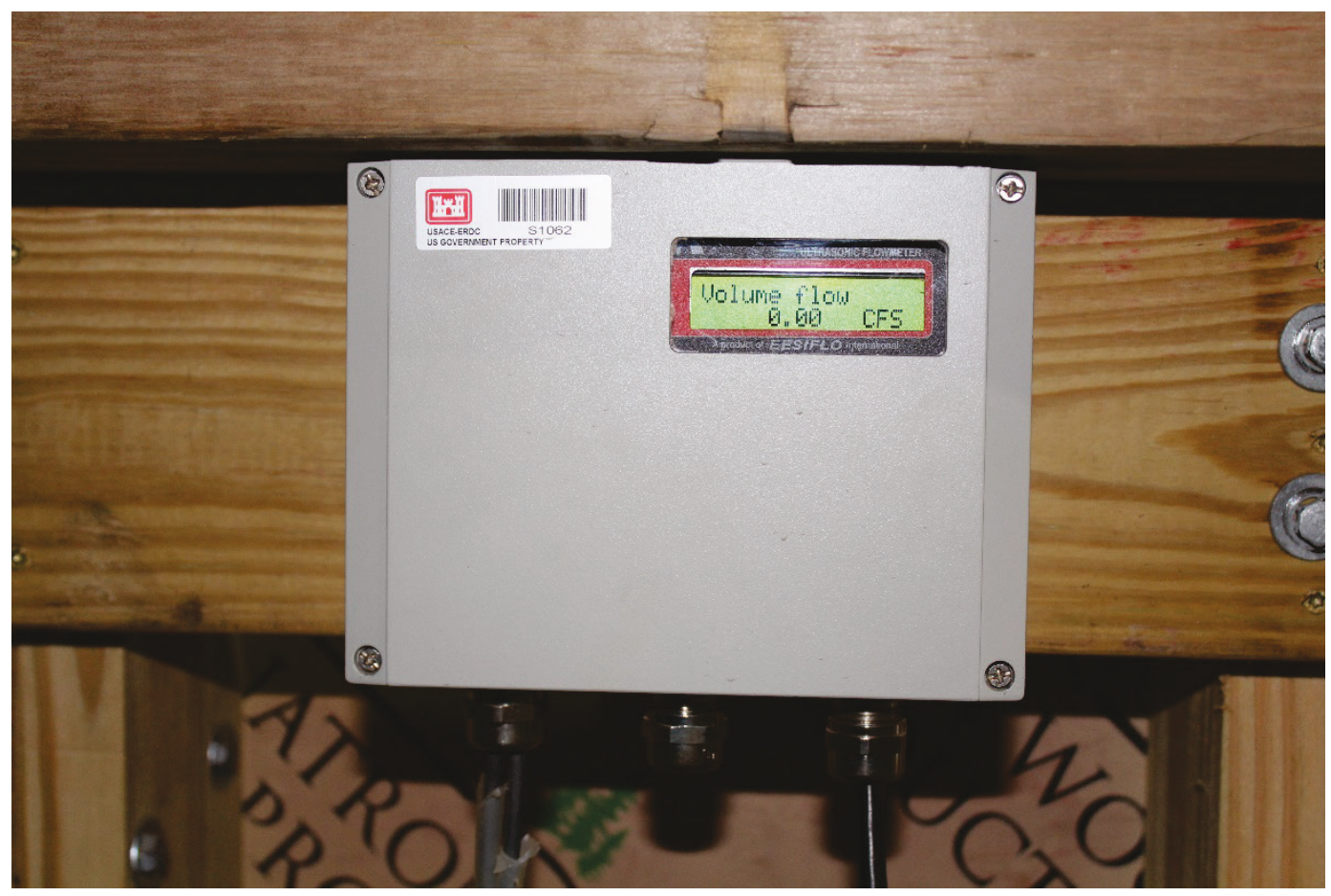

Figure 15. Ultrasonic flowmeter sensors location.

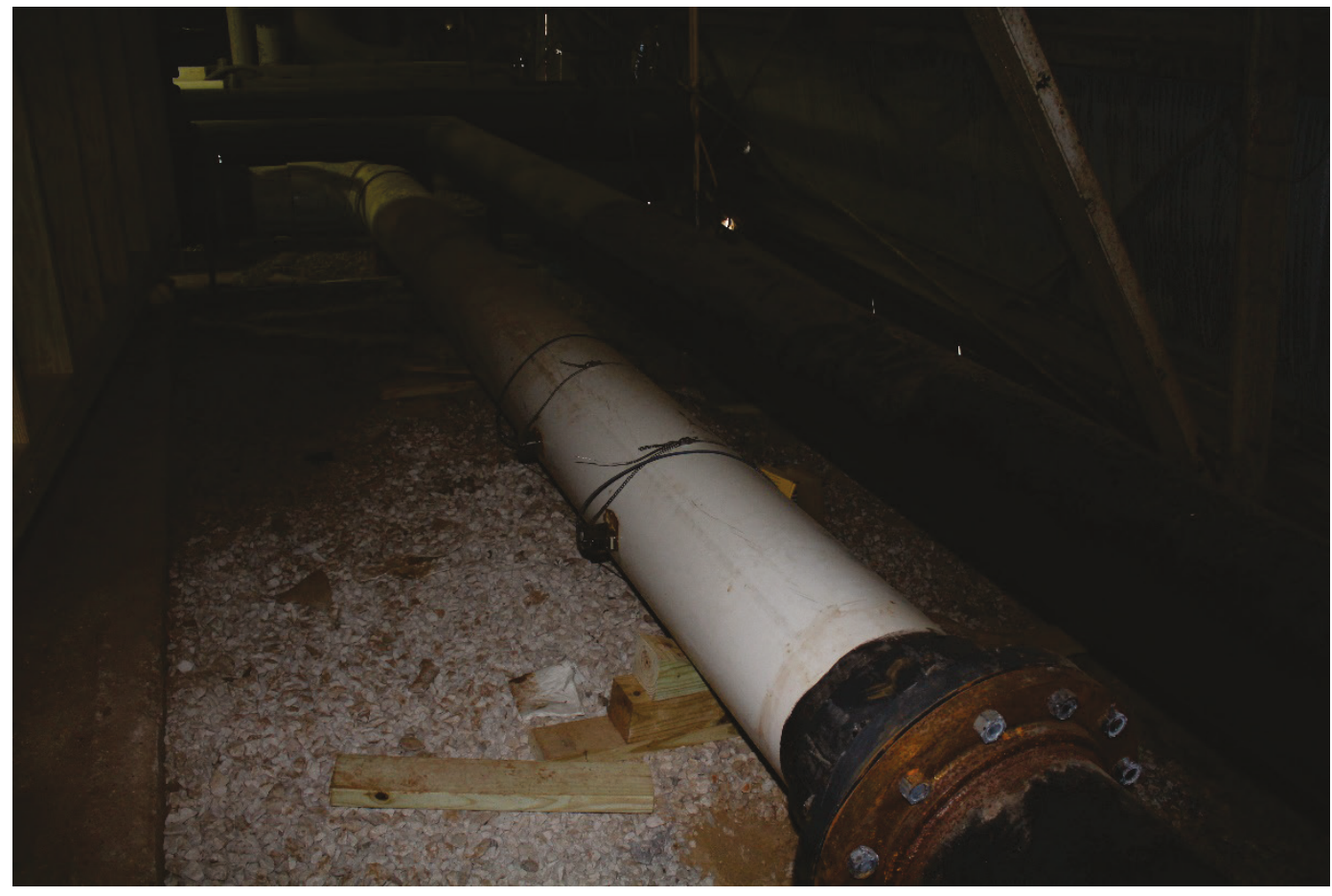




\section{Model Results}

In this chapter, the results of each test are presented. The discussion is broken into two sections: one section for tests with the exit channel as a fixed bed and another section for tests with the exit channel as a movable bed, or riprap.

\subsection{Tests with a fixed bed exit channel}

The first set of tests was completed with the exit channel reproduced with marine grade plywood to represent a fixed bed. An example of the exit channel conditions described can be seen in Figure 16.

Figure 16. View looking downstream of exit channel constructed of marine grade plywood.

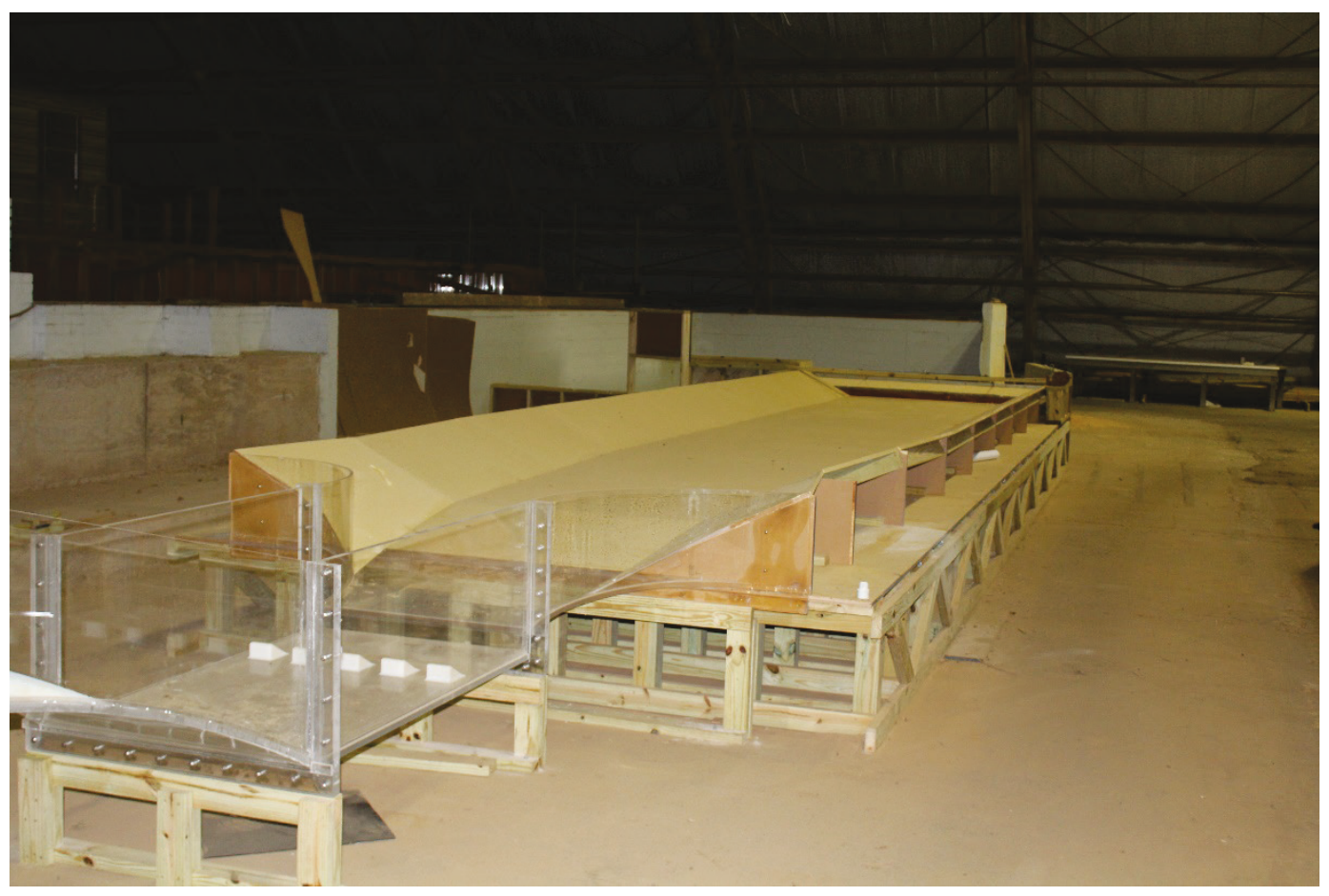

The purpose of these tests was to observe the flow conditions that were present in the model and compare to those observed in the project. These tests were considered part of the model validation.

\subsubsection{Field discharge tests}

In September 2015, NAB conducted a field study where discharge tests were performed to observe flow behavior within the stilling basin (USACE $\mathrm{NAB}$ 2015). For the validation tests, the model was set with a flowrate 
identical to that observed during the field tests, headwater near the level at which the field tests were performed ( $620 \mathrm{ft})$, and a tailwater based off of the tailwater curve provided in the Sayers Dam operations manual (USACE NAB 1996). The gate openings were also set by the discharge curve given in the Sayers Dam operations manual (USACE NAB 1996). The flow conditions observed in the model were similar to those viewed during the field discharge tests (USACE NAB 2015). The model matched the field discharge tests very closely. Table 2 shows the set of field discharge test results completed in the physical model.

Table 2. Model field discharge testing.

\begin{tabular}{|c|c|c|c|c|c|}
\hline Test & $\begin{array}{l}\text { Prototype } \\
\left(\text { cfs*) }^{*}\right.\end{array}$ & $\begin{array}{l}\text { Model } \\
\text { (cfs) }\end{array}$ & $\begin{array}{l}\text { Gate Opening } \\
\text { Elevation (ft) }\end{array}$ & $\begin{array}{l}\text { Headwater } \\
\text { Elevation }(\mathrm{ft})\end{array}$ & $\begin{array}{l}\text { Tailwater } \\
\text { Elevation (ft) }\end{array}$ \\
\hline 1 & 615 & 0.45 & 591.4 & 617.8 & 583.8 \\
\hline 2 & 615 & 0.45 & 591.4 & 617.8 & 583.8 \\
\hline 3 & 615 & 0.45 & 591.4 & 617.8 & 583.2 \\
\hline 4 & 615 & 0.45 & 591.4 & 617.8 & 582.71 \\
\hline 5 & 615 & 0.45 & 591.4 & 617.8 & 584.5 \\
\hline 6 & 615 & 0.45 & 591.4 & 617.8 & 586.5 \\
\hline 7 & 1,000 & 0.73 & 592.25 & 618.3 & 584.7 \\
\hline 8 & 1,500 & 1.09 & 593.5 & 619.5 & 584.9 \\
\hline 9 & 1,500 & 1.09 & 593.5 & 619.5 & 585.8 \\
\hline 10 & 150 & 0.11 & 590.4 & 610 & 581.25 \\
\hline 11 & 615 & 0.45 & 591.4 & 617.5 & 582.9 \\
\hline 12 & 615 & 0.45 & 591.4 & 617.5 & 583.6 \\
\hline 13 & 1,000 & 0.73 & 592.25 & 617.5 & 584 \\
\hline 14 & 1,000 & 0.73 & 592.25 & 617.5 & 584.7 \\
\hline 15 & 1,500 & 1.09 & 593.5 & 619 & 584.9 \\
\hline 16 & 1,500 & 1.09 & 593.5 & 619 & 585.8 \\
\hline 17 & 2,000 & 1.45 & 594.75 & 618 & 585.6 \\
\hline 18 & 2,000 & 1.45 & 594.75 & 618 & 586.8 \\
\hline 19 & 2,500 & 1.82 & 596 & 618 & 586.3 \\
\hline 20 & 2,500 & 1.82 & 596 & 618 & 587.5 \\
\hline 21 & 3,000 & 2.18 & 597.25 & 619.5 & 588.1 \\
\hline 22 & 3,000 & 2.18 & 597.25 & 619.5 & 586.8 \\
\hline 23 & 3,500 & 2.55 & 598.5 & 620.8 & 587.3 \\
\hline
\end{tabular}




\begin{tabular}{|l|l|l|l|l|l|}
\hline Test & $\begin{array}{l}\text { Prototype } \\
\left(\mathrm{cfs}^{*}\right)\end{array}$ & $\begin{array}{l}\text { Model } \\
(\mathrm{cfs})\end{array}$ & $\begin{array}{l}\text { Gate Opening } \\
\text { Elevation }(\mathrm{ft})\end{array}$ & $\begin{array}{l}\text { Headwater } \\
\text { Elevation }(\mathrm{ft})\end{array}$ & $\begin{array}{l}\text { Tailwater } \\
\text { Elevation }(\mathrm{ft})\end{array}$ \\
\hline 24 & 3,500 & 2.55 & 598.5 & 620.8 & 588.6 \\
\hline 25 & 4,000 & 2.91 & 599.7 & 621.4 & 587.7 \\
\hline 26 & 4,000 & 2.91 & 599.7 & 621.4 & 589.1 \\
\hline 27 & 4,500 & 3.27 & 601 & 621.3 & 588.2 \\
\hline 28 & 4,500 & 3.27 & 601 & 621.3 & 589.5 \\
\hline 29 & 5,000 & 3.64 & 602.4 & 621.4 & 589.9 \\
\hline 30 & 6,000 & 4.36 & 605 & 624 & 590.6 \\
\hline 31 & 7,000 & 5.09 & 605 & 631.5 & 591.3 \\
\hline 32 & 8,000 & 5.82 & 605 & 641.25 & 591.9 \\
\hline 33 & 9,300 & 6.76 & 605 & 657 & 592.7 \\
\hline
\end{tabular}

${ }^{*} \mathrm{cfs}=$ cubic feet per second

\subsubsection{Physical model field discharge test observations}

Several observations were made during the physical model field discharge testing. For flows at or below 2,000 cfs, the flow in the stilling basin moved laterally and would not consistently stay to one side or the other. For flows above 2,000 cfs, the flow was more uniform with horizontal eddies on each side of the stilling basin. During all tests, onehalf in. to two-and-one-half in. diameter gravel pieces were placed in the bottom of the stilling basin. This would scale to 9 in. to 45 in. rock in the prototype. The main purpose was to see how each flow would affect the gravel on the bottom of the basin. At flows starting at $615 \mathrm{cfs}$, the gravel and debris in the water would begin to swirl revealing turbulent flows on the bottom of the basin even during low flow conditions. This also demonstrates why the concrete basin is currently being damaged by riprap entrapment. The gravel placed within the stilling basin did not begin flushing out of the basin until a discharge of $6,000 \mathrm{cfs}$ or Test 30 . By Test 32 with 8,000 cfs, all gravel placed in the stilling basin was flushed into the exit channel. However, periodically flushing the stilling basin in this manner is not feasible because the project release has never experienced a discharge of 8,000 cfs as it would also cause significant downstream flooding. Also, for Test 33, the outlet works stilling basin design discharge of $9,300 \mathrm{cfs}$, the head bay upper reservoir elevation reached $657 \mathrm{ft}$. The model therefore accurately duplicated design outflow projections with the pool at spillway crest. Notes for each test are included in the Appendix of this report. 


\subsubsection{Summer and winter pool elevation tests observations}

The next set of tests was conducted looking at the summer and winter pool elevations for selected discharges and documenting the flow conditions and riprap movement within the stilling basin. Also, during these tests, riprap was placed on the lower concrete apron to determine if certain flows could possibly pull riprap into the stilling basin from the apron. Table 3 shows the tests for summer and winter pool elevations. The tests were performed for discharges from 1,000 to $3,500 \mathrm{cfs}$ since historical records show the outlet works has only reached $3,500 \mathrm{cfs}$ release twice since 2000.

Table 3. Summer and winter pool testing.

\begin{tabular}{|l|l|l|l|l|l|}
\hline Test & $\begin{array}{l}\text { Prototype } \\
\text { (cfs) }\end{array}$ & $\begin{array}{l}\text { Model } \\
\text { (cfs) }\end{array}$ & $\begin{array}{l}\text { Gate Opening Elevation } \\
\text { (ft) }\end{array}$ & $\begin{array}{l}\text { Headwater Elevation } \\
\text { (ft) }\end{array}$ & $\begin{array}{l}\text { Tailwater Elevation } \\
\text { (ft) }\end{array}$ \\
\hline 34 & 1,000 & 0.73 & 591.8 & 630 & 584.7 \\
\hline 35 & 1,000 & 0.73 & 591.8 & 630 & 584 \\
\hline 36 & 1,000 & 0.73 & 592.5 & 610 & 584 \\
\hline 37 & 1,000 & 0.73 & 592.5 & 610 & 584.7 \\
\hline 38 & 3,500 & 2.55 & 597.2 & 630 & 587.3 \\
\hline 39 & 3,500 & 2.55 & 597.2 & 630 & 588.6 \\
\hline 40 & 3,500 & 2.55 & 602 & 610 & 587.3 \\
\hline 41 & 1,500 & 1.09 & 592.8 & 630 & 584.9 \\
\hline 42 & 1,500 & 1.09 & 592.8 & 630 & 585.8 \\
\hline 43 & 1,500 & 1.09 & 592.8 left/ 592.3 right & 630 & 585.8 \\
\hline 44 & 1,500 & 1.09 & 594.4 & 610 & 585.8 \\
\hline 45 & 1,500 & 1.09 & 594.4 & 610 & 584.9 \\
\hline 46 & 3,500 & 2.55 & 596.6 & 630 & 588.6 \\
\hline 47 & 3,500 & 2.55 & 602 & 612 & 588.6 \\
\hline 48 & 2,000 & 1.45 & 594 & 630 & 586.8 \\
\hline 49 & 2,000 & 1.45 & 594 & 630 & 586.8 \\
\hline 50 & 2,000 & 1.45 & 594 & 630 & 586.8 \\
\hline 51 & 3,000 & 2.18 & 595.9 & 530 & 586.1 \\
\hline 52 & 3,000 & 2.18 & 595.9 & & \\
\hline
\end{tabular}


With the rock placed on the lower apron, several items of interest were observed. If the gates in the gate structure are at different elevations, a large horizontal eddy forms within the stilling basin. This eddy does have the potential to move large rock from the concrete apron upstream into the stilling basin. However, riprap that was placed toward the end of the concrete apron as well on the riprap apron never moved upstream, only downstream. The fixed-bed tests with the summer and winter pool elevations where riprap was placed at varying locations downstream from the stilling basin did not show any riprap being pulled back upstream into the basin. Subsequently, moveable bed tests were conducted to see if any changes occurred.

\subsubsection{Upper approach channel riprap observations}

Next, riprap was placed on the upstream approach channel to determine if riprap could be pulled through the gate structure and land in the stilling basin. Tests were performed from 150 to 4,000 cfs all with a low tailwater elevation and are listed in Table 4. Each test was run for a period of 30 minutes.

Table 4. Upstream rock movement testing.

\begin{tabular}{|l|l|l|l|l|l|}
\hline Test & $\begin{array}{l}\text { Prototype } \\
\text { (cfs) }\end{array}$ & $\begin{array}{l}\text { Model } \\
\text { (cfs) }\end{array}$ & $\begin{array}{l}\text { Gate Opening } \\
\text { Elevation (ft) }\end{array}$ & $\begin{array}{l}\text { Headwater } \\
\text { Elevation (ft) }\end{array}$ & $\begin{array}{l}\text { Tailwater Elevation } \\
\text { (ft) }\end{array}$ \\
\hline 53 & 150 & 0.11 & 590.2 & 630 & Low Tailwater \\
\hline 54 & 615 & 0.45 & 591.15 & 630 & Low Tailwater \\
\hline 55 & 1,000 & 0.73 & 591.85 & 630 & Low Tailwater \\
\hline 56 & 1,500 & 1.09 & 592.9 & 630 & Low Tailwater \\
\hline 57 & 2,000 & 1.45 & 593.9 & 630 & Low Tailwater \\
\hline 58 & 2,500 & 1.82 & 595 & 630 & Low Tailwater \\
\hline 59 & 3,000 & 2.18 & 596 & 630 & Low Tailwater \\
\hline 60 & 3,500 & 2.55 & 597 & 630 & Low Tailwater \\
\hline 61 & 4,000 & 2.91 & 598.1 & 630 & Low Tailwater \\
\hline 62 & 150 & 0.11 & 590.3 & 610 & Low Tailwater \\
\hline 63 & 615 & 0.45 & 591.7 & 610 & Low Tailwater \\
\hline 64 & 1,000 & 0.73 & 592.7 & 610 & Low Tailwater \\
\hline 65 & 1,500 & 1.09 & 594.25 & 610 & Low Tailwater \\
\hline 66 & 2,000 & 1.45 & 596.05 & 610 & Low Tailwater \\
\hline 67 & 2,500 & 1.82 & 597.75 & 610 & Low Tailwater \\
\hline
\end{tabular}




\begin{tabular}{|l|l|l|l|l|l|}
\hline Test & $\begin{array}{l}\text { Prototype } \\
\text { (cfs) }\end{array}$ & $\begin{array}{l}\text { Model } \\
\text { (cfs) }\end{array}$ & $\begin{array}{l}\text { Gate Opening } \\
\text { Elevation (ft) }\end{array}$ & $\begin{array}{l}\text { Headwater } \\
\text { Elevation }(\mathrm{ft})\end{array}$ & $\begin{array}{l}\text { Tailwater Elevation } \\
\text { (ft) }\end{array}$ \\
\hline 68 & 3,000 & 2.18 & 600 & 610 & Low Tailwater \\
\hline 69 & 3,500 & 2.55 & 602.3 & 610 & Low Tailwater \\
\hline 70 & 4,000 & 2.91 & 605 & 610 & Low Tailwater \\
\hline 71 & 2,500 & 1.82 & 597.75 & 610 & Low Tailwater \\
\hline 72 & 3,000 & 2.18 & 600 & 610 & Low Tailwater \\
\hline 73 & 3,500 & 2.55 & 602.3 & 610 & Low Tailwater \\
\hline 74 & 4,000 & 2.91 & 605 & 612 & Low Tailwater \\
\hline
\end{tabular}

As the tests were being performed, a few pieces of riprap were pulled through the gate structure on tests 68 and 69. After further investigation, due to the low headwater elevation and the topography of the approach channel, the velocity of the flow on the left side of the head bay was greater than the velocity of the flow on the right side. The supply pipe for the model was causing this effect. To produce a better flow distribution, a second layer of baffle material was installed to the baffle wall just on the left side to counter the supply pipe outflow. The tests were repeated, and no riprap was pulled through the gate structure.

\subsection{Sayers outlet works riprap design}

The Sayers outlet works has riprap protection of varying sizes in the approach and exit channels (USACE NAB 1969).

\subsubsection{Upstream riprap protection}

The submerged approach channel has a trapezoidal shape with $1 \mathrm{~V}$ on $2 \mathrm{H}$ side slopes and a bottom width of $30 \mathrm{ft}$. The left side slope has riprap beginning at approximately station (sta) $15+30 \mathrm{C}$ and is protected with a 12 in. blanket thickness between the invert and elevation (el) 607 and with an 18 in. blanket thickness above el 607. The protection goes downstream and transitions into the approach training wall and dam embankment. The right side slope protection begins at sta $16+$ ooC and has the same blanket thickness design as the left side slope protection and transitions to the training wall and dam embankment similarly. 


\subsubsection{Downstream riprap protection}

The downstream channel also has a trapezoidal shape with $1 \mathrm{~V}$ on $2 \mathrm{H}$ side slopes and a variable bottom width. The invert and sides slopes have a 36inch blanket thickness from sta $24+41 \mathrm{C}$ to $25+00 \mathrm{C}$. The side slopes are protected with an $18 \mathrm{in}$. blanket thickness from sta $25+\mathrm{OoC}$ downstream to the end of the exit channel.

\subsubsection{Riprap for 18 in. thickness}

The specifications for the 18 in. blanket thickness were furnished by NAB. The information furnished to the contractor when the project was being constructed indicated "The stone shall weigh no more than 640 pounds for single pieces, shall be block shaped and reasonably well graded. In no case will the maximum dimension of any stone be greater than 3 times the minimum dimension. The average stone shall weigh 120 to 200 pounds and the minimum size stone shall not weigh less than 20 pounds." (USACE NAB 1969)

\subsubsection{Riprap for 24 in. thickness}

The specifications for the $24 \mathrm{in}$. blanket thickness were also furnished by NAB. It stated "Stone shall weigh not more than 1,400 pounds for single pieces, shall be block shaped and reasonably well graded. In no case will the maximum dimension of any stone be greater than 3 times the minimum dimension. The average stone shall weigh 300 to 400 pounds and the minimum size stone shall not weigh less than 20 pounds." (USACE NAB 1969)

\subsubsection{Riprap for 36 in. blanket thickness}

The gradation for the $36 \mathrm{in}$. blanket thickness was not furnished, so one was developed based on the criteria used for the 18 and 24 in. blanket thicknesses. The $\mathrm{D}_{100}(\max )$ size stone for the 18 and $24 \mathrm{in}$. blanket thicknesses was determined to be 1.3 times the blanket thickness. The $\mathrm{D}_{50}(\max )$ size stone for the 18 and 24 in. blanket thicknesses was determined to be 0.83 times the blanket thickness. The minimum weight stone was kept the same as the $24 \mathrm{in}$. blanket at $20 \mathrm{lb}$. 


\subsubsection{Riprap gradation}

The riprap weight is converted to an equivalent spherical diameter by the following equation:

$$
\mathrm{D} 50=\left\{\frac{6 * \mathrm{~W} 50}{\pi * \gamma S}\right\}^{\frac{1}{3}}
$$

where:

$$
\begin{aligned}
\mathrm{W}_{50}= & \text { weight of stone that represents the size where } 50 \% \text { of the total } \\
& \text { weight of material containing stone weighs less than this stone } \\
\gamma \mathrm{S}= & \text { specific stone weight, } \frac{l b}{f t 3} \\
\mathrm{D}_{50}= & \text { spherical diameter of stone having the same weight as W50. }
\end{aligned}
$$

For example, the equivalent diameter of a stone weighing 640 pounds (lb) is $1.95 \mathrm{ft}$ or $23.4 \mathrm{in}$. This would equate to a $1.3 \mathrm{in}$. stone in the physical model.

The gradations used for the initial tests are shown in Figure 17 to Figure 19. The gradation for the $18 \mathrm{in}$. blanket thickness consisted of a mixture containing $40 \%$ stones weighing 15.4 to $123 \mathrm{lb}$ (7.4 to $13.5 \mathrm{in}$.) and $60 \%$ stones weighing 123 to $291 \mathrm{lb}$ ( 13.5 to $18 \mathrm{in}$.). The gradation for the $36 \mathrm{in}$. blanket thickness consisted of a mixture containing $40 \%$ stones weighing 36.4 to $983 \mathrm{lb}$ ( 9 to $27 \mathrm{in}$ ), $30 \%$ stones weighing 983 to $1,562 \mathrm{lb}$ (27 to $31.5 \mathrm{in}$.), $10 \%$ stones weighing 1,562 to $2,331 \mathrm{lb}$ (31.5 to $36 \mathrm{in}$.), and $20 \%$ stones weighing 2,331 to $4,553 \mathrm{lb}$ (36 to $45 \mathrm{in}$.). 
Figure 17. 18 in. blanket thickness gradation.

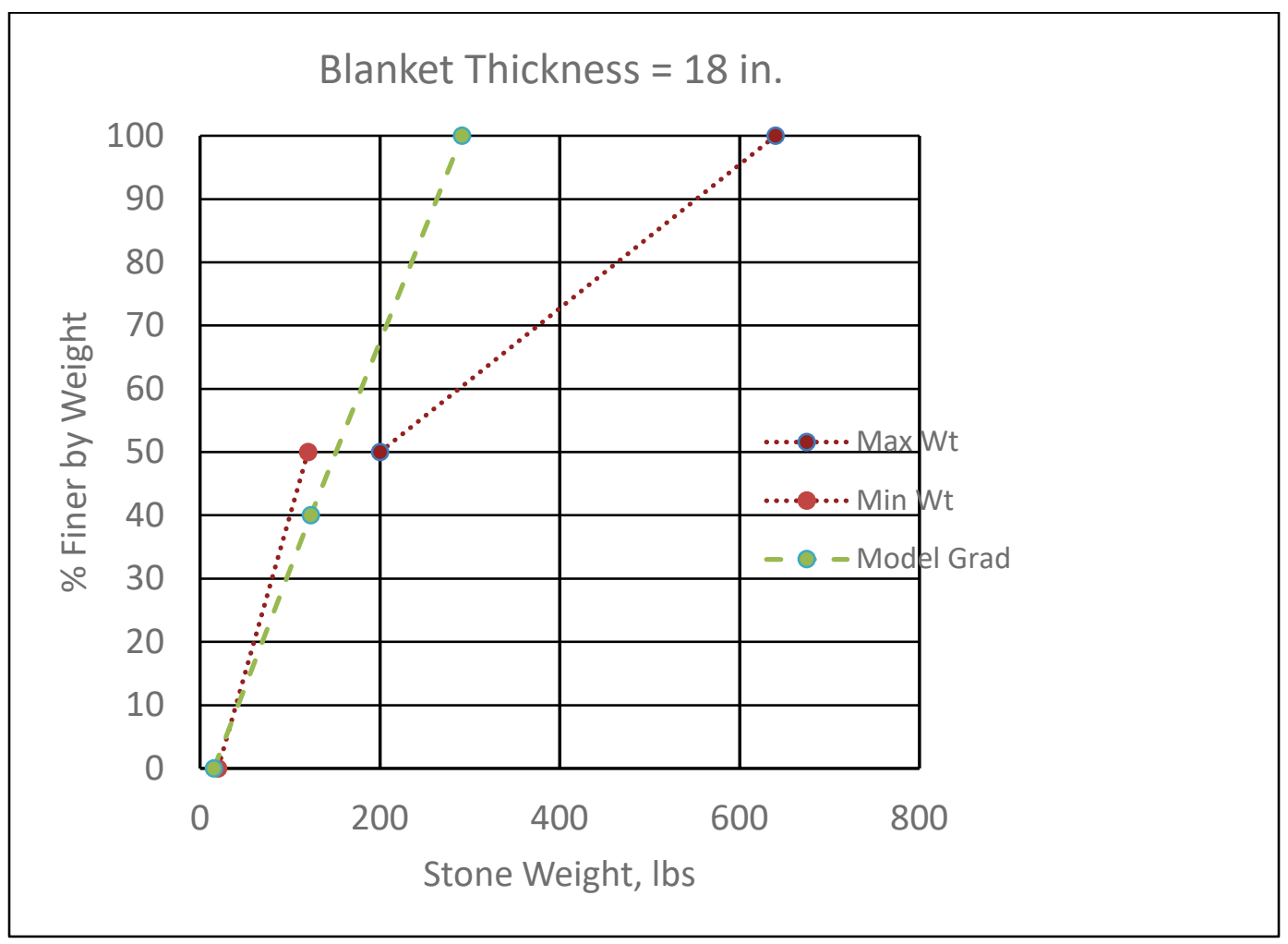

Figure 18. 24 in. blanket thickness gradation.

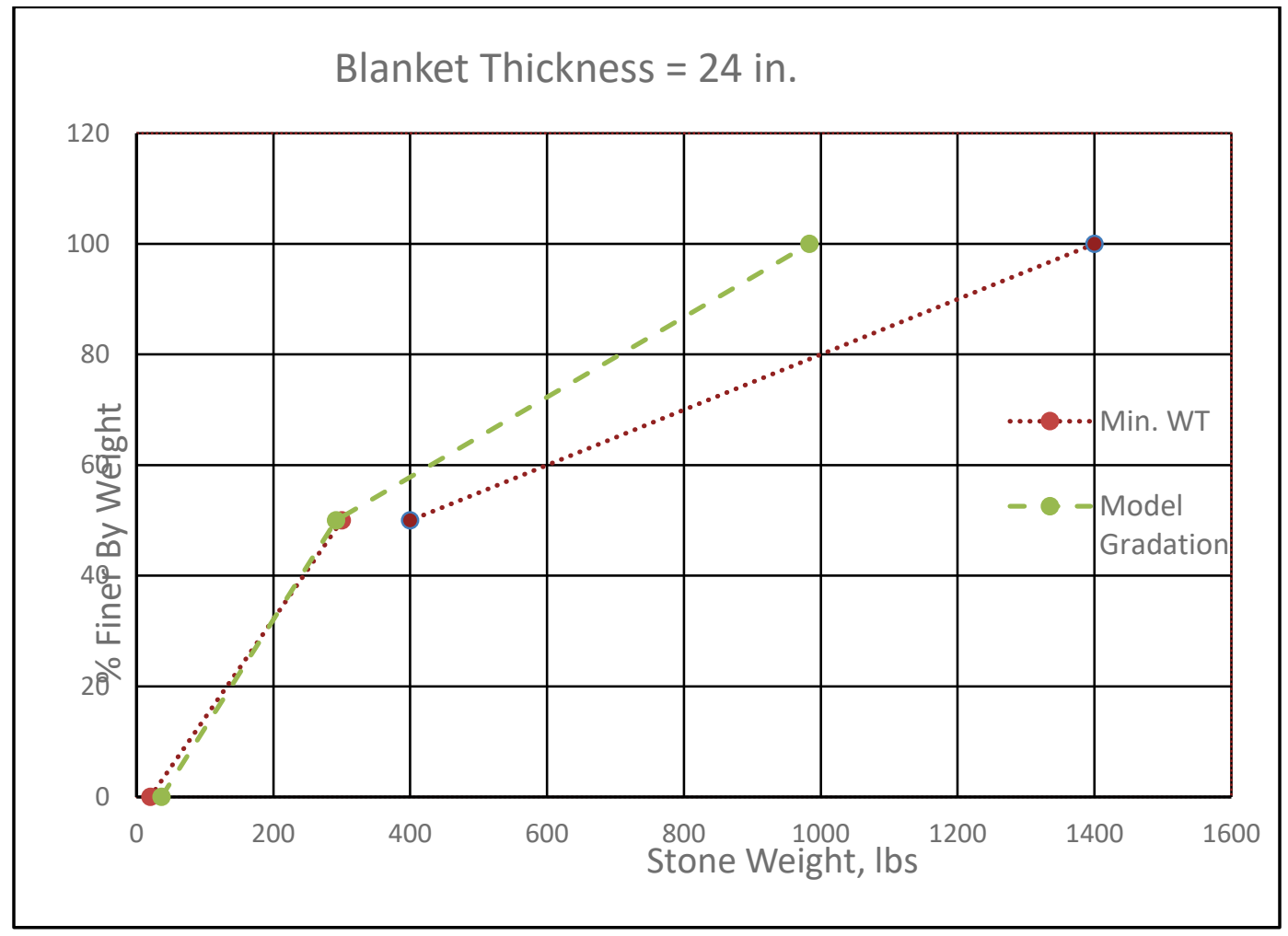


Figure 19. 36 in. blanket thickness gradation.

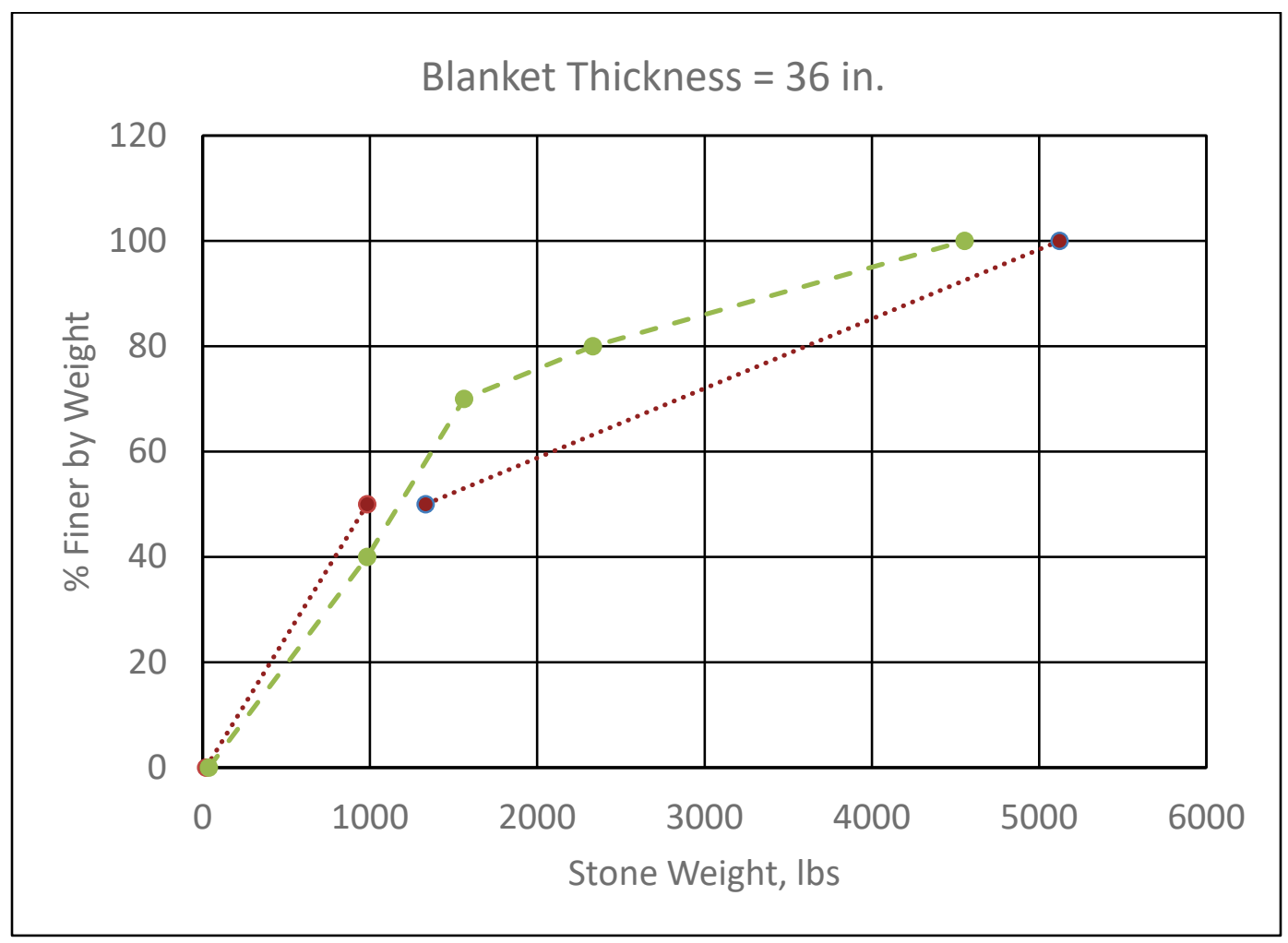

\subsection{Tests with a movable bed exit channel}

Tests resumed once the $36 \mathrm{in}$. riprap blanket thickness and $18 \mathrm{in.} \mathrm{riprap}$ blanket thickness were installed in the exit channel. A $200 \mathrm{ft}$ length of the exit channel was converted to a movable bed configuration. This configuration can be seen in Figure 20 and Figure 21. The 36 in. riprap blanket thickness was installed in the model for $60 \mathrm{ft}$ down from the stilling basin on the side and bottom of the exit channel as the construction drawings portray. Downstream of this section, the $18 \mathrm{in}$. riprap blanket thickness was installed only on the sides, again following the construction drawings. Table 5 lists the tests that were completed using the 36 in. riprap blanket thickness. For all tests, the water was never turbulent enough for riprap to be entrained and moved upstream into the stilling basin. 
Figure 20. Movable bed exit channel with a discharge of $2,000 \mathrm{cfs}$.

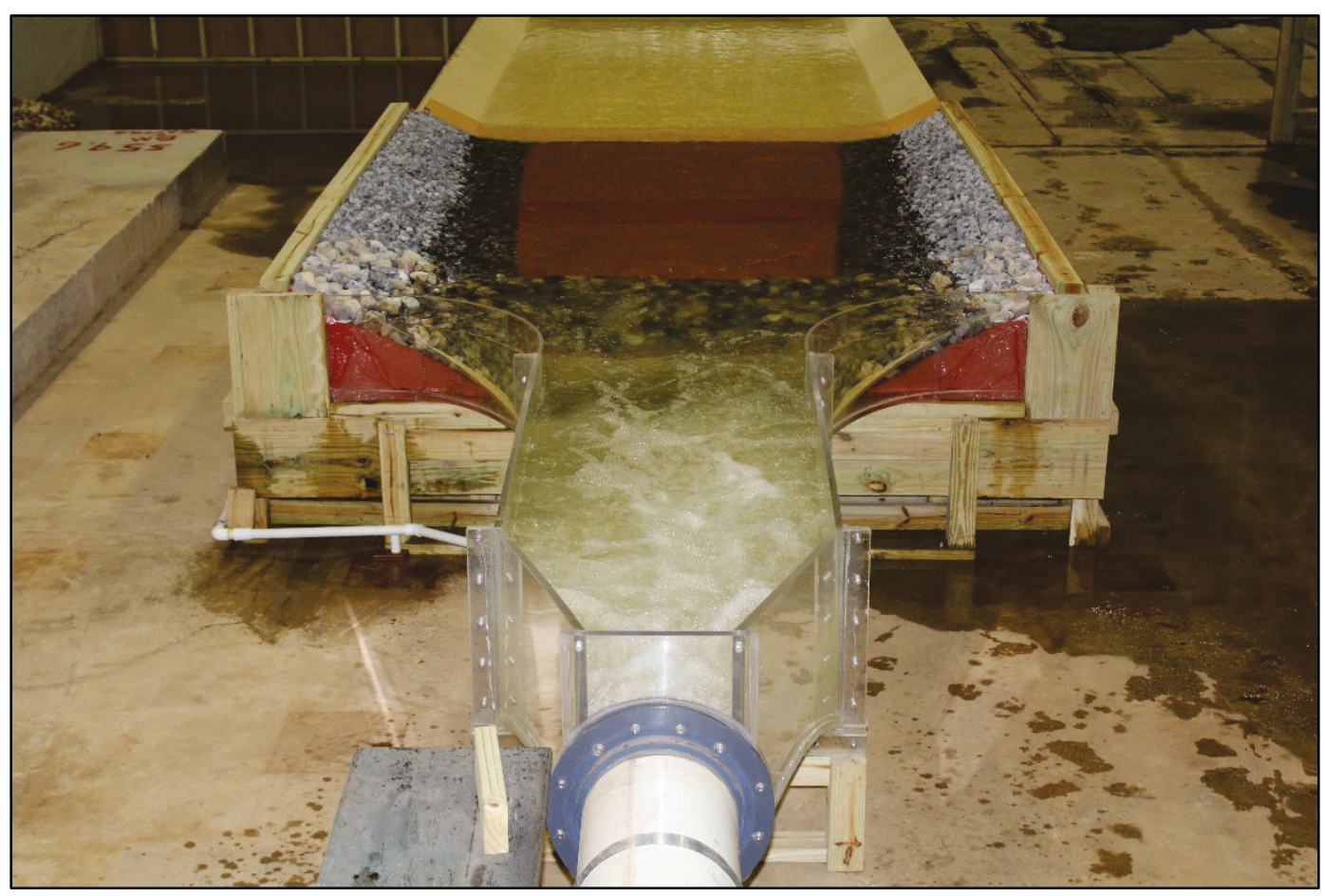


Figure 21. Dry bed view looking upstream of movable bed exit channel.

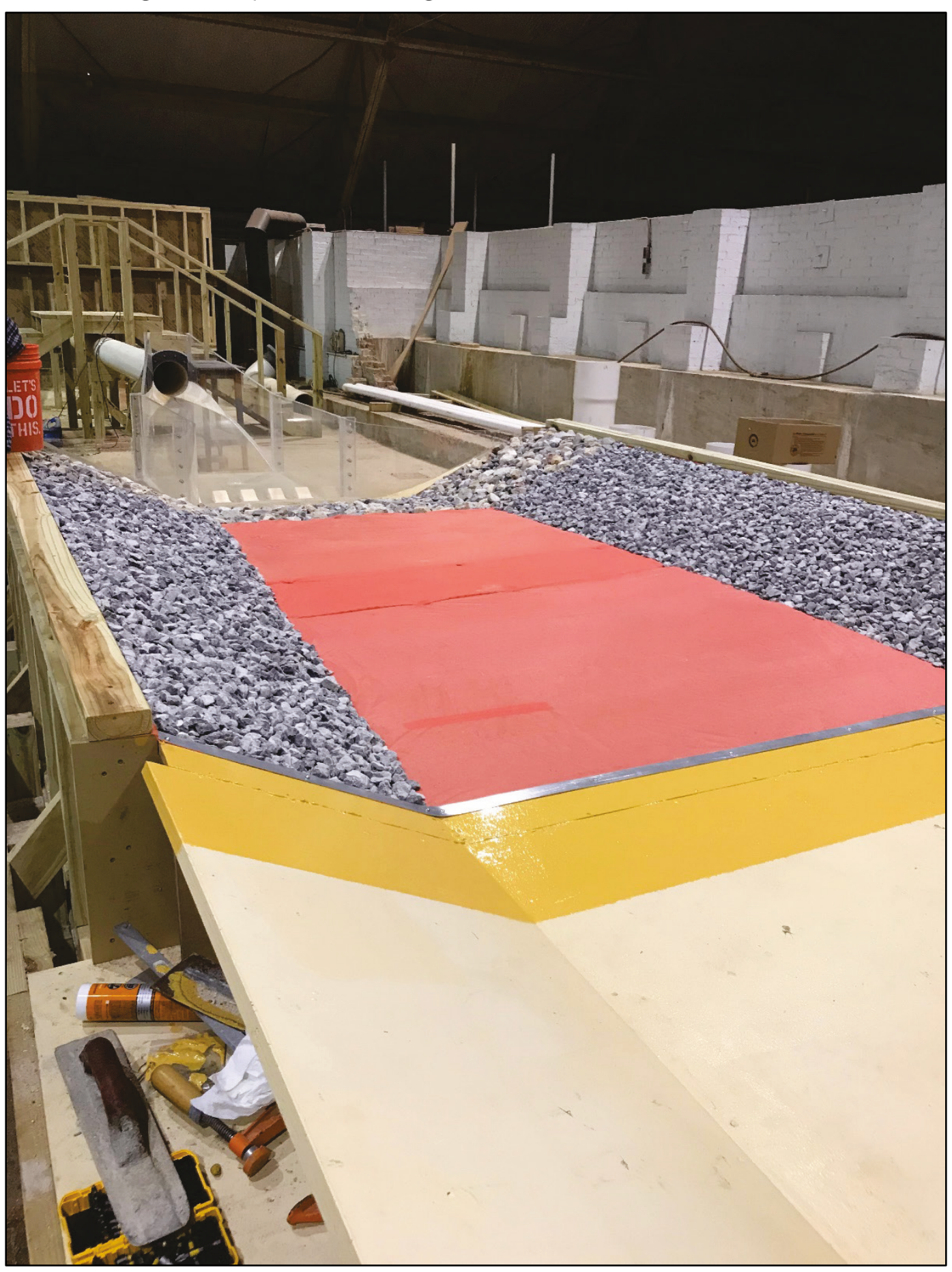


Table 5. Removable bed tests with 36 in. riprap blanket thickness.

\begin{tabular}{|c|c|c|c|c|c|}
\hline Test & \begin{tabular}{|l} 
Prototype \\
(cfs)
\end{tabular} & \begin{tabular}{|l} 
Model \\
(cfs)
\end{tabular} & $\begin{array}{l}\text { Gate Opening } \\
\text { Elevation (ft) }\end{array}$ & $\begin{array}{l}\text { Headwater Elevation } \\
\text { (ft) }\end{array}$ & $\begin{array}{l}\text { Tailwater Elevation } \\
\text { (ft) }\end{array}$ \\
\hline 75 & 150 & 0.11 & 590.3 & 630 & 581.8 \\
\hline 76 & 150 & 0.11 & 590.3 & 630 & 581.25 \\
\hline 77 & 615 & 0.45 & 591.25 & 630 & 583.6 \\
\hline 78 & 615 & 0.45 & 591.25 & 630 & 582.9 \\
\hline 79 & 1,000 & 0.73 & 591.8 & 630 & 584.7 \\
\hline 80 & 1,000 & 0.73 & 591.8 & 630 & 584 \\
\hline 81 & 1,500 & 1.09 & 592.8 & 630 & 585.8 \\
\hline 82 & 1,500 & 1.09 & 592.8 & 630 & 584.9 \\
\hline 83 & 2,000 & 1.45 & 593.9 & 630 & 586.8 \\
\hline 84 & 2,000 & 1.45 & 593.9 & 630 & 585.6 \\
\hline 85 & 2,500 & 1.82 & 595 & 630 & 587.5 \\
\hline 86 & 2,500 & 1.82 & 595 & 630 & 586.3 \\
\hline 87 & 3,000 & 2.18 & 596 & 630 & 588.1 \\
\hline 88 & 3,000 & 2.18 & 596 & 630 & 586.8 \\
\hline 89 & 3,500 & 2.55 & 597 & 630 & 588.6 \\
\hline 90 & 3,500 & 2.55 & 597 & 630 & 587.3 \\
\hline 91 & 4,000 & 2.91 & 598.1 & 630 & 589.1 \\
\hline 92 & 4,000 & 2.91 & 598.1 & 630 & 587.7 \\
\hline 93 & 4,500 & 3.27 & 599.15 & 630 & 589.5 \\
\hline 94 & 4,500 & 3.27 & 599.15 & 630 & 588.2 \\
\hline 95 & 5,000 & 3.64 & 600.2 & 630 & 589.9 \\
\hline 96 & 5,000 & 3.64 & 600.2 & 630 & 588.5 \\
\hline 97 & 5,000 & 3.64 & 605 & 618 & 588.5 \\
\hline 98 & 5,000 & 3.64 & 605 & 618 & 589.9 \\
\hline 99 & 4,500 & 3.27 & 605 & 615 & 588.2 \\
\hline 100 & 4,500 & 3.27 & 605 & 615 & 589.5 \\
\hline 101 & 4,000 & 2.91 & 612 & 612 & 587.7 \\
\hline 102 & 1,500 & 1.09 & L592.8/R592.2 & 630 & 585.8 \\
\hline
\end{tabular}


Since none of the 36 in. riprap moved into the stilling basin during testing, the gradation for the 36 in. riprap blanket thickness area was re-examined. As already mentioned in Section 3.2.5, the 36 in. blanket thickness specifications were interpolated from the 18 and 24 in. blanket thickness specifications provided by NAB. Another approach to determine the size for the $36 \mathrm{in}$. blanket thickness was used and was based on design guidance (HQUSACE 1980) (WES 1977). This method involves calculating the $\mathrm{D}_{50}$ size stone by using the following equation:

$$
V=C\left(\frac{2 g(\gamma \mathrm{s}-\gamma \mathrm{w})}{\gamma \mathrm{w}}\right)^{\frac{1}{2}}(\mathrm{D} 50)^{\frac{1}{2}}
$$

where $\mathrm{V}$ is the velocity at the end sill, $\gamma_{s}$ is the specific stone weight, $\gamma_{w}$ is the specific weight of water, $\mathrm{D}_{50}$ spherical diameter of stone having the same weight as $\mathrm{W}_{50}, \mathrm{C}$ is the Isbash constant, and $g$ is the acceleration due to gravity. The average velocity for the design discharge was computed knowing the discharge, tailwater, and basin dimensions, and D50 was determined from the equation above. Next, $\mathrm{W}_{50}$ was calculated using the equation in section 3.2.6.

A $W_{50}$ minimum of $96 \mathrm{lb}$ was computed. Using the tables (HQUSACE 1994), a 21 in. to 24 in. riprap blanket thickness could be used. Since this thickness was close to the gradation used for the 18 in. blanket thickness, the 36 in. blanket thickness was replaced with the 18 in. riprap blanket thickness. The premise being if this riprap did not move during the tests, the existing 36 in. blanket thickness at the project would not move. Also, the specifications for the 18 in. blanket thickness riprap was provided by NAB. Figure 22 and Figure 23 show where the 36 in. blanket thickness zone was replaced with 18 in. blanket thickness. 
Figure 22. 36 in. blanket thickness replaced with 18 in. blanket thickness looking downstream.

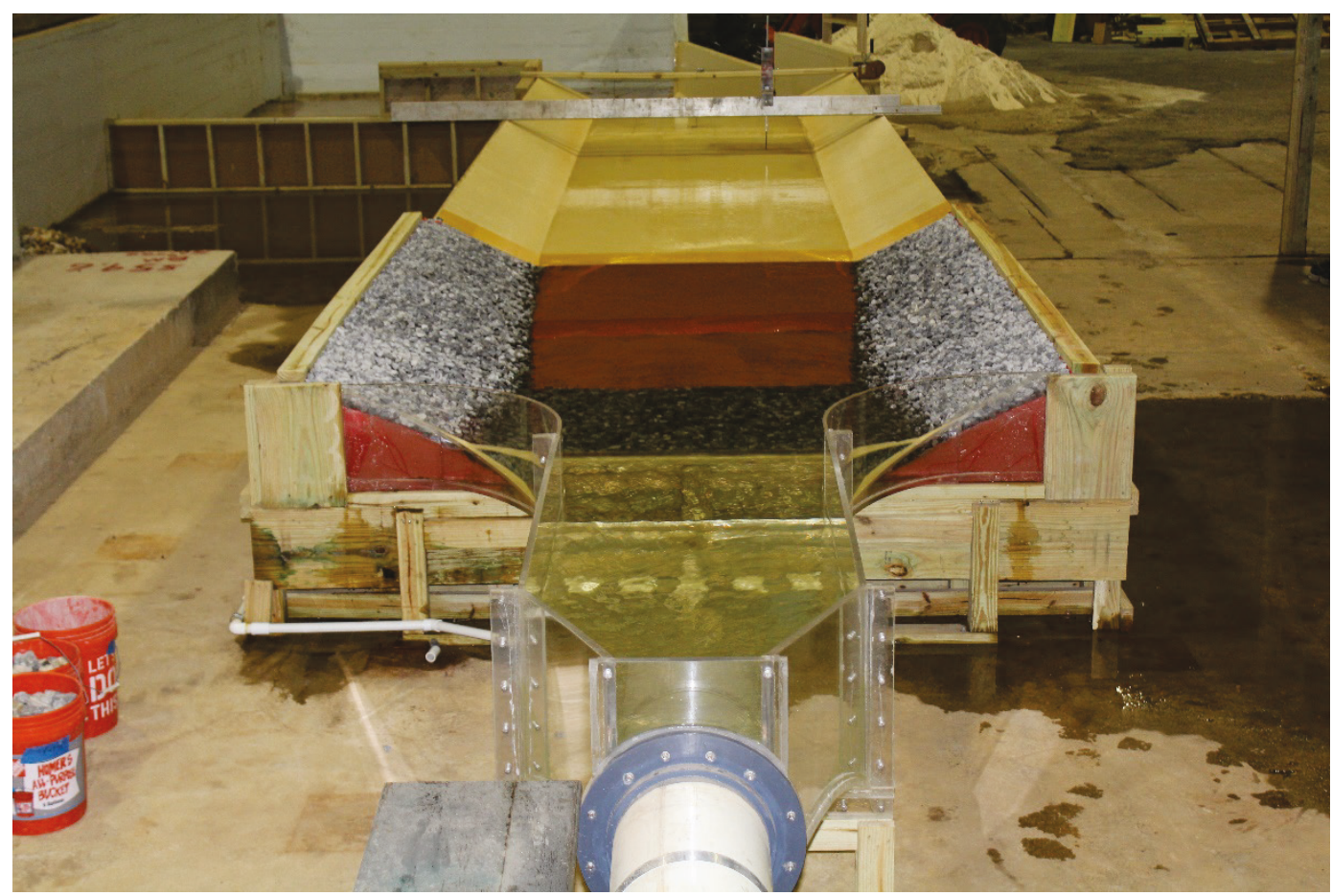

Figure 23. Cross view of 36 in. blanket thickness replaced with 18 in. blanket thickness.

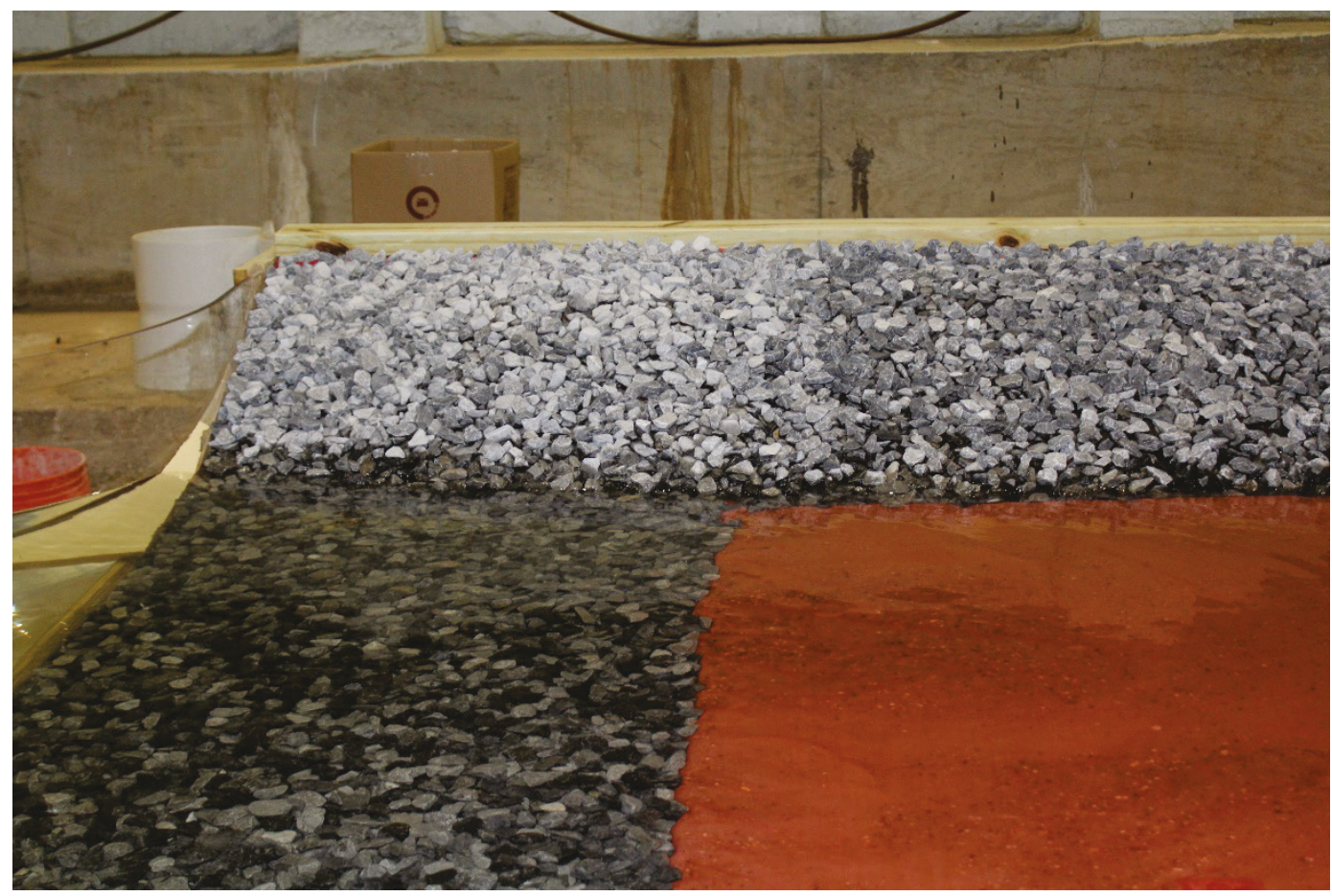

Once the $36 \mathrm{in}$. blanket thickness was replaced with the $18 \mathrm{in.} \mathrm{riprap,}$ additional tests were performed and are listed in Table 6. 
Table 6. Movable bed tests with 18 in. blanket thickness in 36 in. zone.

\begin{tabular}{|c|c|c|c|c|c|}
\hline Test & Prototype (cfs) & Model (cfs) & $\begin{array}{l}\text { Gate Opening Elevation } \\
\text { (ft) }\end{array}$ & $\begin{array}{l}\text { Headwater } \\
\text { Elevation } \\
\text { (ft) }\end{array}$ & Tailwater Elevation (ft) \\
\hline 103 & 1,500 & 1.09 & 593 & 630 & 585.8 \\
\hline 104 & 2,500 & 1.82 & 595 & 630 & 587.5 \\
\hline 105 & 2,500 & 1.82 & 595 & 630 & 588.5 \\
\hline 106 & 2,500 & 1.82 & 595 & 630 & 589.5 \\
\hline 107 & 3,500 & 2.55 & 597 & 630 & 588.6 \\
\hline 108 & 3,500 & 2.55 & 597 & 630 & 589.6 \\
\hline 109 & 3,500 & 2.55 & 597 & 630 & 590.6 \\
\hline 110 & 3,500 & 2.55 & 597 & 630 & 587.3 \\
\hline 111 & 3,500 & 2.55 & 597 & 630 & 586.3 \\
\hline 112 & 5,000 & 3.64 & 600.1 & 630 & 589.9 \\
\hline 113 & 150 & 0.11 & 590.3 & 630 & 581.8 \\
\hline 114 & 615 & 0.45 & 591.25 & 630 & 583.6 \\
\hline 115 & 1,000 & 0.73 & 591.8 & 630 & 584.7 \\
\hline 116 & $1,000 / 2,000$ & $0.73 / 1.45$ & 591.8/594.75 (1 gate) & 630 & 584.7 \\
\hline 117 & 1,000 inc. & $0.73 / 1.46$ & 591.8 & 630 & 584.7 \\
\hline 118 & $3,500 / 2,000$ & $2.55 / 1.45$ & $597 / 594.75$ (1 gate) & 642 & 584.7 \\
\hline 119 & 2,000 & 1.45 & 594.75 (close 1 gate) & 630 & 585.6 \\
\hline 120 & 2,000 & 1.45 & 1 gate only at 597.8 & 630 & 585.6 \\
\hline 121 & 3,000 & 2.18 & 1 gate only at 602 & 630 & 588.1 \\
\hline 122 & 1,500 & 1.09 & 1 gate only 595.6 & 630 & 585.8 \\
\hline 123 & 2,000 & 1.45 & 1 gate at 597.8 & 630 & $585.8 / 586.8 / 584.6 / 583.6$ \\
\hline 124 & 2,500 & 1.82 & 1 gate at 600.0 & 630 & 588.5 \\
\hline
\end{tabular}

Tests $103-115$ were performed to determine if any of the rock in the $18 \mathrm{in}$. blanket thickness gradation would move either in the upstream or downstream direction, but no rock movement was observed. For Tests 116 -124, different gate operations were employed to see if any conditions produced enough turbulent flow to pick up riprap from the end of the concrete apron upstream to the stilling basin.

Although very large horizontal eddies formed within the basin, no rock in the exit channel was moved in either the upstream or downstream direction. These tests were performed since NAB indicated that these gates 
are sometimes operated separately for repair and maintenance. Just in a short period of time, it was evident in the model testing that a small amount of change in the gate settings yields quite a large horizontal eddy within the basin. This is not desirable especially when rock and debris are trapped within the basin walls as it would cause an increase in concrete damaged within the stilling basin.

The tests show that the chance of riprap being pulled into the stilling basin is low. A few potential explanations have been developed on why riprap was and is still being found within the stilling basin during diving inspections. One potential explanation is the larger rock has been present since construction and opening of the dam. During the placement of the larger rock within the $36 \mathrm{in}$. blanket thickness zone, it is possible that larger rock rolled down the concrete apron and over time, with certain flow conditions, made its way into the basin. Also, divers have found large rock sitting on the apron but no indication that this rock had been rolling or sliding around. During testing, rock was placed on the apron near the end sill, halfway up the apron, and towards the end of the apron. There were flow conditions that caused the rock to slide around on the apron and a few conditions where rock that was placed near the end sill was pulled into the basin. As discussed in Section 3.1.3, rock that was placed towards the end of the apron never moved upstream.

Another potential explanation is that people who fish near the stilling basin purposely throw rocks up to $12 \mathrm{in}$. in diameter into it. This theory is viable since many people fish in the area of the stilling basin, the area is easily accessible by visitors, and dam operators have seen people perform this action.

One last potential explanation that cannot be ruled out is that smaller rock from the upstream approach channel may move through the gate structure and into the stilling basin. Although tests were performed to replicate that behavior, a more thorough investigation is required to ensure whether this theory is viable. This however does not apply to larger rock 2 to $3 \mathrm{ft}$ in diameter that has been found within the basin. The specifications for the gradation of the riprap in the approach channel does not show this size rock.

Note that there is no observable loss of riprap protection on the riprap slope on each bank downstream of the stilling basin (USACE NAB 2015). 
Also, divers commented the riprap apron just downstream of the concrete apron appears uniform with no major holes or missing stones (USACE $\mathrm{NAB}$ 2015). Further, the divers report that the concrete and riprap apron interface is in satisfactory condition (USACE NAB 2015). Therefore, it is unclear on where the riprap in the stilling basin is coming from. If the amount of riprap needed to cause the observed damage is large enough, an area where the riprap is being entrained and moved into the stilling basin should be visible.

\subsection{Stilling basin modifications}

After determining where the riprap being pulled into the stilling basin is originating from, attention turned to possible stilling basin modifications that would flush riprap that did become trapped within the stilling basin.

\subsubsection{High-sloping fillet added to basin}

A 45-degree fillet made of acrylic was added to the front of the end sill shown in Figure 24 to determine if rock could be flushed from the stilling basin with a lower flow $(<2,000 \mathrm{cfs})$. Rocks ranging from three-eighths in. to 1.0 in. in diameter were added in the bottom of the stilling basin. A few small rocks were flushed out of the basin with a discharge of 3,000 cfs. After the small rocks were replaced in the basin, the small rocks would again be flushed out. However, larger rock would remain in the stilling basin with a 3,000 cfs flow. 
Figure 24. High-slope 45-degree fillet added at the end sill in the stilling basin.

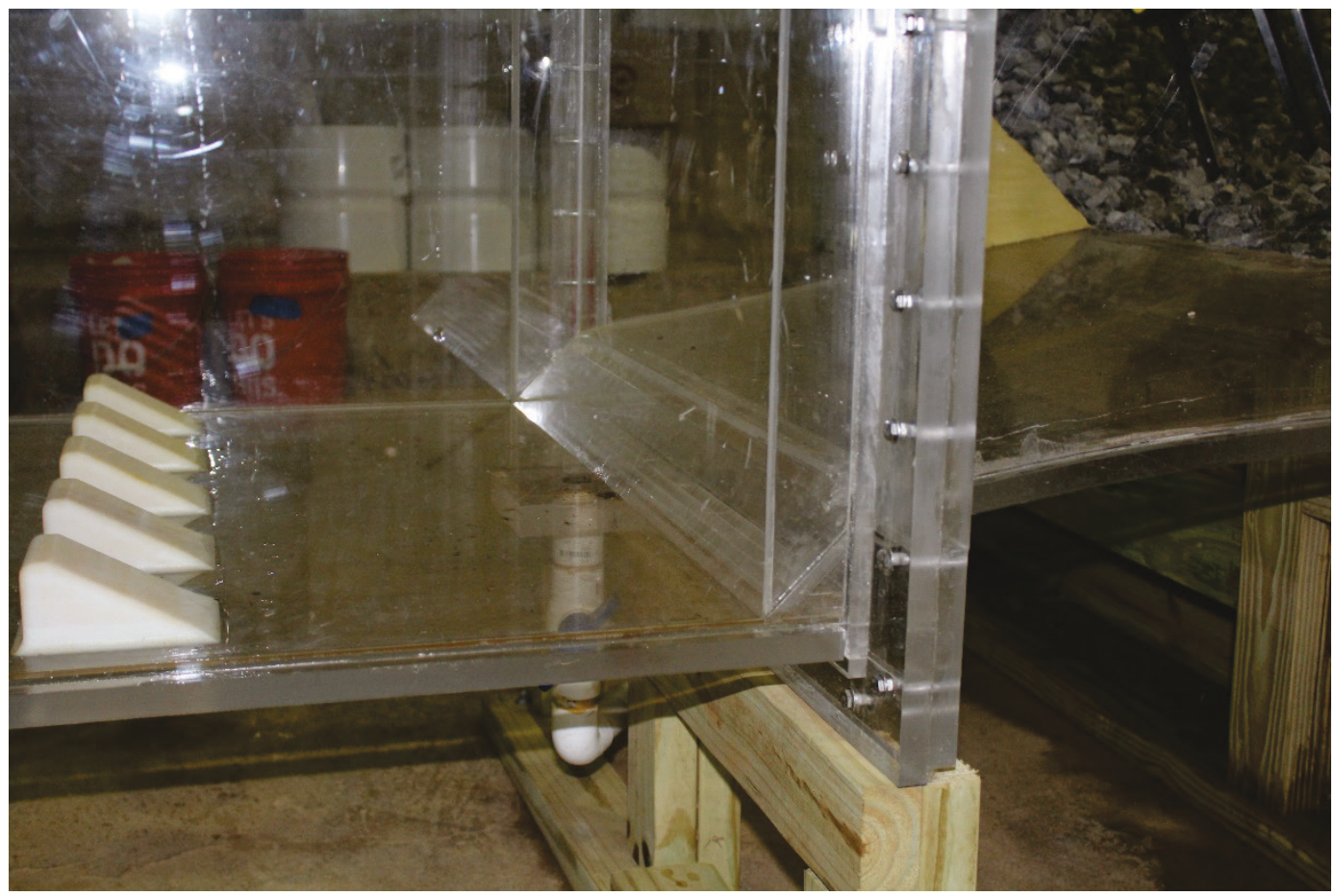

\subsubsection{Low-sloping fillet added to basin}

Another fillet design with a slope similar to the slope of the apron was installed in front of the end sill in the stilling basin and can be seen in Figure 25 to Figure 28. This particular design was approached since the 45-degree fillet previously tested did help to flush out small rock, but the larger rock did not flush out at a flow that was acceptable for the project to do on a periodic basis. The upstream toe of this fillet began at the downstream edge of the baffle blocks and terminated at the top of the end sill.

Figure 25. 3D CAD drawing of fillet added in stilling basin.

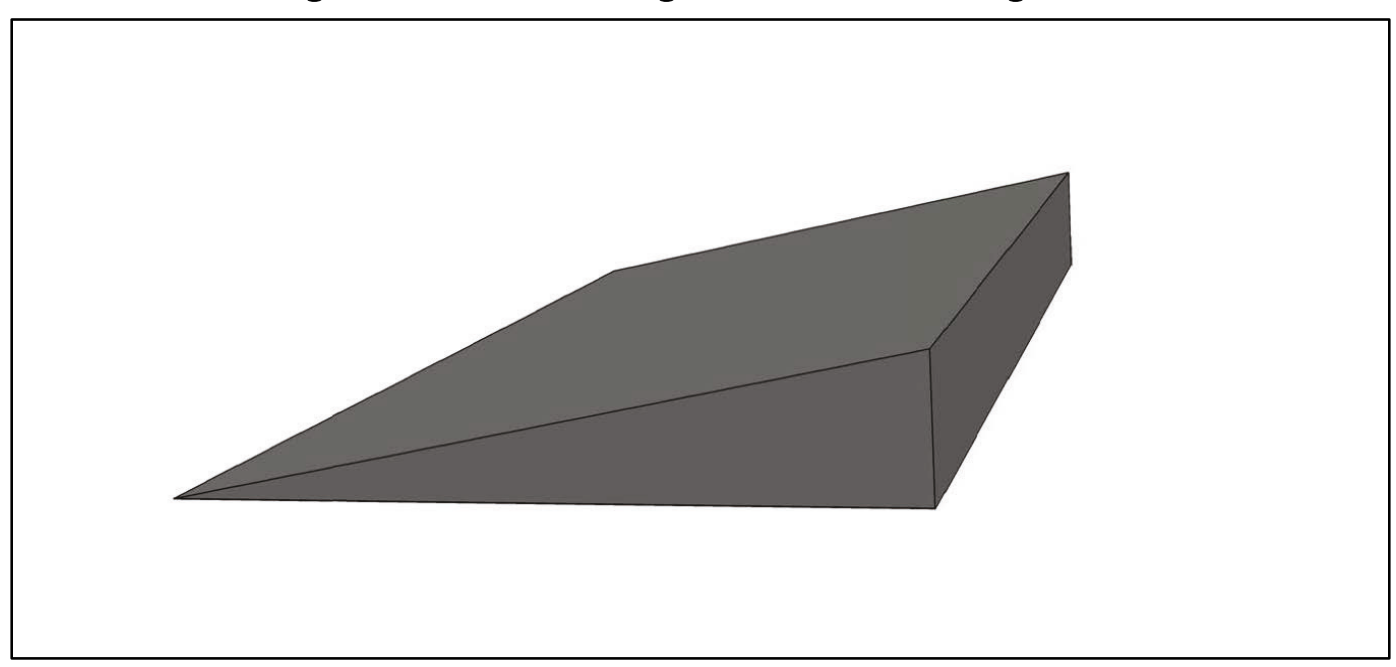


Figure 26. Fillet added in stilling basin; dimensions are in model inches.

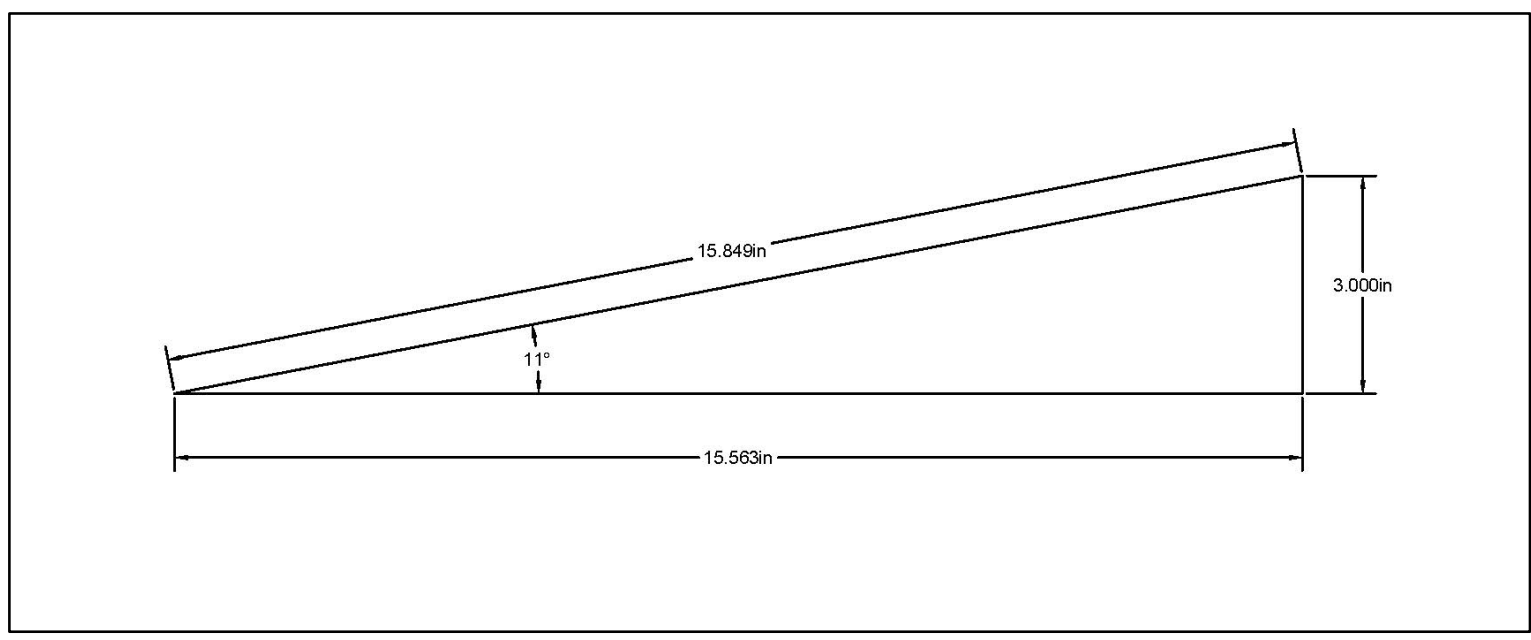

Figure 27. Fillet added in stilling basin, wet.

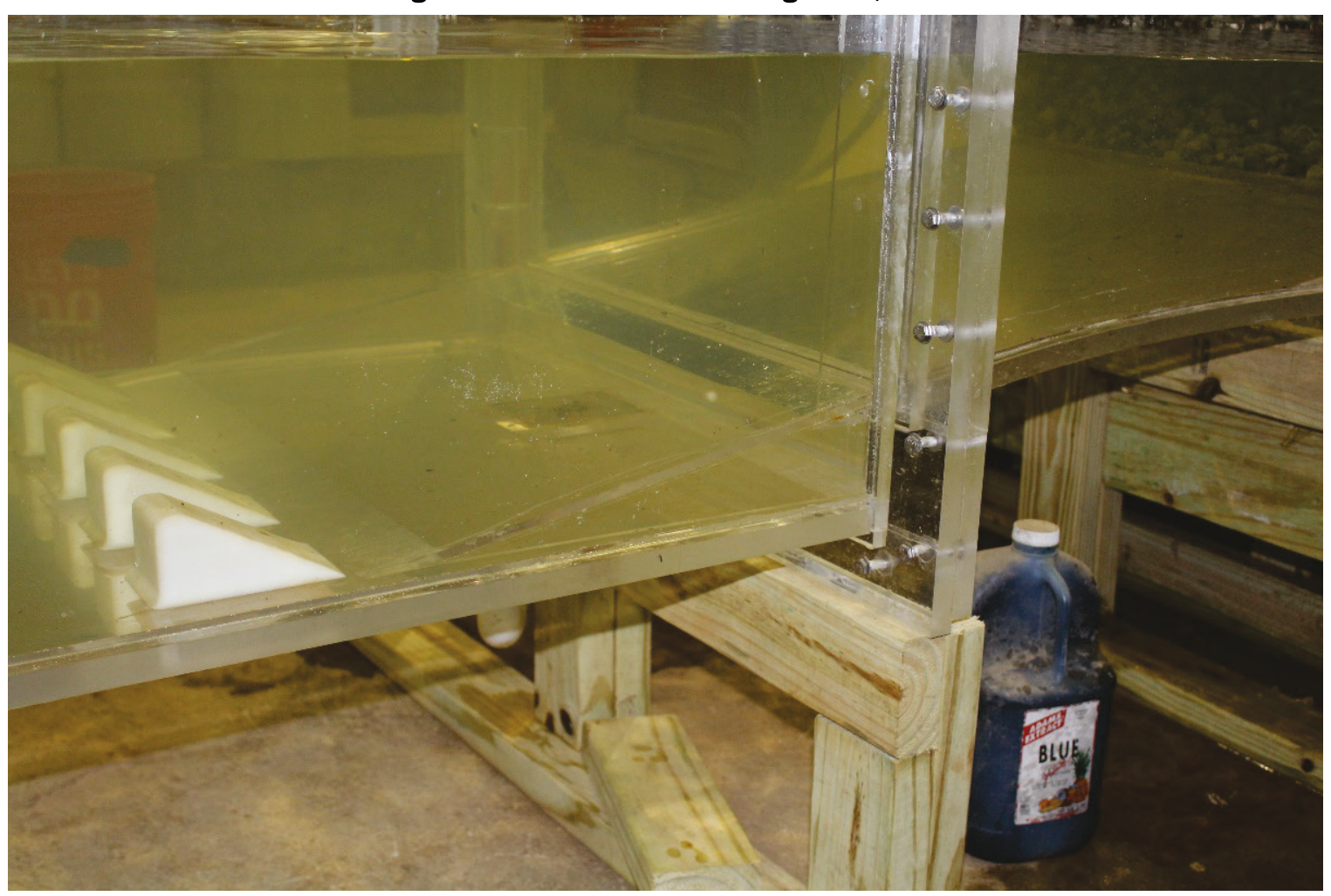


Figure 28. Fillet added in stilling basin, dry.

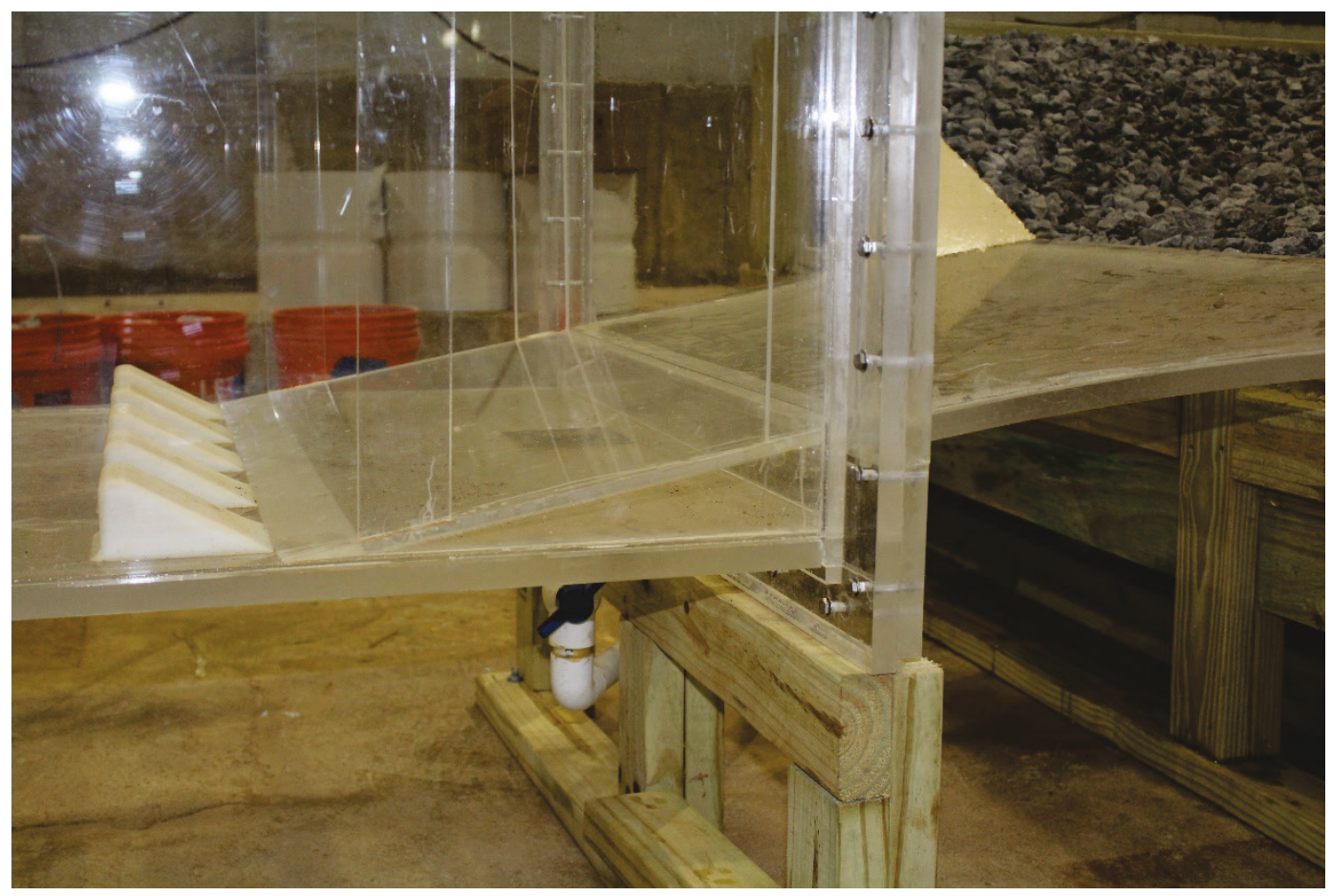

Table 7 lists the tests completed using a movable bed exit channel with the low-slope fillet installed.

This particular fillet insert flushes rock out of the stilling basin at lower flows well. The rocks placed in the basin were three-eighths in. to 1.0 in. diameter, which were equivalent to 6.75 in. to 18 in. stone at the project. For Test 127, with a 1,500 cfs flow, rock moved downstream onto the concrete apron, indicating with a flow of $1,500 \mathrm{cfs}$, rocks would be able to flush out of the basin. Therefore, a sizable rock would be flushed with a flow as low as 1,500 cfs. With a flow of 2,000 cfs in Test 128, all of the rocks placed in the basin were flushed out of the basin and downstream to the end of the concrete apron. Test 130 with a flow of 3,000 cfs flushed all rocks out of the basin. Also during Test 130, very large rock of 2 in. in diameter placed in the stilling basin was flushed to the concrete apron area, and it slowly moved up the apron toward the riprap exit channel. For reference, 2 in. rock in the model would equate to $36 \mathrm{in}$. rock at the project.

Another observation made during the test with the low-slope fillet installed was the turbulence with low flows in the stilling basin was noticeably less than without the fillet piece. This concludes that with the low-slope fillet in, if rock were placed or pulled into the basin, it would not swirl around on the bottom of the basin causing concrete degradation at a 
low flow. Since the project annually releases at least a $2000 \mathrm{cfs}$ flow, the low-slope fillet insert would flush any rocks out of the basin.

To ensure the low-slope fillet insert does not adversely affect the stilling basin or exit channel for larger flows, discharges up to the design flow of the project were observed. Even with the 18 in. riprap blanket thickness rock installed in the $36 \mathrm{in}$. riprap area, the riprap did not move upstream or downstream during these tests. Since the 18 in. riprap blanket thickness in place during these tests was a conservative gradation representing the $36 \mathrm{in}$. zone, the low-slope fillet insert will not cause adverse effects downstream.

Table 7. Movable bed tests with low-slope fillet piece.

\begin{tabular}{|c|c|c|c|c|c|}
\hline Test & $\begin{array}{l}\text { Prototype } \\
\text { (cfs) }\end{array}$ & $\begin{array}{l}\text { Model } \\
\text { (cfs) }\end{array}$ & $\begin{array}{l}\text { Gate Opening } \\
\text { Elevation }(\mathrm{ft})\end{array}$ & $\begin{array}{l}\text { Headwater Elevation } \\
\text { (ft) }\end{array}$ & $\begin{array}{l}\text { Tailwater Elevation } \\
\text { (ft) }\end{array}$ \\
\hline 125 & 615 & 0.45 & 591.25 & 630 & 583.6 \\
\hline 126 & 1,000 & 0.73 & 591.8 & 630 & 584.7 \\
\hline 127 & 1,500 & 1.09 & 592.8 & 630 & 585.8 \\
\hline 128 & 2,000 & 1.45 & 593.9 & 630 & 586.8 \\
\hline 129 & 2,500 & 1.82 & 595 & 630 & 587.5 \\
\hline 130 & 3,000 & 2.18 & 596 & 630 & 588.1 \\
\hline 131 & 3,000 & 2.18 & 596 & 630 & 586.8 \\
\hline 132 & 3,500 & 2.55 & 597 & 630 & 588.6 \\
\hline 133 & 3,500 & 2.55 & 597 & 630 & 587.3 \\
\hline 134 & 1,000 & 0.73 & 591.8 & 630 & 584.7 \\
\hline 135 & 1,500 & 1.09 & 592.8 & 630 & 585.8 \\
\hline 136 & 2,000 & 1.45 & 593.9 & 630 & 586.8 \\
\hline 137 & 2,500 & 1.82 & 595 & 630 & 587.5 \\
\hline 138 & 4,000 & 2.81 & 598.1 & 630 & 589.1 \\
\hline 139 & 4,000 & 2.81 & 598.1 & 630 & 587.7 \\
\hline 140 & 4,500 & 3.27 & 599.2 & 630 & 589.5 \\
\hline 141 & 4,500 & 3.27 & 599.2 & 630 & 588.2 \\
\hline 142 & 5,000 & 3.64 & 600.1 & 630 & 589.9 \\
\hline 143 & 6,000 & 4.36 & 602.1 & 630 & 590.6 \\
\hline 144 & 7,000 & 5.09 & 605 & 632 & 591.3 \\
\hline 145 & 8,000 & 5.82 & 605 & 641 & 591.9 \\
\hline 146 & 9,300 & 6.76 & 605 & 657 & 592.7 \\
\hline
\end{tabular}




\subsubsection{Inverted $V$ added to parabolic drop}

An inverted $\mathrm{V}$ insert was added to the parabolic trajectory to determine its effect on low-flow eddies in the stilling basin. The inverted $V$ was designed based on guidance (HQUSACE 1980) (WES 1977). Table 8 lists all tests completed with the inverted V insert installed. Tests $147-159$ were conducted with the inverted $\mathrm{V}$ insert and no fillet inserts, and Tests $160-169$ were conducted with the inverted $\mathrm{V}$ insert installed and the low-slope fillet insert.

Table 8. Movable bed tests with inverted V insert.

\begin{tabular}{|l|l|l|l|l|l|}
\hline Test & $\begin{array}{l}\text { Prototype } \\
\text { (cfs) }\end{array}$ & $\begin{array}{l}\text { Model } \\
\text { (cfs) }\end{array}$ & $\begin{array}{l}\text { Gate Opening Elevation } \\
\text { (ft) }\end{array}$ & $\begin{array}{l}\text { Headwater Elevation } \\
\text { (ft) }\end{array}$ & $\begin{array}{l}\text { Tailwater Elevation } \\
\text { (ft) }\end{array}$ \\
\hline 147 & 1,500 & 1.09 & 592.8 & 630 & 585.8 \\
\hline 148 & 1,000 & 0.73 & 591.8 & 630 & 584.7 \\
\hline 149 & 615 & 0.45 & 591.25 & 630 & 583.6 \\
\hline 150 & 150 & 0.11 & 590.3 & 630 & 581.8 \\
\hline 151 & 2,000 & 1.45 & 593.9 & 630 & 586.8 \\
\hline 152 & 2,500 & 1.82 & 595 & 630 & 587.5 \\
\hline 153 & 3,000 & 2.18 & 596 & 630 & 588.1 \\
\hline 154 & 3,500 & 2.55 & 597 & 630 & 588.6 \\
\hline 155 & 4,000 & 2.81 & 598.1 & 630 & 589.1 \\
\hline 156 & 5,000 & 3.64 & 600.1 & 630 & 589.9 \\
\hline 157 & 6,000 & 4.36 & 602.1 & 630 & 590.6 \\
\hline 158 & 8,000 & 5.82 & 605 & 641 & 591.3 \\
\hline 159 & 9,300 & 6.76 & 605 & 657 & 592.7 \\
\hline 160 & 615 & 0.45 & 591.25 & 630 & 583.6 \\
\hline 161 & 1,000 & 0.73 & 591.8 & 630 & 584.7 \\
\hline 162 & 1,500 & 1.09 & 592.8 & 630 & 585.8 \\
\hline 163 & 2,000 & 1.45 & 593.9 & 630 & 586.8 \\
\hline 164 & 2,500 & 1.82 & 595 & 630 & 587.5 \\
\hline 165 & 3,000 & 2.18 & 596 & 630.1 \\
\hline 166 & 3,500 & 2.55 & 597 & 580.6 \\
\hline 167 & 4,000 & 2.81 & 598.1 & 589.1 \\
\hline 168 & 4,500 & 3.27 & 599.2 & 605 & 591.3 \\
\hline 169 & 7,000 & 5.09 & 630.5 & \\
\hline & & & & 630 & 5 \\
\hline
\end{tabular}


A condition described in Section 3.1.2, the flow in previous tests indicated the flow exiting the culvert would oscillate from one side of the stilling basin to the other, which causes large horizontal eddies with flows at or below 2,000 cfs. The inverted $\mathrm{V}$ is designed to divide the flow exiting the culvert evenly and direct it down both sides of the stilling basin. The intent is to prevent horizontal eddies from forming and ensure the flow is uniform within the stilling basin. Dry bed views of the inverted $V$ installed in the basin are shown in Figure 29 to Figure 32.

Figure 29. CAD drawings of the inverted $\mathrm{V}$ added to the parabolic trajectory.

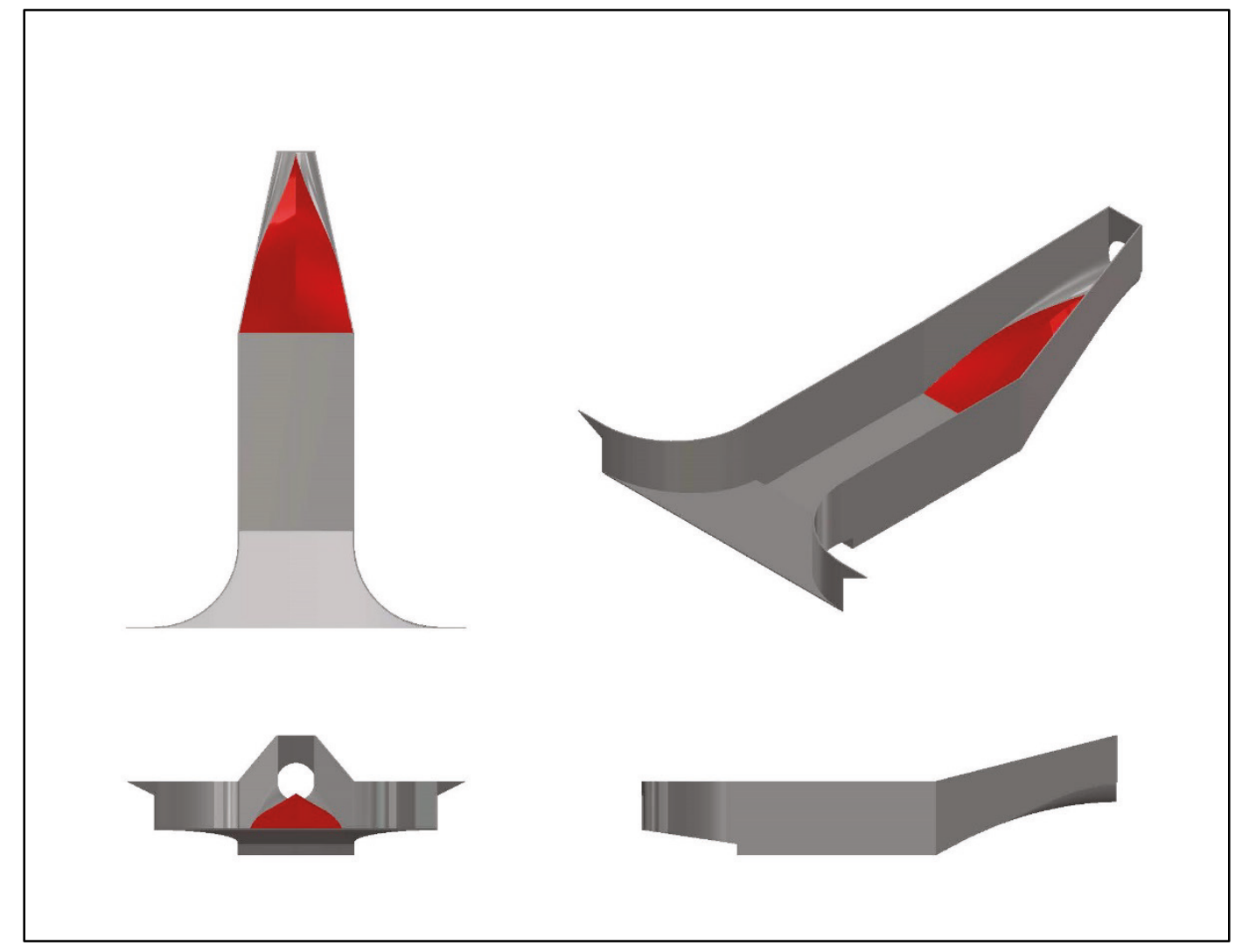


Figure 30. View of inverted V added to parabolic trajectory.

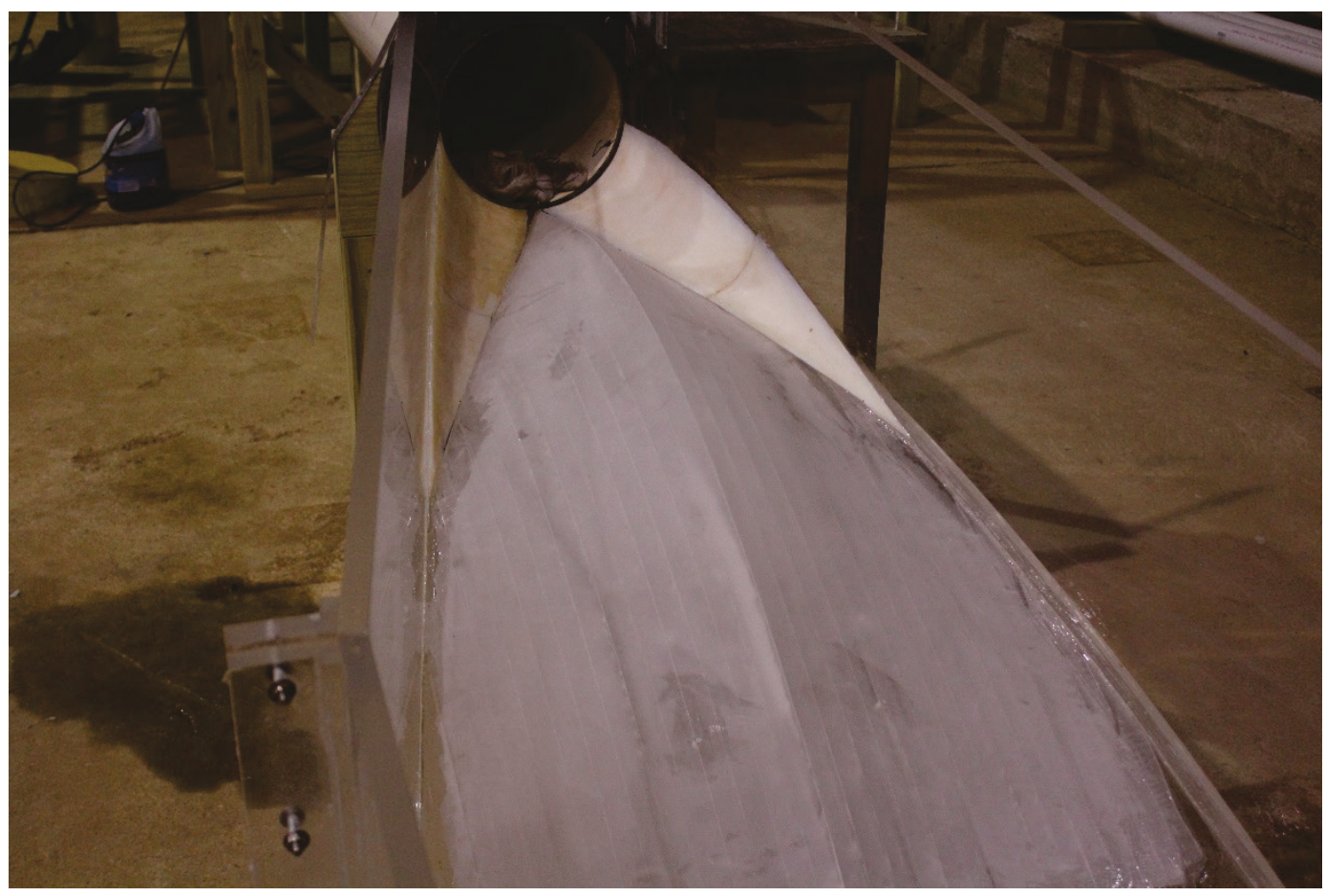

Figure 31. View looking upstream of inverted $\mathrm{V}$ added to parabolic trajectory.

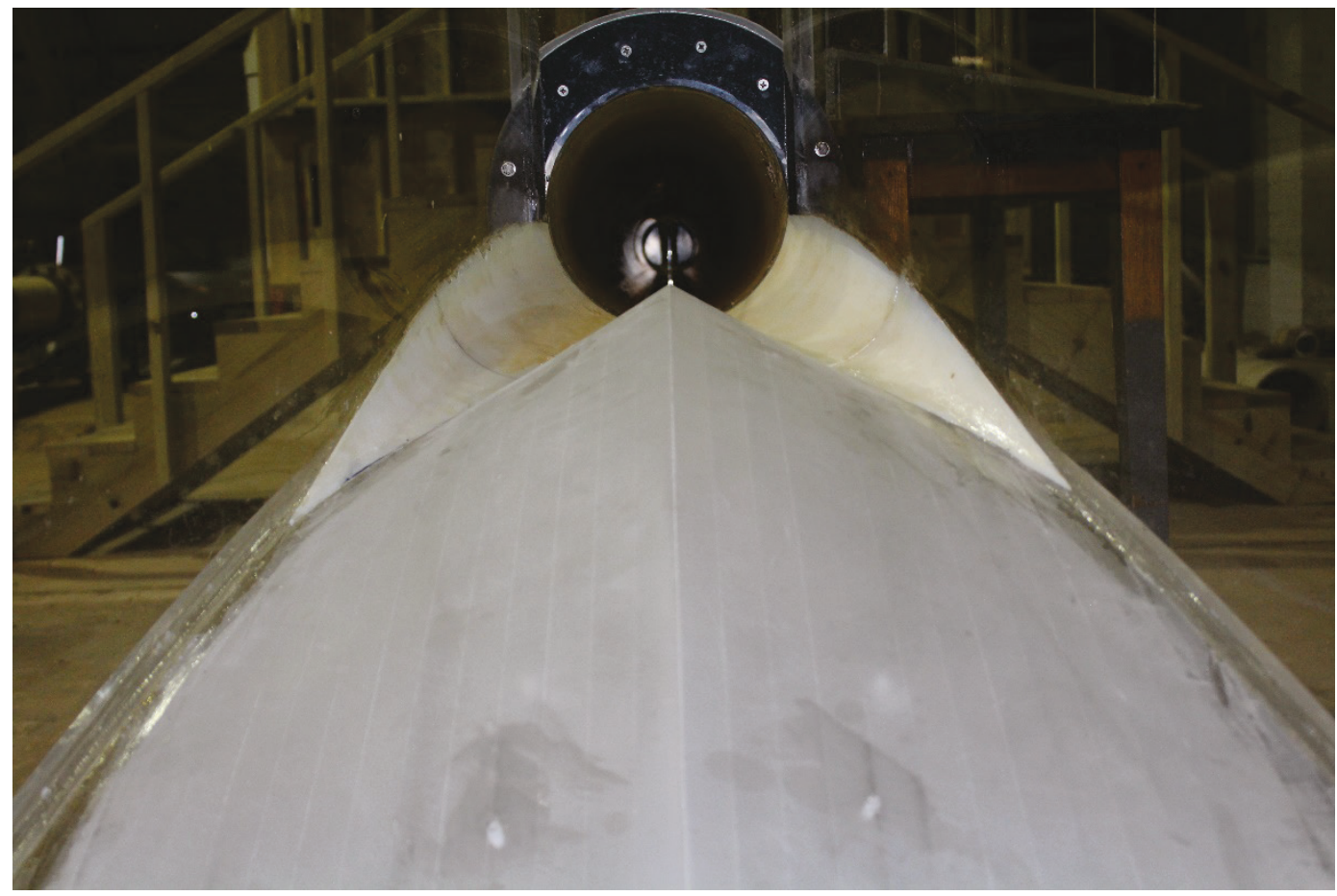


Figure 32. Side view of inverted V added to parabolic trajectory.

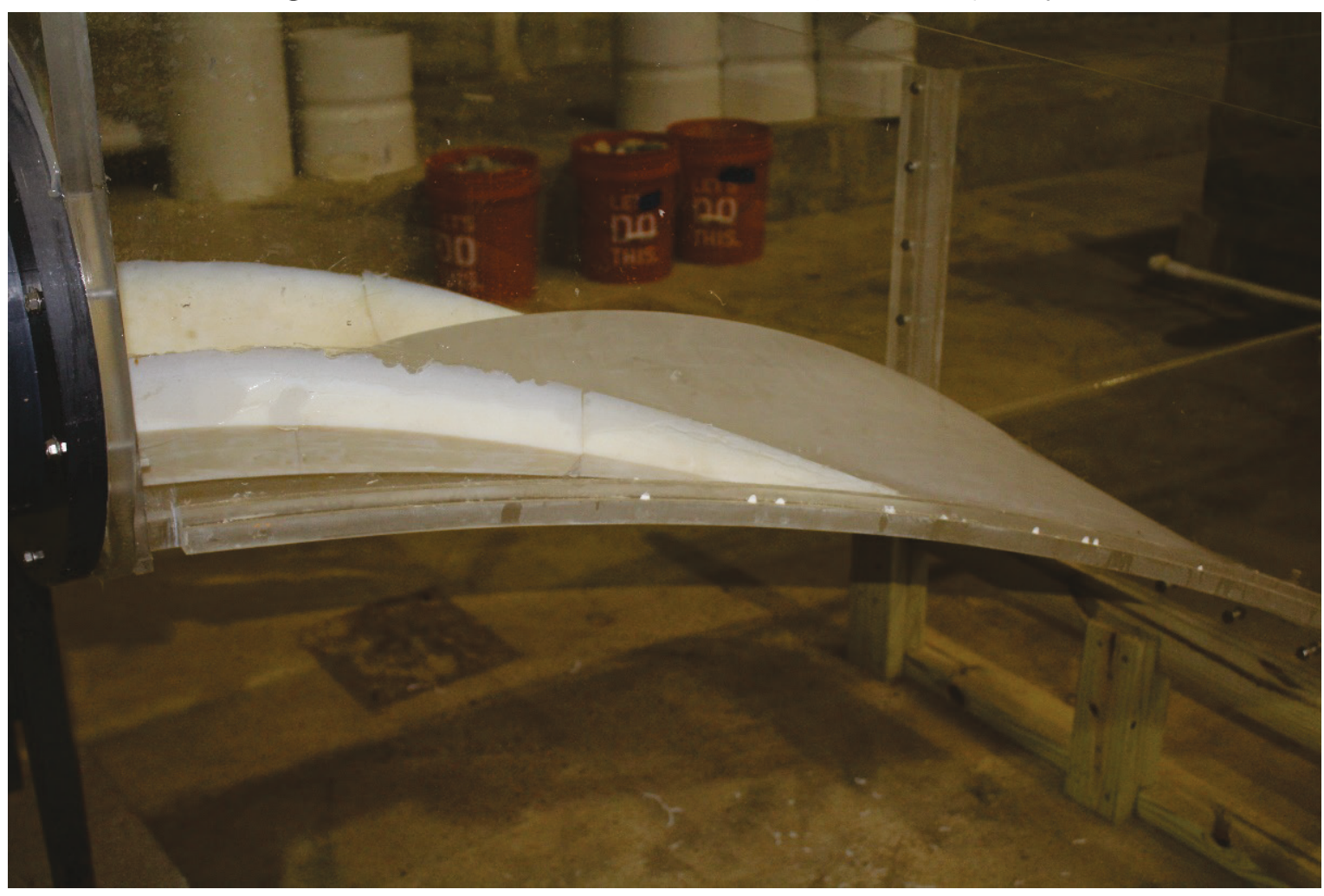

The inverted $\mathrm{V}$ divided the flow equally to each side of the stilling basin for flows at or below 2,000 cfs. Also, rocks that were placed in the basin did not move around as much indicating less turbulence in the bottom of the basin for flows up to $1,500 \mathrm{cfs}$. In previous low-flow tests without the inverted $\mathrm{V}$ insert, rocks were observed to swirl around on the bottom of the basin much more. This would be ideal for the Sayers project since a large majority of the flows experienced at the project annually are in the 150 to 500 cfs range. Figure 33 and Figure 34 show the inverted V with a 1,000 cfs flow. 
Figure 33. View looking upstream with a discharge of 1,000 cfs and the inverted V installed.

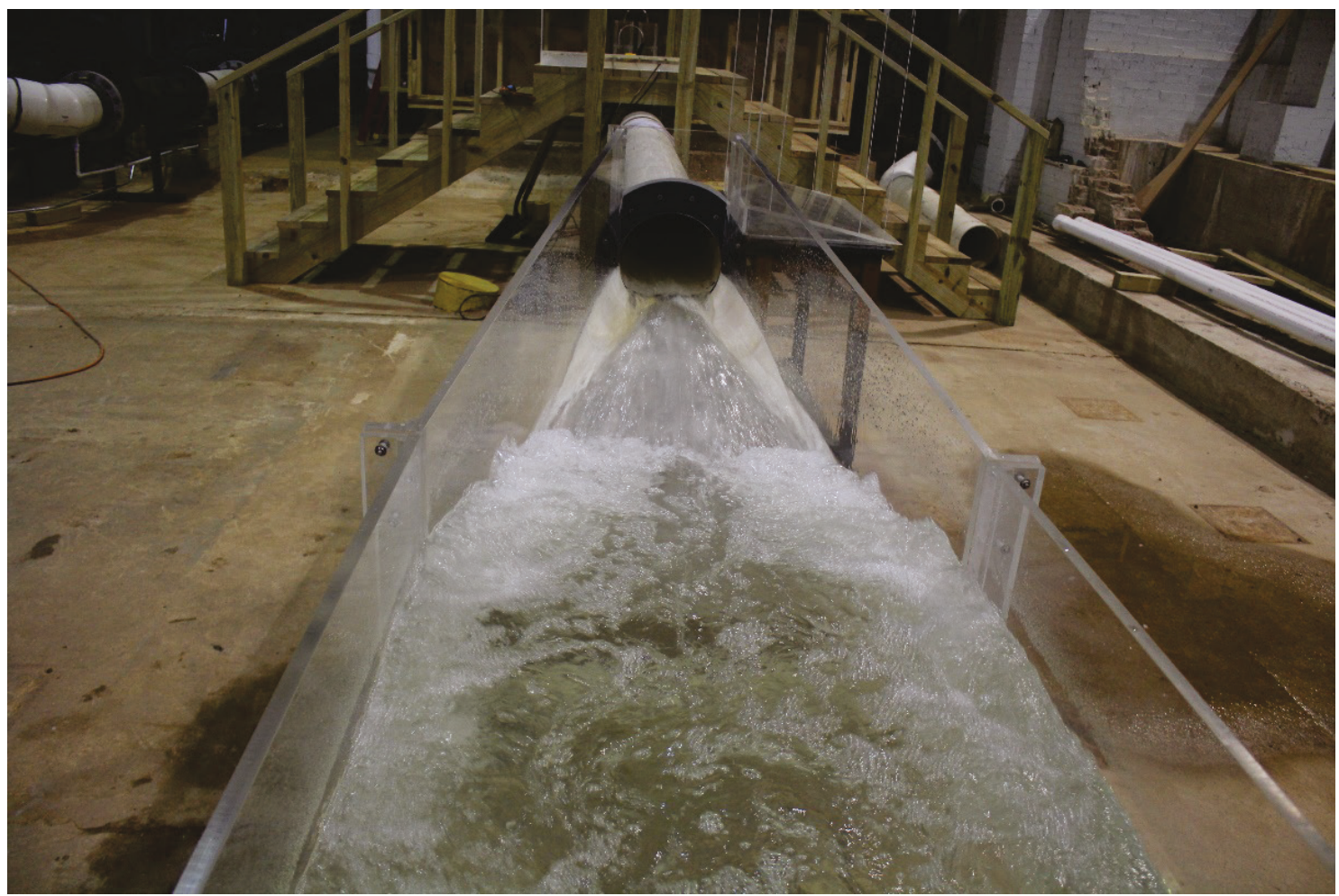

Figure 34. View looking downstream with a discharge of 1,000 cfs and the inverted V installed.

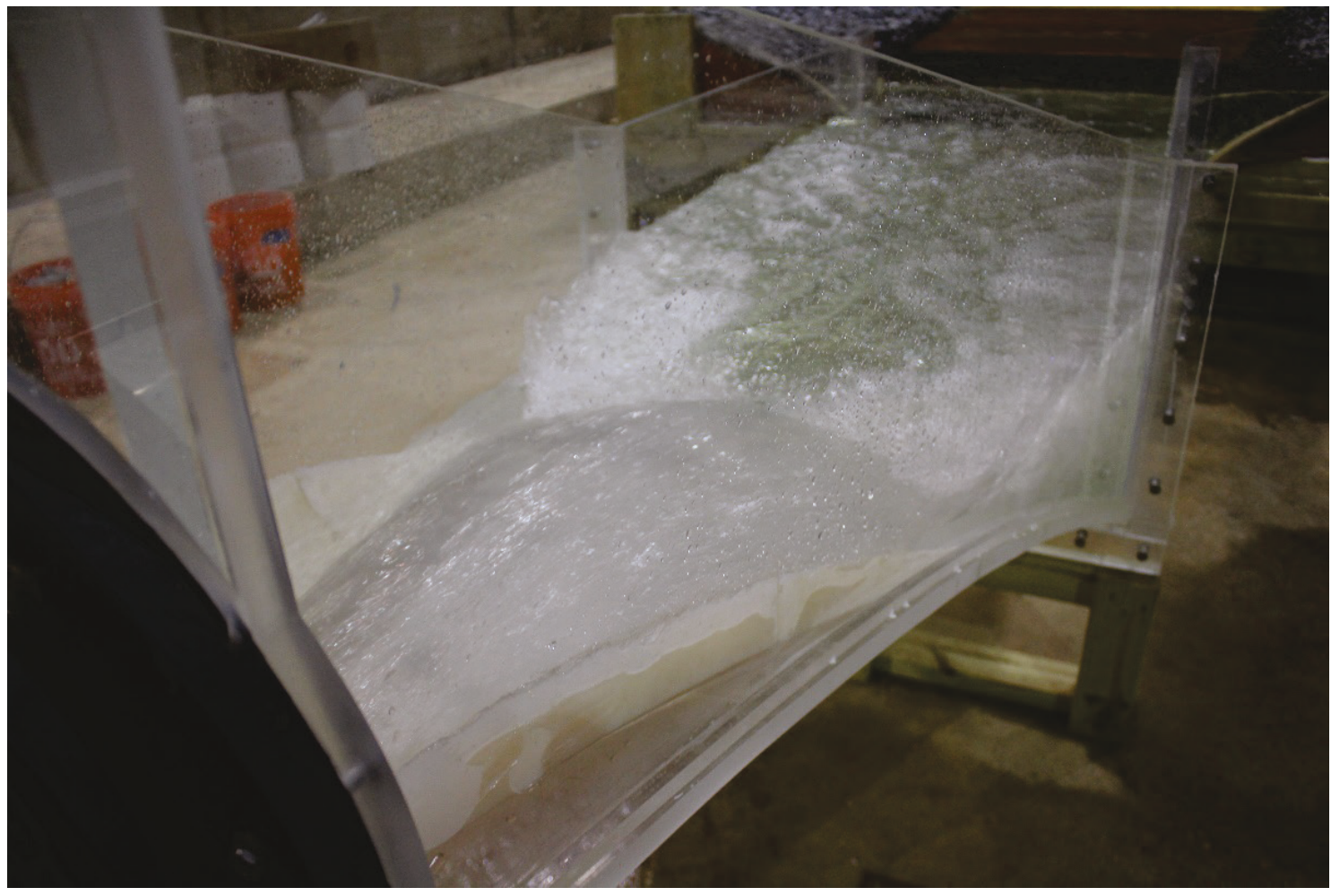


During the tests, the flow inside the stilling basin became more turbulent as the discharge increased compared to previous tests without the inverted $\mathrm{V}$ insert installed. With the inverted $\mathrm{V}$ dividing the flow to each side of the stilling basin, the effect of a higher current was evident on each side above the concrete and riprap apron. It was also observed that once the tests were completed, some riprap in the exit channel was displaced and moved downstream. Movement was observed on the channel invert as well as the side slopes of the exit channel.

Tests were conducted up to the design discharge of the project, 9,300 cfs without the fillet installed. The very small rock, three-eighths in. diameter, that was placed in the stilling basin started to flush out at 4,000 cfs with most out of the basin by 6,000 cfs. For comparison, rocks placed in the stilling basin with no inserts did not begin to flush out of the basin until 6,000 cfs.

Tests $160-169$ were conducted with the inverted V insert and the low-slope fillet insert installed. The lower flows $(<2,000 \mathrm{cfs})$ were divided as expected in the stilling basin with a more uniform flow result. The flow in the stilling basin was less turbulent as indicated in previous tests with the inverted $\mathrm{V}$ insert for flows up to 1,500 cfs. In previous tests with only the low-slope fillet insert installed, rocks were flushed from the basin as early as $1,000 \mathrm{cfs}$ with all out by $1,500 \mathrm{cfs}$. The tests with the inverted $\mathrm{V}$ and low-slope fillet inserts indicated that onset of flushing is near $1,500 \mathrm{cfs}$. The small rocks were flushed first, but the larger rocks (18 in. diameter prototype) did not begin flushing out until 4,000 cfs. A very large rock (36 in. diameter prototype) moved to the center of the fillet insert in the center of the basin and was not moved. The inverted $V$ causes a very low flow area in the center of the stilling basin, and most rocks that were entrapped in this area either were not flushed at all or were not flushed as early as they would have without the inverted V insert installed.

Test 169 was the final test performed with the inverted $\mathrm{V}$ and low-slope fillet inserts installed. Rocks began to flush downstream from the 36 in. blanket zone. No further tests were conducted with higher flows because of the risk of the exit channel being further damaged. Higher turbulence flows were seen with the inverted $\mathrm{V}$ installed.

To design and construct an inverted $\mathrm{V}$ at the project would be challenging and expensive. Currently, the existing parabolic drop has a foundation 
which is only $3 \mathrm{ft}$ thick of concrete. To ensure an adequate foundation for the inverted $\mathrm{V}$ on the parabolic drop, design considerations would be needed to ensure the structural stability of the inverted $V$ was adequate in the project.

\subsubsection{Baffle blocks removed in stilling basin}

The last tests (Tests $170-176)$ were conducted with the baffle blocks removed from the stilling basin. The existing baffle blocks are badly damaged; therefore, NAB wanted to explore the possibility of removing the baffle blocks altogether. Figure 35 shows the stilling basin with the baffle blocks removed. The test conditions are summarized in Table 9.

Figure 35. Flow conditions in the stilling basin with a discharge of 5,000 cfs and the baffle blocks removed.

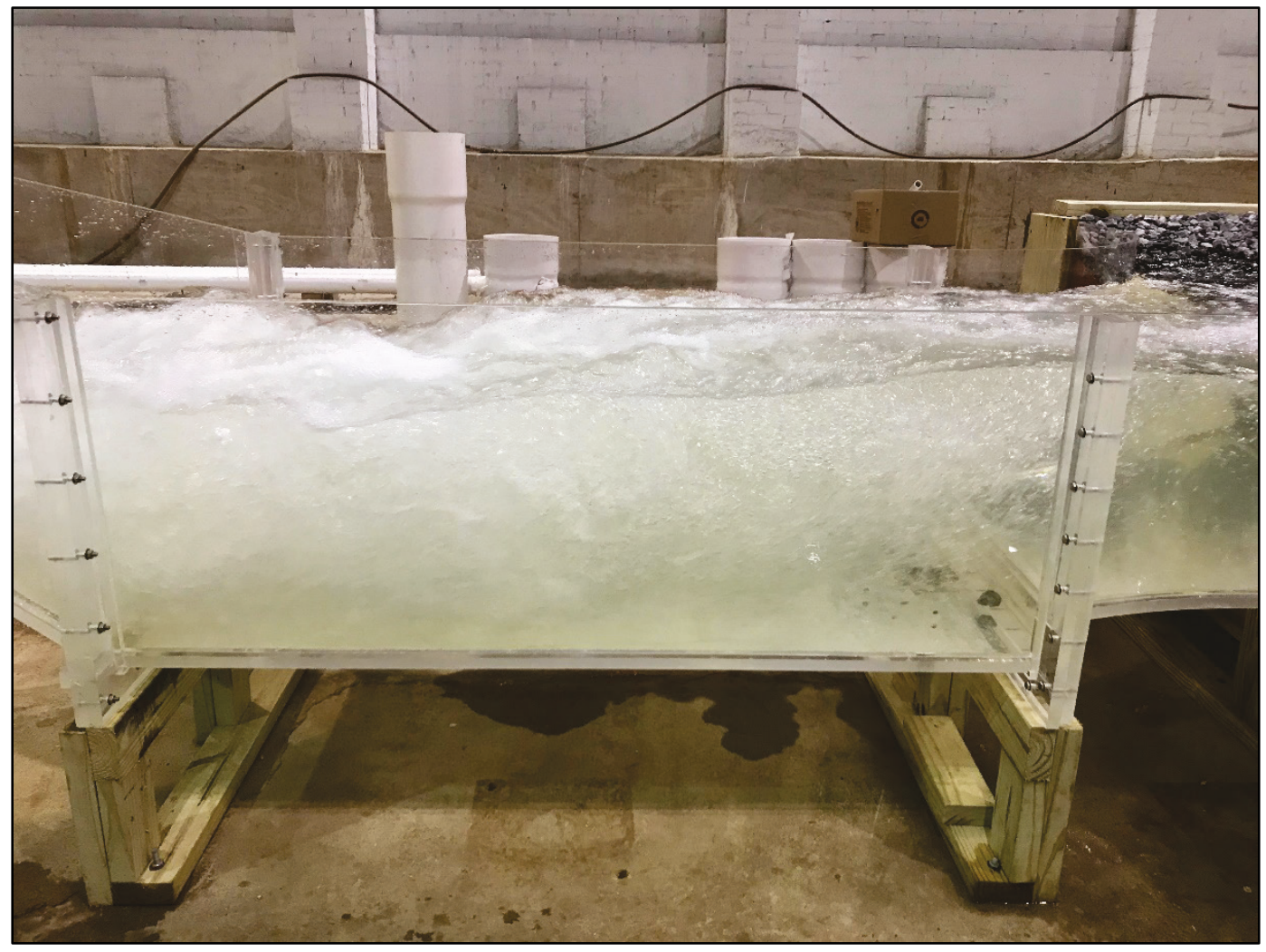


Table 9. Movable bed tests with no baffle blocks.

\begin{tabular}{|l|l|l|l|l|l|}
\hline Test & $\begin{array}{l}\text { Prototype } \\
\text { (cfs) }\end{array}$ & $\begin{array}{l}\text { Model } \\
(\mathrm{cfs})\end{array}$ & $\begin{array}{l}\text { Gate Opening } \\
\text { Elevation }(\mathrm{ft})\end{array}$ & $\begin{array}{l}\text { Headwater Elevation } \\
(\mathrm{ft})\end{array}$ & $\begin{array}{l}\text { Tailwater Elevation } \\
(\mathrm{ft})\end{array}$ \\
\hline 170 & 615 & 0.45 & 591.25 & 630 & 583.6 \\
\hline 171 & 1,000 & 0.73 & 591.8 & 630 & 584.7 \\
\hline 172 & 1,500 & 1.09 & 592.8 & 630 & 585.8 \\
\hline 173 & 2,000 & 1.45 & 593.9 & 630 & 586.8 \\
\hline 174 & 3,000 & 2.18 & 596 & 630 & 588.1 \\
\hline 175 & 4,000 & 2.81 & 598.1 & 630 & 589.1 \\
\hline 176 & 5,000 & 3.64 & 600.1 & 630 & 589.9 \\
\hline
\end{tabular}

For Tests 170 and 171, with $615 \mathrm{cfs}$ and 1,000 cfs, respectively, the flow conditions in the stilling basin were similar to the tests with the baffle blocks present. However, for Test 172, with a 1,500 cfs flow, rocks that were placed within the stilling basin were violently moved around on the bottom of the stilling basin. Also, the horizontal eddy formed on the left side was noticeably larger than the horizontal eddy observed with baffle blocks present. This larger horizontal eddy attributed to the rocks moving violently around on the bottom of the stilling basin. Since Sayers Dam releases 1,500 cfs flow annually, removal of the blocks would be detrimental to the project.

Small rocks within the stilling basin began flushing at 2,000 cfs. These rocks had a diameter of one-fourth to one-half in., equivalent to a 4.5 in. to 9 in. rock at the project. As the flow increases, an adequate hydraulic jump still formed in the basin. For Test 175, at 4,000 cfs, more rock continued to flush with the larger rock starting to flush also. By Test 176, all of the smaller diameter rocks were flushed with a few larger diameter rock still present in the stilling basin. With the higher flows, more flow energy was leaving the stilling basin, and the water surface in the exit channel was much rougher. The baffle blocks are needed to form a strong hydraulic jump and provide adequate energy dissipation. 


\section{Summary and Recommendations}

\subsection{Summary of physical model study}

A physical model study of Foster Joseph Sayers Dam Outlet Works was conducted to evaluate the hydraulic performance of the stilling basin and exit channel and to develop proposed modifications to the stilling basin and exit channel to provide satisfactory performance. Altogether, 176 tests were conducted for the physical model study. Existing flow conditions and potential modifications to the stilling basin to improve flow characteristics for the basin were tested and evaluated.

Tests with a fixed bed exit channel were conducted initially to document flow conditions in the stilling basin and exit channel. Results of the model tests and results of the field discharge tests performed by NAB were compared to ensure that the model reproduced the flow conditions of the field tests very well.

During testing of low flows ( $<2,000 \mathrm{cfs}$ ), the flow in the stilling basin would oscillate from side to side, causing very large horizontal eddies forming on one side of the stilling basin. The large eddy would cause asymmetrical flow at the floor of the stilling basin, which violently moved rock that had been placed on the floor of the stilling basin. Rock placed in the stilling basin during testing did not begin to flush until 6,000 cfs. These results indicate it is not feasible for the project to periodically flush riprap out of the original design basin because the project normally only releases 2,500 cfs or less annually.

Tests to evaluate flow conditions in the stilling basin with the fixed bed exit channel were also conducted for the winter and summer pool elevations. Rock was placed on the lower concrete apron to evaluate the potential of a back roller event that would cause riprap to move upstream to the stilling basin. With the two gates in the gate structure operated symmetrically, no rock was viewed being drawn back upstream into the basin. If the gates in the gate structure were set at different openings, a large horizontal eddy formed within the basin. This eddy can move large rock from the concrete apron upstream to the stilling basin. However, rock that was placed toward the downstream end of the concrete apron as well as on the riprap apron only moved downstream. These fixed-bed tests conducted up to the design 
discharge did not show any conditions where rock would move upstream from the riprap apron area into the stilling basin.

The upstream rock protection was simulated using a 12 in. thick riprap blanket thickness placed on the upstream approach channel floor. These tests were conducted to determine if the riprap could be pulled through the gate structure and end up in the stilling basin. None of the tests conducted showed any signs that riprap could possibly move through the gate structure into the stilling basin.

Tests were then completed with a movable bed exit channel installed. Two sizes of riprap blanket thicknesses were installed, a $36 \mathrm{in}$. blanket thickness zone immediately downstream of the stilling basin and an 18 in. blanket thickness zone that was placed just on the sides of the exit channel downstream of the $36 \mathrm{in}$. zone. The riprap design matched the as built drawings. The $36 \mathrm{in}$. blanket thickness riprap gradation was not provided by NAB; therefore, a 36 in. blanket thickness gradation was developed based on guidance used for the other gradations provided by NAB. The rock size using this approach resulted in much bigger riprap than that observed at the project. Tests performed with the bigger rock installed yielded no rocks being pulled from the exit channel back into the stilling basin. A different approach using guidance (HQUSACE 1980) was used to develop another gradation. This approach used the average velocity over the end sill computed for the design discharge to size the riprap. This approach indicated that a 21 to 24 in. riprap blanket thickness could be used. The $18 \mathrm{in}$. gradation provided by NAB was then placed in the area where the $36 \mathrm{in}$. blanket thickness had previously been located. This approach was considered to be a conservative approach.

The 18 in. gradation riprap was installed in the 36 in. riprap zone but was doubled to provide the 36 in. riprap blanket thickness required by drawings. All tests completed with the 18 in. thick riprap installed in the 36 in. thick zone resulted with no riprap movement upstream, indicating riprap being pulled into the stilling basin by a back roller event is extremely unlikely.

Proposed explanations of possible ways riprap was being pulled into the stilling basin, becoming entrapped and causing damage to the stilling basin, were discussed. These explanations are as follows: 
- Larger rock has been present since construction.

- Visitors of the project are throwing riprap into the stilling basin.

- Smaller rock is being entrained from the upstream approach channel.

The most viable theory was visitors throwing riprap into the basin. During a site visit to the U.S. Army Engineer Research and Development Center (ERDC) by NAB, a Sayers dam operator explained that many people have been observed throwing riprap into the stilling basin. This explanation, however, does not account for the large riprap seen by divers. There is no indication from the diving reports that the large riprap was recently pulled into the basin, only that it is present.

Although tested, but not thoroughly, an occasional piece of riprap could still be coming from the upstream approach channel. Further testing would be necessary to fully discount this possibility and potential. This again does not explain, however, where the larger 2 to $3 \mathrm{ft}$ diameter rock is entrained since the gradation of the approach channel riprap would not be indicative of this size. With any of the explanations, there is no observable loss of riprap protection on the riprap slope on each bank downstream of the stilling basin. Divers commented the riprap apron just downstream of the concrete apron appears to be uniform with no major holes or missing stones (USACE NAB 2015).

Divers commented that the concrete and riprap apron interface is in satisfactory condition as well. Therefore, the original location of the riprap is unknown at the project. If the amount of riprap needed to cause the observed damage to the stilling basin is large enough, an area where the riprap is originating should be visible.

Attention was then focused on testing different stilling basin geometry modifications to provide better flow characteristics within the stilling basin to help flush riprap that became entrapped. Design changes to the stilling basin tested were the following:

- high slope fillet insert in front of end sill

- low slope fillet insert in front of end sill

- inverted V insert on parabolic drop

- removal of baffle blocks. 
The high-slope fillet insert in front of the end sill was tested and provided a good indication that riprap can be flushed with a lower flow than is possible without the fillet insert. However, the fillet insert does not produce flow behavior that will flush rock at flows released at the project annually, and reaching sufficiently high flows would be difficult.

The low-slope fillet insert in front of the end sill provided the best results. This modification resulted in riprap being flushed out at low flows that the project typically releases annually. Also, rocks of varying sizes were placed within the basin, and all were flushed out at a satisfactory flow.

An inverted $\mathrm{V}$ was installed on the parabolic drop to distribute the flow exiting the conduit in a manner that eliminates an eddy on one side of the stilling basin. Tests with and without the low-slope fillet insert were performed, and the inverted $\mathrm{V}$ provided satisfactory results for flow conditions below $2000 \mathrm{cfs}$. However, at higher cubic feet per second flows, the inverted $\mathrm{V}$ produced more turbulent conditions, and riprap moved downstream from the $36 \mathrm{in}$. riprap zone.

The inverted $\mathrm{V}$ design is primarily intended for projects where the culvert outlet is low for the tailwater that is present. The high tailwater causes the flow exiting the culvert to move to one wall rather than distribute uniformly down the parabolic drop. This results in a horizontal eddy in the stilling basin with low flows, which in most cases is not desirable. The stilling basin design at Sayers works well for the design flow but also results in a horizontal eddy forming in the basin for the lower flows. This eddy results from the basin being oversized for the low flows. Although the eddy is present for the low flows, it would not be a big concern if rock were not in the stilling basin. The flow exiting the stilling basin for the low flows is not turbulent and does not appear to cause any problems in the exit channel.

The baffle blocks in the prototype have been damaged and need repairs; therefore, the baffle blocks were removed in the stilling basin physical model and tested at the request of NAB. Since the current condition of the baffle blocks is badly deteriorated, removing them altogether is practical. Testing revealed that the removal of the baffle blocks causes greatly increased turbulence in the bottom of the stilling basin. The baffle blocks were considered necessary to adequately dissipate the energy of the flow in the stilling basin. 
Of all the design changes tested, the best design change to add into the stilling basin is the low-slope fillet in front of the end sill. This provided the best results for riprap that is entrapped in the basin to be flushed at flows that the project releases annually. Since a design to repair the stilling basin exists, incorporating the design of the low-slope fillet into that design would be advantageous to reduce design and construction costs.

Replacing the riprap immediately downstream from the existing concrete apron with an additional length of concrete had been discussed as a possible plan. The protection blanket would mainly have consisted of a $4 \mathrm{ft}$ thick concrete pad to replace the $36 \mathrm{in}$. zone riprap. Also, a dewatering structure would have to be constructed downstream of the $36 \mathrm{in}$. zone. This construction effort would be very expensive and the concrete would have a tendency to cause scouring issues downstream. Since no movement of the riprap back into the stilling basin was observed, the additional length of concrete from the apron is considered unnecessary. When comparing the concrete riprap protection blanket and the low-slope fillet in front of the end sill, the fillet would likely have lower design and construction costs.

The current design of the Sayers Dam stilling basin is different from what design guidance (HQUSACE 1980) recommends. The design guidance recommends the end sill to be half of the baffle block height. However, at Sayers Dam, the end sill is the same height as the baffle blocks, which is one indication of the tendency of riprap to be trapped in the stilling basin. Also, the fillets at the exit of the culvert should be 1.5 times the size of the culvert, per guidance. However, at Sayers Dam, the fillets are over three times as large as the culvert diameter. As the guidance also explains, for projects with a high tailwater, a back-roller event is possible. Conversely, at Sayers Dam the tailwater stays relatively low, and therefore a back-roller event is not plausible.

\subsection{Recommendation}

Recommendations by ERDC to NAB concerning Foster Joseph Sayers Dam are as follows:

- The primary recommendation by ERDC is to design and construct a low-slope fillet to be placed immediately upstream of the end sill while repairing the remainder of the stilling basin. This would allow riprap that is entrapped within the stilling basin to be flushed at flows 
commonly observed at Sayers Dam and would require minimal, if any, special flushing procedures. Since a design to repair the stilling basin already exists, incorporating a design change for this fillet insert would reduce construction costs. Also, NAB would need to ensure the design is adequate for the low-slope fillet prior to construction. ERDC CHL recommends ERDC Geotechnical and Structures Laboratory to review the design prior to construction. After construction, there would need to be some assessment as to the degree of flushing that occurs with regular annual flows and potentially the need to schedule higher flows in the 3,000 cfs vicinity to accomplish full flushing.

- ERDC recommends having the upper reservoir area, primarily around the gate structure, $3 \mathrm{D}$ lidar scanned to locate any areas around the gate structure that show loss of riprap or scour. This scan could indicate if riprap is being pulled through the gate structure and into the stilling basin. An ERDC CHL team would be able to complete this objective if no other means are available at NAB.

- ERDC recommends methods to prevent vandalism at the project (possibly fencing around the sides of the stilling basin) be investigated to ensure no visitors have the option of throwing riprap into the stilling basin.

- ERDC recommends that the two gates be operated at the same gate elevation. During model testing, when the gates were at different elevations, a large horizontal eddy formed within the stilling basin. To help with turbulent flows within the stilling basin, operating the gates at the same elevation is desired.

- ERDC recommends repairing existing baffle blocks to original specifications to ensure a sufficiently strong hydraulic jump is present. 


\section{References}

Headquarters, U.S. Army Corps of Engineers (HQUSACE). 1980. Hydraulic Design of Reservoir Outlet Works. EM 1110-2-1602. Washington, DC: Headquarters, U.S. Army Corps of Engineers.

HQUSACE. 1994. Hydraulic Design of Flood Control Channels. EM 1110-2-1601. Washington, DC: Headquarters, U.S. Army Corps of Engineers.

U.S. Army Corps of Engineers (USACE), Baltimore District (NAB). 1969. Plans for Outlet Works Gate Structure Blanchard Dam. Bald Eagle Creek, Howard, Pennsylvania, Baltimore District, North Atlantic Division.

USACE NAB. 1996. Master Manual for Reservoir Regulation Susquehanna River Basin. Volume II - Lower Basin, Appendix C. Bald Eagle Creek, Howard, Pennsylvania, Baltimore District, North Atlantic Division.

USACE NAB. 2015. Foster Joseph Sayers Dam Stilling Basin Study, Final Report. Bald Eagle Creek, Howard, Pennsylvania, Baltimore District, North Atlantic Division.

U.S. Army Engineer Waterways Experiment Station (WES). 1977. Corps of Engineers Hydraulic Design Criteria, Vol. 2. Vicksburg, MS: U.S. Army Engineer Waterways Experiment Station. 


\section{Appendix: Testing Notes}

Test 1

\begin{tabular}{|c|c|c|c|c|c|}
\hline Test \# & Prototype CFS & Model CFS & Gate Opening Elevation (ft) & Headwater Elevation (ft) & Tailwater Elevation (ft) \\
\hline 1 & 615 & 0.45 & 591.4 & & \\
\hline
\end{tabular}

\section{Observation}

- Flow inside the basin moves from left to right and can be changed by placing a board in the flow and directing flow to a certain side of the basin.

- Debris in water swirling in bottom of basin.

- Eddy present that starts at hydraulic jump and ends in between baffle block face and end sill.

\section{Test 2}

\begin{tabular}{|c|c|c|c|c|c|}
\hline Test \# & Prototype CFS & Model CFS & Gate Opening Elevation $(\mathrm{ft})$ & Headwater Elevation $(\mathrm{ft})$ & Tailwater Elevation $(\mathrm{ft})$ \\
\hline 2 & 615 & 0.45 & 591.4 & 617.8 & 583.8 \\
\hline
\end{tabular}

\section{$\underline{\text { Observation }}$}

- Same observation as Test 1.

\section{Test 3}

\begin{tabular}{|c|c|c|c|c|c|}
\hline Test \# & Prototype CFS & Model CFS & Gate Opening Elevation $(\mathrm{ft})$ & Headwater Elevation $(\mathrm{ft})$ & Tailwater Elevation $(\mathrm{ft})$ \\
\hline 3 & 615 & 0.45 & 591.4 & 617.8 & 583.2 \\
\hline
\end{tabular}

\section{Observation}

- More waves are present within the exit channel.

- Eddy is not as noticeable with a lower tail water vs. a higher tailwater.

- Toe of the jump looks more uniform.

\section{Test 4}

\begin{tabular}{|c|c|c|c|c|c|}
\hline Test \# & Prototype CFS & Model CFS & Gate Opening Elevation (ft) & Headwater Elevation (ft) & Tailwater Elevation (ft) \\
\hline 4 & 615 & 0.45 & 591.4 & 617.8 & 582.71 \\
\hline
\end{tabular}

\section{Observation}

- Main observation is the tailwater elevation of 582.71 is the elevation at which the exit channel controls the depth of the channel and not the tailgate. 
Test 5

\begin{tabular}{|l|l|l|l|l|l|}
\hline Test \# & Prototype CFS & Model CFS & Gate Opening Elevation (ft) & Headwater Elevation (ft) & Tailwater Elevation (ft) \\
\hline
\end{tabular}

\begin{tabular}{|c|c|c|c|c|c|}
\hline 5 & 615 & 0.45 & 591.4 & 617.8 & 584.5 \\
\hline
\end{tabular}

\section{Observation}

- The eddies within the basin as described in previous tests are less prevalent with the eddy on the left side of the basin slightly larger than the eddy on the right side of the basin.

\section{Test 6}

\begin{tabular}{|c|c|c|c|c|c|}
\hline Test \# & Prototype CFS & Model CFS & Gate Opening Elevation (ft) & Headwater Elevation (ft) & Tailwater Elevation (ft) \\
\hline 6 & 615 & 0.45 & 591.4 & 617.8 & 586.5 \\
\hline
\end{tabular}

\section{Observation}

- Main observation is that the eddy on the right side is much stronger than left side.

\section{Test 7}

\begin{tabular}{|c|c|c|c|c|c|}
\hline Test \# & Prototype CFS & Model CFS & Gate Opening Elevation (ft) & Headwater Elevation (ft) & Tailwater Elevation (ft) \\
\hline 7 & 1000 & 0.73 & 592.25 & 618.3 & 584.7 \\
\hline
\end{tabular}

\section{Observation}

- Eddies present on each side of the stilling basin.

- Flow looks fairly uniform (good).

\section{Test 8}

\begin{tabular}{|c|c|c|c|c|c|}
\hline Test \# & Prototype CFS & Model CFS & Gate Opening Elevation (ft) & Headwater Elevation (ft) & Tailwater Elevation (ft) \\
\hline 8 & 1500 & 1.09 & 593.5 & 619.5 & 584.9 \\
\hline
\end{tabular}

\section{Observation}

- Flow within stilling basin looks uniform throughout the basin.

- Eddies are symmetrical on each side.

- Debris is swirling around on bottom between baffle blocks and knee wall.

- Some small pieces of debris moving upstream on right side of the bottom of the chute.

\footnotetext{
**Note: Tests 1 - 8 were performed with the point gage slightly off. The point gage was reset and checked periodically through the rest of the testing.
} 


\section{Test 9}

\begin{tabular}{|c|c|c|c|c|c|}
\hline Test \# & Prototype CFS & Model CFS & Gate Opening Elevation $(\mathrm{ft})$ & Headwater Elevation $(\mathrm{ft})$ & Tailwater Elevation $(\mathrm{ft})$ \\
\hline 9 & 1500 & 1.09 & 593.5 & 619.5 & 585.8 \\
\hline
\end{tabular}

\section{$\underline{\text { Observation }}$}

- No noticeable change from the observations in Test 8.

\section{Test 10}

\begin{tabular}{|r|c|c|c|c|c|}
\hline Test \# & Prototype CFS & Model CFS & Gate Opening Elevation $(\mathrm{ft})$ & Headwater Elevation $(\mathrm{ft})$ & Tailwater Elevation $(\mathrm{ft})$ \\
\hline 10 & 150 & 0.11 & 590.4 & 610 & 581.25 \\
\hline
\end{tabular}

\section{Observation}

- Very small eddy on left side of basin.

- No debris moving around on the floor of the basin.

- Dropped pea gravel up near the bottom of the exit chute. Observed the gravel did not move. Estimated project stone size of $4.5 \mathrm{in}$.

\section{Test 11}

\begin{tabular}{|r|c|c|c|c|c|}
\hline Test \# & Prototype CFS & Model CFS & Gate Opening Elevation $(\mathrm{ft})$ & Headwater Elevation $(\mathrm{ft})$ & Tailwater Elevation (ft) \\
\hline 11 & 615 & 0.45 & 591.4 & 617.5 & 582.9 \\
\hline
\end{tabular}

\section{Observation}

- Uniform eddy was present on both sides of the basin.

- Debris and small rock did not move on floor of basin.

- Started introducing dye into flow stream as well as recording videos.

\section{Test 12}

\begin{tabular}{|c|c|c|c|c|c|}
\hline Test \# & Prototype CFS & Model CFS & Gate Opening Elevation $(\mathrm{ft})$ & Headwater Elevation $(\mathrm{ft})$ & Tailwater Elevation $(\mathrm{ft})$ \\
\hline 12 & 615 & 0.45 & 591.4 & 617.5 & 583.6 \\
\hline
\end{tabular}

\section{Observation}

- Fairly uniform eddies on each side of the basin with the left eddy slightly larger than the right side.

- Debris and small rock starting to be moved around on the floor of the basin. 
Test 13

\begin{tabular}{|l|l|l|l|l|l|}
\hline Test \# & Prototype CFS & Model CFS & Gate Opening Elevation $(\mathrm{ft})$ & Headwater Elevation $(\mathrm{ft})$ & Tailwater Elevation (ft) \\
\hline
\end{tabular}

\begin{tabular}{|c|c|c|c|c|c|}
\hline 13 & 1000 & 0.73 & 592.25 & 617.5 & 584 \\
\hline
\end{tabular}

\section{Observation}

- The eddy in the stilling basin is moving right to left and is not staying uniform within the basin.

- Starting to see the small rocks being thrown around in the floor of the basin.

\section{Test 14}

\begin{tabular}{|r|c|c|c|c|c|}
\hline Test \# & Prototype CFS & Model CFS & Gate Opening Elevation (ft) & Headwater Elevation (ft) & Tailwater Elevation (ft) \\
\hline 14 & 1000 & 0.73 & 592.25 & 617.5 & 584.7 \\
\hline
\end{tabular}

\section{Observation}

- The eddy on the right side of the basin is not as prevalent as the eddy on the left side of the basin

- Small rocks are still being thrown around on the basin floor.

\section{Test 15}

\begin{tabular}{|r|c|c|c|c|c|}
\hline Test \# & Prototype CFS & Model CFS & Gate Opening Elevation (ft) & Headwater Elevation $(\mathrm{ft})$ & Tailwater Elevation (ft) \\
\hline 15 & 1500 & 1.09 & 593.5 & 619 & 584.9 \\
\hline
\end{tabular}

\section{Observation}

- Same observation as in Test 14.

\section{Test 16}

\begin{tabular}{|r|c|c|c|c|c|}
\hline Test \# & Prototype CFS & Model CFS & Gate Opening Elevation (ft) & Headwater Elevation (ft) & Tailwater Elevation (ft) \\
\hline 16 & 1500 & 1.09 & 593.5 & 619 & 585.8 \\
\hline
\end{tabular}

\section{Observation}

- Same observation as Test 14. 
Test 17

\begin{tabular}{|r|c|c|c|c|c|}
\hline Test \# & Prototype CFS & Model CFS & Gate Opening Elevation $(\mathrm{ft})$ & Headwater Elevation $(\mathrm{ft})$ & Tailwater Elevation $(\mathrm{ft})$ \\
\hline 17 & 2000 & 1.45 & 594.75 & 618 & 585.6 \\
\hline
\end{tabular}

\section{$\underline{\text { Observation }}$}

- Eddies on both sides of stilling basin.

- $\quad$ Boiling up more on left side.

- Rocks are being moved around more greatly and piling toward the right side near the end sill.

\section{Test 18}

\begin{tabular}{|c|c|c|c|c|c|}
\hline Test \# & Prototype CFS & Model CFS & Gate Opening Elevation $(\mathrm{ft})$ & Headwater Elevation $(\mathrm{ft})$ & Tailwater Elevation $(\mathrm{ft})$ \\
\hline 18 & 2000 & 1.45 & 594.75 & 618 & 586.8 \\
\hline
\end{tabular}

\section{$\underline{\text { Observation }}$}

- $\quad$ Same observation as Test 17.

\section{Test 19}

\begin{tabular}{|r|c|c|c|c|c|}
\hline Test \# & Prototype CFS & Model CFS & Gate Opening Elevation (ft) & Headwater Elevation $(\mathrm{ft})$ & Tailwater Elevation $(\mathrm{ft})$ \\
\hline 19 & 2500 & 1.82 & 596 & 618 & 586.3 \\
\hline
\end{tabular}

\section{Observation}

- Boiling up on both sides of the stilling basin.

- Higher exit velocity noticeable toward the end of the basin.

- Eddies pulling flow towards the chute in the middle.

- Rocks still swirling around near the end sill.

\section{Test 20}

\begin{tabular}{|r|c|c|c|c|c|}
\hline Test \# & Prototype CFS & Model CFS & Gate Opening Elevation (ft) & Headwater Elevation (ft) & Tailwater Elevation (ft) \\
\hline 20 & 2500 & 1.82 & 596 & 618 & 587.5 \\
\hline
\end{tabular}

\section{Observation}

- Boiling slightly more on the left side of the basin.

- Higher exit velocity noticeable toward the end of the basin.

- Eddies pulling flow towards the chute in the middle.

- Rocks still swi.rling around near the end sill. 
Test 21

\begin{tabular}{|l|l|l|l|l|l|}
\hline Test \# & Prototype CFS & Model CFS & Gate Opening Elevation $(\mathrm{ft})$ & Headwater Elevation $(\mathrm{ft})$ & Tailwater Elevation $(\mathrm{ft})$ \\
\hline
\end{tabular}

\begin{tabular}{|c|c|c|c|c|c|}
\hline 21 & 3000 & 2.18 & 597.25 & 619.5 & 588.1 \\
\hline
\end{tabular}

\section{Observation}

- More rock moving around between the baffle block and end sill

- More turbulent downstream of the basin.

- Boiling up more on left side of basin.

- Eddies present at top of flow and not bottom.

- Flow at bottom pushing flow downstream more.

\section{Test 22}

\begin{tabular}{|r|c|c|c|c|c|}
\hline Test \# & Prototype CFS & Model CFS & Gate Opening Elevation $(\mathrm{ft})$ & Headwater Elevation $(\mathrm{ft})$ & Tailwater Elevation $(\mathrm{ft})$ \\
\hline 22 & 3000 & 2.18 & 597.25 & 619.5 & 586.8 \\
\hline
\end{tabular}

\section{Observation}

- Same observations as Test 21.

\section{Test 23}

\begin{tabular}{|r|c|c|c|c|c|}
\hline Test \# & Prototype CFS & Model CFS & Gate Opening Elevation $(\mathrm{ft})$ & Headwater Elevation $(\mathrm{ft})$ & Tailwater Elevation $(\mathrm{ft})$ \\
\hline 23 & 3500 & 2.55 & 598.5 & 620.8 & 587.3 \\
\hline
\end{tabular}

\section{Observation}

- Rocks movement increased greatly.

- Very turbulent water in stilling basin now present.

- Boiling up on both side of basin equally

- Pushed large rock from end of up slope downstream $4 \mathrm{ft}$.

\section{Test 24}

\begin{tabular}{|r|c|c|c|c|c|}
\hline Test \# & Prototype CFS & Model CFS & Gate Opening Elevation (ft) & Headwater Elevation (ft) & Tailwater Elevation (ft) \\
\hline 24 & 3500 & 2.55 & 598.5 & 620.8 & 588.6 \\
\hline
\end{tabular}

\section{Observation}

- Same observation as Test 23. 
Test 25

\begin{tabular}{|l|l|l|l|l|l|}
\hline Test \# & Prototype CFS & Model CFS & Gate Opening Elevation $(\mathrm{ft})$ & Headwater Elevation $(\mathrm{ft})$ & Tailwater Elevation $(\mathrm{ft})$ \\
\hline
\end{tabular}

\begin{tabular}{|c|c|c|c|c|c|}
\hline 25 & 4000 & 2.91 & 599.7 & 621.4 & 587.7 \\
\hline
\end{tabular}

\section{Observation}

- Small rock one-quarter to one-half in. diameter was flushed out of the stilling basin and pushed downstream.

- Rocks movement still increasing inside basin.

- Very turbulent waters

- Rocks moving up to sloped side of baffle blocks and then getting violently shot down into basin to end sill.

\section{Test 26}

\begin{tabular}{|r|c|c|c|c|c|}
\hline Test \# & Prototype CFS & Model CFS & Gate Opening Elevation $(\mathrm{ft})$ & Headwater Elevation $(\mathrm{ft})$ & Tailwater Elevation (ft) \\
\hline 26 & 4000 & 2.91 & 599.7 & 621.4 & 589.1 \\
\hline
\end{tabular}

\section{Observation}

- Rocks movement in stilling basin seem to decrease slightly from Test 25 .

\section{Test 27}

\begin{tabular}{|c|c|c|c|c|c|}
\hline Test \# & Prototype CFS & Model CFS & Gate Opening Elevation $(\mathrm{ft})$ & Headwater Elevation $(\mathrm{ft})$ & Tailwater Elevation $(\mathrm{ft})$ \\
\hline 27 & 4500 & 3.27 & 601 & 621.3 & 588.2 \\
\hline
\end{tabular}

\section{Observation}

- Rock one-half in. in diameter pulled out of basin and downstream.

- Rock movement increased in basin.

- Rock shooting fast between baffle blocks as stated in Test 25 .

- Water boiling more over baffles now.

\section{Test 28}

\begin{tabular}{|r|c|c|c|c|c|}
\hline Test \# & Prototype CFS & Model CFS & Gate Opening Elevation (ft) & Headwater Elevation (ft) & Tailwater Elevation (ft) \\
\hline 28 & 4500 & 3.27 & 601 & 621.3 & 589.5 \\
\hline
\end{tabular}

\section{Observation}

- Same observations at Test 27. 


\section{Test 29}

\begin{tabular}{|r|c|c|c|c|c|}
\hline Test \# & Prototype CFS & Model CFS & Gate Opening Elevation (ft) & Headwater Elevation (ft) & Tailwater Elevation (ft) \\
\hline 29 & 5000 & 3.64 & 602.4 & 621.4 & 589.9 \\
\hline
\end{tabular}

\section{$\underline{\text { Observation }}$}

- Water seems to be surging slightly through model.

- Boiling up more past baffle blocks.

- Flow very turbulent in basin.

- Rocks continuing to be thrown around violently in basin.

\section{Test 30}

\begin{tabular}{|r|c|c|c|c|c|}
\hline Test \# & Prototype CFS & Model CFS & Gate Opening Elevation (ft) & Headwater Elevation (ft) & Tailwater Elevation (ft) \\
\hline 30 & 6000 & 4.36 & 605 & 624 & 590.6 \\
\hline
\end{tabular}

\section{Observation}

- Rocks are beginning to be pulled out of the basin towards downstream more frequently.

- Very turbulent water.

- Water still boiling up just downstream of baffles.

- Water starting to roll up on sides of flanges on the exit of the culvert.

\section{Test 31}

\begin{tabular}{|r|c|c|c|c|c|}
\hline Test \# & Prototype CFS & Model CFS & Gate Opening Elevation (ft) & Headwater Elevation (ft) & Tailwater Elevation (ft) \\
\hline 31 & 7000 & 5.09 & 605 & 631.5 & 591.3 \\
\hline
\end{tabular}

\section{$\underline{\text { Observation }}$}

- Many rocks have been flushed out of basin downstream with only a few bigger rocks left.

- Very turbulent water in basin.

- Boiling up high near of wall just past baffle blocks.

- Water starting to splash over sides of exit channel closest to stilling basin. 


\section{Test 32}

\begin{tabular}{|c|c|c|c|c|c|}
\hline Test \# & Prototype CFS & Model CFS & Gate Opening Elevation $(\mathrm{ft})$ & Headwater Elevation $(\mathrm{ft})$ & Tailwater Elevation $(\mathrm{ft})$ \\
\hline 32 & 8000 & 5.82 & 605 & 641.25 & 591.9 \\
\hline
\end{tabular}

\section{Observation}

- All rocks have been flushed out of basin.

- Water boiling high over end sill coving over top of wall.

- Very, very turbulent waters

\section{Test 33}

\begin{tabular}{|r|c|c|c|c|c|}
\hline Test \# & Prototype CFS & Model CFS & Gate Opening Elevation (ft) & Headwater Elevation (ft) & Tailwater Elevation (ft) \\
\hline 33 & 9300 & 6.76 & 605 & 657 & 592.7 \\
\hline
\end{tabular}

\section{Observation}

- No rocks present in basin with very turbulent waters present.

- Water is boiling up past end sill.

- Water splashing out of model has increased greatly.

- Noted that the upper reservoir elevation stopped at $657 \mathrm{ft}$, which equals the emergency spillway crest level.

\section{Test 34}

\begin{tabular}{|r|c|c|c|c|c|}
\hline Test \# & Prototype CFS & Model CFS & Gate Opening Elevation $(\mathrm{ft})$ & Headwater Elevation $(\mathrm{ft})$ & Tailwater Elevation $(\mathrm{ft})$ \\
\hline 34 & 1000 & 0.73 & 591.8 & 630 & 584.7 \\
\hline
\end{tabular}

\section{Observation}

- Eddy present on left side of stilling basin.

- Using dye, eddy goes entire length of the basin on the surface.

- Dye went downstream on right side on surface and bottom of basin.

- $\quad$ No back roller present; used dye at end of concrete apron as well.

- Rock did not move near the end sill; 4 to 6 in. project rock size.

- $\quad$ Rock moving up near parabolic drop outlet and moved down towards baffle blocks. 
Test 35

\begin{tabular}{|l|l|l|l|l|l|}
\hline Test \# & Prototype CFS & Model CFS & Gate Opening Elevation (ft) & Headwater Elevation (ft) & Tailwater Elevation (ft) \\
\hline
\end{tabular}

\begin{tabular}{|c|c|c|c|c|c|}
\hline 35 & 1000 & 0.73 & 591.8 & 630 & 584 \\
\hline
\end{tabular}

Observation

- Larger eddy present on left side.

- No back roller noticed on concrete apron.

- Eddy is shorter on the surface in the basin vs. Test 34.

- Rock 4 to 6 in. project size shot out towards baffle blocks.

- Rock did not move once near the end sill.

\section{Test 36}

\begin{tabular}{|r|c|c|c|c|c|}
\hline Test \# & Prototype CFS & Model CFS & Gate Opening Elevation $(\mathrm{ft})$ & Headwater Elevation $(\mathrm{ft})$ & Tailwater Elevation $(\mathrm{ft})$ \\
\hline 36 & 1000 & 0.73 & 592.5 & 610 & 584 \\
\hline
\end{tabular}

\section{Observation}

- Flow looks fairly uniform with a small eddy on each side.

- Rocks continuing to move downstream from parabolic drop.

- Flow is not as turbulent as it was with $630 \mathrm{ft}$ head water

- No back roller present on concrete apron; dye tested.

\section{Test 37}

\begin{tabular}{|r|c|c|c|c|c|}
\hline Test \# & Prototype CFS & Model CFS & Gate Opening Elevation $(\mathrm{ft})$ & Headwater Elevation $(\mathrm{ft})$ & Tailwater Elevation $(\mathrm{ft})$ \\
\hline 37 & 1000 & 0.73 & 592.5 & 610 & 584.7 \\
\hline
\end{tabular}

\section{Observation}

- Same observations as previous test.

- Eddy is focused more on the right side of the stilling basin.

- Small back roller present near the surface of the water.

- $\quad 582.71 \mathrm{ft}$ elevation in channel is the channel control depth, the depth where the tailgate has no control over the channel water elevation and below. 
Test 38

\begin{tabular}{|l|l|l|l|l|l|}
\hline Test \# & Prototype CFS & Model CFS & Gate Opening Elevation (ft) & Headwater Elevation (ft) & Tailwater Elevation (ft) \\
\hline
\end{tabular}

\begin{tabular}{|c|c|c|c|c|c|}
\hline 38 & 3500 & 2.55 & 597.2 & 630 & 587.3 \\
\hline
\end{tabular}

Observation

- Noticing a strong hydraulic jump just past the end sill.

- Water is boiling up on each side of the basin.

- Rocks are moving around between the baffle and end sill area of the basin.

\section{Test 39}

\begin{tabular}{|r|c|c|c|c|c|}
\hline Test \# & Prototype CFS & Model CFS & Gate Opening Elevation $(\mathrm{ft})$ & Headwater Elevation $(\mathrm{ft})$ & Tailwater Elevation (ft) \\
\hline 39 & 3500 & 2.55 & 597.2 & 630 & 588.6 \\
\hline
\end{tabular}

\section{Observation}

- Same observations as Test 38.

- Noticed while the gates were being changed from Test 38 to Test 39, a large eddy was present in the stilling basin. After further investigation, when the gates are at different elevations, this causes large eddies to form in the basin.

\section{Test 40}

\begin{tabular}{|r|c|c|c|c|c|}
\hline Test \# & Prototype CFS & Model CFS & Gate Opening Elevation (ft) & Headwater Elevation (ft) & Tailwater Elevation (ft) \\
\hline 40 & 3500 & 2.55 & 602 & 610 & 587.3 \\
\hline
\end{tabular}

\section{Observation}

- Hydraulic jump within the stilling basin is acting as it should.

- Small rocks moving around greatly in bottom of basin.

- Larger rocks are not moving around much. 
Test 41

\begin{tabular}{|l|l|l|l|l|l|}
\hline Test \# & Prototype CFS & Model CFS & Gate Opening Elevation (ft) & Headwater Elevation (ft) & Tailwater Elevation (ft) \\
\hline
\end{tabular}

\begin{tabular}{|c|c|c|c|c|c|}
\hline 41 & 1500 & 1.09 & 592.8 & 630 & 584.9 \\
\hline
\end{tabular}

Observation

- Eddies present on both sides of the stilling basin.

- Flow is slightly more to the left which causes a bigger eddy on the right.

- Placed three rows of rocks on the lower apron with three rocks per row. One row closest to the end sill, one row in middle of apron, and one row toward the end of apron next to riprap.

- Left rock closest to the end sill swirled around and moved down into the basin. Two other rocks in middle, one near end sill and one in middle of apron, moved downstream a few inches.

- Rocks were 1.5 in. in diameter.

Test 42

\begin{tabular}{|r|c|c|c|c|c|}
\hline Test \# & Prototype CFS & Model CFS & Gate Opening Elevation $(\mathrm{ft})$ & Headwater Elevation $(\mathrm{ft})$ & Tailwater Elevation $(\mathrm{ft})$ \\
\hline 42 & 1500 & 1.09 & 592.8 & 630 & 585.8 \\
\hline
\end{tabular}

\section{Observation}

- Eddy on left side with the flow concentrated more to the right.

- Flow then moved to the opposite side of the basin with large eddy on the right.

- Two rocks on the first row of apron, near end sill, moved down into the basin. One rock was on left side and one rock was on right side. Middle rock on the same row moved downstream.

- Middle row rock in middle of apron moved downstream.

- When the flow switched from one side to the other is when the corresponding rocks fell into the basin. 


\section{Test 43}

\begin{tabular}{|r|c|c|c|c|c|}
\hline Test \# & Prototype CFS & Model CFS & Gate Opening Elevation $(\mathrm{ft})$ & Headwater Elevation $(\mathrm{ft})$ & Tailwater Elevation $(\mathrm{ft})$ \\
\hline 43 & 1500 & 1.09 & 592.8 left/ 592.3 right & 630 & 585.8 \\
\hline
\end{tabular}

\section{$\underline{\text { Observation }}$}

- $\quad$ Closed the right gate by $0.5 \mathrm{ft}$.

- Large eddy in basin on the right with flow hard to the left wall. After a period of time, flows did move to the right wall.

- Row of rocks near end sill, one on left corner and one on right corner moved down into the basin. Middle rock in the same row swirled around but never moved in basin.

\section{Test 44}

\begin{tabular}{|r|c|c|c|c|c|}
\hline Test \# & Prototype CFS & Model CFS & Gate Opening Elevation (ft) & Headwater Elevation (ft) & Tailwater Elevation (ft) \\
\hline 44 & 1500 & 1.09 & 594.4 & 610 & 585.8 \\
\hline
\end{tabular}

\section{Observation}

- Flow much less turbulent in stilling basin.

- Boiling on both sides of basin with eddies in the middle.

- Rocks did not move on the apron.

\section{Test 45}

\begin{tabular}{|r|c|c|c|c|c|}
\hline Test \# & Prototype CFS & Model CFS & Gate Opening Elevation $(\mathrm{ft})$ & Headwater Elevation $(\mathrm{ft})$ & Tailwater Elevation $(\mathrm{ft})$ \\
\hline 45 & 1500 & 1.09 & 594.4 & 610 & 584.9 \\
\hline
\end{tabular}

\section{$\underline{\text { Observation }}$}

- Same observation as Test 44 .

\section{Test 46}

\begin{tabular}{|r|c|c|c|c|c|}
\hline Test \# & Prototype CFS & Model CFS & Gate Opening Elevation (ft) & Headwater Elevation (ft) & Tailwater Elevation (ft) \\
\hline 46 & 3500 & 2.55 & 596.6 & 630 & 588.6 \\
\hline
\end{tabular}

\section{Observation}

\section{Test 47}

\begin{tabular}{|r|c|c|c|c|c|}
\hline Test \# & Prototype CFS & Model CFS & Gate Opening Elevation $(\mathrm{ft})$ & Headwater Elevation $(\mathrm{ft})$ & Tailwater Elevation $(\mathrm{ft})$ \\
\hline 47 & 3500 & 2.55 & 602 & 612 & 588.6 \\
\hline
\end{tabular}

\section{Observation}


Test 48

\begin{tabular}{|l|l|l|l|l|l|}
\hline Test \# & Prototype CFS & Model CFS & Gate Opening Elevation $(\mathrm{ft})$ & Headwater Elevation $(\mathrm{ft})$ & Tailwater Elevation $(\mathrm{ft})$ \\
\hline
\end{tabular}

\begin{tabular}{|c|c|c|c|c|c|}
\hline 48 & 2000 & 1.45 & 594 & 630 & 586.8 \\
\hline
\end{tabular}

\section{Observation}

\section{Test 49}

\begin{tabular}{|r|c|c|c|c|c|}
\hline Test \# & Prototype CFS & Model CFS & Gate Opening Elevation (ft) & Headwater Elevation (ft) & Tailwater Elevation (ft) \\
\hline 49 & 2000 & 1.45 & 594 & 630 & 586.8 \\
\hline
\end{tabular}

\section{Observation}

\section{Test 50}

\begin{tabular}{|r|c|c|c|c|c|}
\hline Test \# & Prototype CFS & Model CFS & Gate Opening Elevation (ft) & Headwater Elevation (ft) & Tailwater Elevation (ft) \\
\hline 50 & 2000 & 1.45 & 594 & 630 & 586.8 \\
\hline
\end{tabular}

\section{Observation}

\section{Test 51}

\begin{tabular}{|r|c|c|c|c|c|}
\hline Test \# & Prototype CFS & Model CFS & Gate Opening Elevation (ft) & Headwater Elevation (ft) & Tailwater Elevation (ft) \\
\hline 51 & 3000 & 2.18 & 595.9 & 630 & 588.1 \\
\hline
\end{tabular}

Observation: Placed 45-degree fillet in front of end sill. Small rock flushed out with larger rock still present. Rock that was placed in basin had 18 in. gradation criteria.

\section{Test 52}

\begin{tabular}{|r|c|c|c|c|c|}
\hline Test \# & Prototype CFS & Model CFS & Gate Opening Elevation (ft) & Headwater Elevation (ft) & Tailwater Elevation (ft) \\
\hline 52 & 3000 & 2.18 & 595.9 & 630 & 586.8 \\
\hline
\end{tabular}

Observation: Same observation as previous test.

\section{Test 53}

\begin{tabular}{|r|c|c|c|c|c|}
\hline Test \# & Prototype CFS & Model CFS & Gate Opening Elevation $(\mathrm{ft})$ & Headwater Elevation $(\mathrm{ft})$ & Tailwater Elevation $(\mathrm{ft})$ \\
\hline 53 & 150 & 0.11 & 590.2 & 630 & Low Tailwater \\
\hline
\end{tabular}

\section{Observation: No rock movement from upstream approach channel area.}

\section{Test 54}

\begin{tabular}{|c|c|c|c|c|c|}
\hline Test \# & Prototype CFS & Model CFS & Gate Opening Elevation (ft) & Headwater Elevation (ft) & Tailwater Elevation (ft) \\
\hline 54 & 615 & 0.45 & 591.15 & 630 & Low Tailwater \\
\hline
\end{tabular}

Observation: No rock movement from upstream approach channel area. 


\section{Test 55}

\begin{tabular}{|r|c|c|c|c|c|}
\hline Test \# & Prototype CFS & Model CFS & Gate Opening Elevation (ft) & Headwater Elevation (ft) & Tailwater Elevation (ft) \\
\hline 55 & 1000 & 0.73 & 591.85 & 630 & Low Tailwater \\
\hline
\end{tabular}

Observation: No rock movement from upstream approach channel area.

\section{Test 56}

\begin{tabular}{|c|c|c|c|c|c|}
\hline Test \# & Prototype CFS & Model CFS & Gate Opening Elevation $(\mathrm{ft})$ & Headwater Elevation $(\mathrm{ft})$ & Tailwater Elevation $(\mathrm{ft})$ \\
\hline 56 & 1500 & 1.09 & 592.9 & 630 & Low Tailwater \\
\hline
\end{tabular}

Observation: No rock movement from upstream approach channel area.

\section{Test 57}

\begin{tabular}{|r|c|c|c|c|c|}
\hline Test \# & Prototype CFS & Model CFS & Gate Opening Elevation $(\mathrm{ft})$ & Headwater Elevation $(\mathrm{ft})$ & Tailwater Elevation $(\mathrm{ft})$ \\
\hline 57 & 2000 & 1.45 & 593.9 & 630 & Low Tailwater \\
\hline
\end{tabular}

Observation: No rock movement from upstream approach channel area.

\section{Test 58}

\begin{tabular}{|r|c|c|c|c|c|}
\hline Test \# & Prototype CFS & Model CFS & Gate Opening Elevation (ft) & Headwater Elevation (ft) & Tailwater Elevation (ft) \\
\hline 58 & 2500 & 1.82 & 595 & 630 & Low Tailwater \\
\hline
\end{tabular}

Observation: No rock movement from upstream approach channel area.

\section{Test 59}

\begin{tabular}{|r|c|c|c|c|c|}
\hline Test \# & Prototype CFS & Model CFS & Gate Opening Elevation $(\mathrm{ft})$ & Headwater Elevation $(\mathrm{ft})$ & Tailwater Elevation $(\mathrm{ft})$ \\
\hline 59 & 3000 & 2.18 & 596 & 630 & Low Tailwater \\
\hline
\end{tabular}

Observation: No rock movement from upstream approach channel area.

\section{Test 60}

\begin{tabular}{|r|c|c|c|c|c|}
\hline Test \# & Prototype CFS & Model CFS & Gate Opening Elevation $(\mathrm{ft})$ & Headwater Elevation $(\mathrm{ft})$ & Tailwater Elevation $(\mathrm{ft})$ \\
\hline 60 & 3500 & 2.55 & 597 & 630 & Low Tailwater \\
\hline
\end{tabular}

Observation: No rock movement from upstream approach channel area.

\section{Test 61}

\begin{tabular}{|r|c|c|c|c|c|}
\hline Test \# & Prototype CFS & Model CFS & Gate Opening Elevation $(\mathrm{ft})$ & Headwater Elevation $(\mathrm{ft})$ & Tailwater Elevation $(\mathrm{ft})$ \\
\hline 61 & 4000 & 2.91 & 598.1 & 630 & Low Tailwater \\
\hline
\end{tabular}

Observation: No rock movement from upstream approach channel area. 


\section{Test 62}

\begin{tabular}{|r|c|c|c|c|c|}
\hline Test \# & Prototype CFS & Model CFS & Gate Opening Elevation $(\mathrm{ft})$ & Headwater Elevation $(\mathrm{ft})$ & Tailwater Elevation $(\mathrm{ft})$ \\
\hline 62 & 150 & 0.11 & 590.3 & 610 & Low Tailwater \\
\hline
\end{tabular}

Observation: No rock movement from upstream approach channel area.

\section{Test 63}

\begin{tabular}{|c|c|c|c|c|c|}
\hline Test \# & Prototype CFS & Model CFS & Gate Opening Elevation $(\mathrm{ft})$ & Headwater Elevation $(\mathrm{ft})$ & Tailwater Elevation $(\mathrm{ft})$ \\
\hline 63 & 615 & 0.45 & 591.7 & 610 & Low Tailwater \\
\hline
\end{tabular}

Observation: No rock movement from upstream approach channel area.

\section{Test 64}

\begin{tabular}{|r|c|c|c|c|c|}
\hline Test \# & Prototype CFS & Model CFS & Gate Opening Elevation $(\mathrm{ft})$ & Headwater Elevation $(\mathrm{ft})$ & Tailwater Elevation $(\mathrm{ft})$ \\
\hline 64 & 1000 & 0.73 & 592.7 & 610 & Low Tailwater \\
\hline
\end{tabular}

Observation: No rock movement from upstream approach channel area.

\section{Test 65}

\begin{tabular}{|r|c|c|c|c|c|}
\hline Test \# & Prototype CFS & Model CFS & Gate Opening Elevation (ft) & Headwater Elevation (ft) & Tailwater Elevation (ft) \\
\hline 65 & 1500 & 1.09 & 594.25 & 610 & Low Tailwater \\
\hline
\end{tabular}

Observation: No rock movement from upstream approach channel area.

\section{Test 66}

\begin{tabular}{|r|c|c|c|c|c|}
\hline Test \# & Prototype CFS & Model CFS & Gate Opening Elevation $(\mathrm{ft})$ & Headwater Elevation $(\mathrm{ft})$ & Tailwater Elevation $(\mathrm{ft})$ \\
\hline 66 & 2000 & 1.45 & 596.05 & 610 & Low Tailwater \\
\hline
\end{tabular}

Observation: No rock movement from upstream approach channel area.

\section{Test 67}

\begin{tabular}{|c|c|c|c|c|c|}
\hline Test \# & Prototype CFS & Model CFS & Gate Opening Elevation (ft) & Headwater Elevation (ft) & Tailwater Elevation (ft) \\
\hline 67 & 2500 & 1.82 & 597.75 & 610 & Low Tailwater \\
\hline
\end{tabular}

Observation: No rock movement from upstream approach channel area.

\section{Test 68}

\begin{tabular}{|r|c|c|c|c|c|}
\hline Test \# & Prototype CFS & Model CFS & Gate Opening Elevation $(\mathrm{ft})$ & Headwater Elevation $(\mathrm{ft})$ & Tailwater Elevation $(\mathrm{ft})$ \\
\hline 68 & 3000 & 2.18 & 600 & 610 & Low Tailwater \\
\hline
\end{tabular}

Observation: A few rocks were pulled through the gate structure and into the stilling basin. 


\section{Test 74}

\begin{tabular}{|l|l|l|l|l|l|}
\hline Test \# & Prototype CFS & Model CFS & Gate Opening Elevation (ft) & Headwater Elevation (ft) & Tailwater Elevation (ft) \\
\hline
\end{tabular}

\begin{tabular}{r|c|c|c|c|c|}
\hline 74 & 4000 & 2.91 & 605 & 612 & Low Tailwater \\
\hline
\end{tabular}

Observation: No rock movement from upstream approach channel area.

\section{Test 75}

\begin{tabular}{|r|c|c|c|c|c|}
\hline Test \# & Prototype CFS & Model CFS & Gate Opening Elevation (ft) & Headwater Elevation (ft) & Tailwater Elevation (ft) \\
\hline 75 & 150 & 0.11 & 590.3 & 630 & 581.8 \\
\hline
\end{tabular}

\section{Observation}

- First test with movable bed for exit channel.

- Irregular flow with flow associated with the right side of the basin.

- Flow however is very low in velocity and no turbulence in the bottom of the basin.

- No rock movement in exit channel.

\section{Test 76}

\begin{tabular}{|r|c|c|c|c|c|}
\hline Test \# & Prototype CFS & Model CFS & Gate Opening Elevation (ft) & Headwater Elevation (ft) & Tailwater Elevation (ft) \\
\hline 76 & 150 & 0.11 & 590.3 & 630 & 581.25 \\
\hline
\end{tabular}

\section{Observation}

- Same observation as previous test.

\section{Test 77}

\begin{tabular}{|c|c|c|c|c|c|}
\hline Test \# & Prototype CFS & Model CFS & Gate Opening Elevation $(\mathrm{ft})$ & Headwater Elevation $(\mathrm{ft})$ & Tailwater Elevation $(\mathrm{ft})$ \\
\hline 77 & 615 & 0.45 & 591.25 & 630 & 583.6 \\
\hline
\end{tabular}

\section{Observation}

- Irregular flow with flow associated to the right side of the basin.

- Larger eddy forming within the basin due to irregular flow.

- No rock movement in exit channel. 
Test 78

\begin{tabular}{|c|c|c|c|c|c|}
\hline Test \# & Prototype CFS & Model CFS & Gate Opening Elevation $(\mathrm{ft})$ & Headwater Elevation $(\mathrm{ft})$ & Tailwater Elevation $(\mathrm{ft})$ \\
\hline 78 & 615 & 0.45 & 591.25 & 630 & 582.9 \\
\hline
\end{tabular}

\section{Observation}

- Irregular flow with flow on left side of basin.

- Eddy formed due to irregular flow.

- No rock movement of rocks in exit channel.

\section{Test 79}

\begin{tabular}{|r|c|c|c|c|c|}
\hline Test \# & Prototype CFS & Model CFS & Gate Opening Elevation $(\mathrm{ft})$ & Headwater Elevation $(\mathrm{ft})$ & Tailwater Elevation $(\mathrm{ft})$ \\
\hline 79 & 1000 & 0.73 & 591.8 & 630 & 584.7 \\
\hline
\end{tabular}

\section{Observation}

- Irregular flow on left side of basin.

- Flow is becoming slightly more turbulent in basin.

- No rock movement in exit channel.

\section{Test 80}

\begin{tabular}{|r|c|c|c|c|c|}
\hline Test \# & Prototype CFS & Model CFS & Gate Opening Elevation $(\mathrm{ft})$ & Headwater Elevation $(\mathrm{ft})$ & Tailwater Elevation $(\mathrm{ft})$ \\
\hline 80 & 1000 & 0.73 & 591.8 & 630 & 584 \\
\hline
\end{tabular}

\section{Observation}

- Same observation as previous test.

\section{Test 81}

\begin{tabular}{|r|c|c|c|c|c|}
\hline Test \# & Prototype CFS & Model CFS & Gate Opening Elevation $(\mathrm{ft})$ & Headwater Elevation $(\mathrm{ft})$ & Tailwater Elevation $(\mathrm{ft})$ \\
\hline 81 & 1500 & 1.09 & 592.8 & 630 & 585.8 \\
\hline
\end{tabular}

\section{$\underline{\text { Observation }}$}

- Irregular flow on left side of basin.

- Larger eddy present in basin.

- No rock movement in exit channel.

- Flow is oscillating slightly and moved more towards center of basin. 


\section{Test 82}

\begin{tabular}{|r|c|c|c|c|c|}
\hline Test \# & Prototype CFS & Model CFS & Gate Opening Elevation $(\mathrm{ft})$ & Headwater Elevation $(\mathrm{ft})$ & Tailwater Elevation $(\mathrm{ft})$ \\
\hline 82 & 1500 & 1.09 & 592.8 & 630 & 584.9 \\
\hline
\end{tabular}

\section{Observation}

- Flow is oscillating left to right in basin.

- No rock movement in exit channel.

\section{Test 83}

\begin{tabular}{|r|c|c|c|c|c|}
\hline Test \# & Prototype CFS & Model CFS & Gate Opening Elevation $(\mathrm{ft})$ & Headwater Elevation $(\mathrm{ft})$ & Tailwater Elevation $(\mathrm{ft})$ \\
\hline 83 & 2000 & 1.45 & 593.9 & 630 & 586.8 \\
\hline
\end{tabular}

\section{Observation}

- Flow is more centered in the stilling basin.

- Boiling up near the downstream side of the baffle blocks.

- No rock movement in exit channel.

\section{Test 84}

\begin{tabular}{|r|c|c|c|c|c|}
\hline Test \# & Prototype CFS & Model CFS & Gate Opening Elevation (ft) & Headwater Elevation (ft) & Tailwater Elevation (ft) \\
\hline 84 & 2000 & 1.45 & 593.9 & 630 & 585.6 \\
\hline
\end{tabular}

\section{Observation}

- Same observation as previous test.

\section{Test 85}

\begin{tabular}{|r|c|c|c|c|c|}
\hline Test \# & Prototype CFS & Model CFS & Gate Opening Elevation $(\mathrm{ft})$ & Headwater Elevation $(\mathrm{ft})$ & Tailwater Elevation (ft) \\
\hline 85 & 2500 & 1.82 & 595 & 630 & 587.5 \\
\hline
\end{tabular}

\section{Observation}

- Flow congregated evenly in the middle of the basin.

- Boiling up just past the end sill.

- One rock slightly shaking about 2 in. past the end of the concrete apron. 
Test 86

\begin{tabular}{|c|c|c|c|c|c|}
\hline Test \# & Prototype CFS & Model CFS & Gate Opening Elevation $(\mathrm{ft})$ & Headwater Elevation $(\mathrm{ft})$ & Tailwater Elevation $(\mathrm{ft})$ \\
\hline 86 & 2500 & 1.82 & 595 & 630 & 586.3 \\
\hline
\end{tabular}

\section{Observation}

- Flow in the middle of the stilling basin.

- Boiling just past end sill.

- Rock that was shaking in previous test settled down further and quit shaking.

\section{Test 87}

\begin{tabular}{|r|c|c|c|c|c|}
\hline Test \# & Prototype CFS & Model CFS & Gate Opening Elevation (ft) & Headwater Elevation (ft) & Tailwater Elevation (ft) \\
\hline 87 & 3000 & 2.18 & 596 & 630 & 588.1 \\
\hline
\end{tabular}

\section{Observation}

- Flow in the middle of the stilling basin.

- Still boiling up past the end sill.

- No rock movement in exit channel.

\section{Test 88}

\begin{tabular}{|r|c|c|c|c|c|}
\hline Test \# & Prototype CFS & Model CFS & Gate Opening Elevation (ft) & Headwater Elevation (ft) & Tailwater Elevation (ft) \\
\hline 88 & 3000 & 2.18 & 596 & 630 & 586.8 \\
\hline
\end{tabular}

\section{Observation}

- Same observation as previous test.

\section{Test 89}

\begin{tabular}{|r|c|c|c|c|c|}
\hline Test \# & Prototype CFS & Model CFS & Gate Opening Elevation $(\mathrm{ft})$ & Headwater Elevation $(\mathrm{ft})$ & Tailwater Elevation $(\mathrm{ft})$ \\
\hline 89 & 3500 & 2.55 & 597 & 630 & 588.6 \\
\hline
\end{tabular}

\section{Observation}

- Flow looks pretty uniform and boiling up both sides of the basin.

- Also boiling up past the end sill.

- No rock movement in exit channel. 
Test 90

\begin{tabular}{|r|c|c|c|c|c|}
\hline Test \# & Prototype CFS & Model CFS & Gate Opening Elevation $(\mathrm{ft})$ & Headwater Elevation $(\mathrm{ft})$ & Tailwater Elevation $(\mathrm{ft})$ \\
\hline 90 & 3500 & 2.55 & 597 & 630 & 587.3 \\
\hline
\end{tabular}

\section{$\underline{\text { Observation }}$}

- Same observation as previous test.

\section{Test 91}

\begin{tabular}{|r|c|c|c|c|c|}
\hline Test \# & Prototype CFS & Model CFS & Gate Opening Elevation $(\mathrm{ft})$ & Headwater Elevation $(\mathrm{ft})$ & Tailwater Elevation $(\mathrm{ft})$ \\
\hline 91 & 4000 & 2.91 & 598.1 & 630 & 589.1 \\
\hline
\end{tabular}

\section{Observation}

- Same observation as previous test.

\section{Test 92}

\begin{tabular}{|r|c|c|c|c|c|}
\hline Test \# & Prototype CFS & Model CFS & Gate Opening Elevation $(\mathrm{ft})$ & Headwater Elevation $(\mathrm{ft})$ & Tailwater Elevation $(\mathrm{ft})$ \\
\hline 92 & 4000 & 2.91 & 598.1 & 630 & 587.7 \\
\hline
\end{tabular}

\section{$\underline{\text { Observation }}$}

- Same observation as previous tests.

\section{Test 93}

\begin{tabular}{|r|c|c|c|c|c|}
\hline Test \# & Prototype CFS & Model CFS & Gate Opening Elevation (ft) & Headwater Elevation (ft) & Tailwater Elevation (ft) \\
\hline 93 & 4500 & 3.27 & 599.15 & 630 & 589.5 \\
\hline
\end{tabular}

\section{Observation}

- Uniform flow in basin.

- Boiling up about halfway up concrete apron.

- No rock movement in exit channel.

\section{Test 94}

\begin{tabular}{|r|c|c|c|c|c|}
\hline Test \# & Prototype CFS & Model CFS & Gate Opening Elevation $(\mathrm{ft})$ & Headwater Elevation $(\mathrm{ft})$ & Tailwater Elevation $(\mathrm{ft})$ \\
\hline 94 & 4500 & 3.27 & 599.15 & 630 & 588.2 \\
\hline
\end{tabular}

\section{Observation}

- Same observation as previous test. 
Test 95

\begin{tabular}{|r|c|c|c|c|c|}
\hline Test \# & Prototype CFS & Model CFS & Gate Opening Elevation $(\mathrm{ft})$ & Headwater Elevation $(\mathrm{ft})$ & Tailwater Elevation $(\mathrm{ft})$ \\
\hline 95 & 5000 & 3.64 & 600.2 & 630 & 589.9 \\
\hline
\end{tabular}

\section{$\underline{\text { Observation }}$}

- Flow starting to become more turbulent but still is uniform.

- Boiling up toward the end of the concrete apron.

- No rock movement in exit channel.

\section{Test 96}

\begin{tabular}{|r|c|c|c|c|c|}
\hline Test \# & Prototype CFS & Model CFS & Gate Opening Elevation $(\mathrm{ft})$ & Headwater Elevation $(\mathrm{ft})$ & Tailwater Elevation (ft) \\
\hline 96 & 5000 & 3.64 & 600.2 & 630 & 588.5 \\
\hline
\end{tabular}

\section{Observation}

- Same observation as previous test.

\section{Test 97}

\begin{tabular}{|r|c|c|c|c|c|}
\hline Test \# & Prototype CFS & Model CFS & Gate Opening Elevation $(\mathrm{ft})$ & Headwater Elevation $(\mathrm{ft})$ & Tailwater Elevation (ft) \\
\hline 97 & 5000 & 3.64 & 605 & 618 & 588.5 \\
\hline
\end{tabular}

\section{$\underline{\text { Observation }}$}

- Uniform flow boiling up both sides of basin.

- Few rocks fell down side slopes of exit channel about $8 \mathrm{ft}$ from end of concrete apron.

- One small rock in 36 in. zone shaking around but eventually settled down.

\section{Test 98}

\begin{tabular}{|r|c|c|c|c|c|}
\hline Test \# & Prototype CFS & Model CFS & Gate Opening Elevation $(\mathrm{ft})$ & Headwater Elevation $(\mathrm{ft})$ & Tailwater Elevation $(\mathrm{ft})$ \\
\hline 98 & 5000 & 3.64 & 605 & 618 & 589.9 \\
\hline
\end{tabular}

\section{Observation}

- Same observation as previous test.

- A couple more rocks shaking slightly in 36 in. zone but are not moving upstream or downstream. 
Test 99

\begin{tabular}{|c|c|c|c|c|c|}
\hline Test \# & Prototype CFS & Model CFS & Gate Opening Elevation (ft) & Headwater Elevation (ft) & Tailwater Elevation (ft) \\
\hline
\end{tabular}

\begin{tabular}{l|l|l|l|l|r|}
99 & 4500 & 3.27 & 605 & 615 & 588.2 \\
\hline
\end{tabular}

Observation

- Uniform flow in basin.

- No rock movement in exit channel.

Test 100

\begin{tabular}{|l|c|c|c|c|c|}
\hline Test \# & Prototype CFS & Model CFS & Gate Opening Elevation (ft) & Headwater Elevation (ft) & Tailwater Elevation (ft) \\
\hline
\end{tabular}

\begin{tabular}{|l|l|l|l|l|l}
100 & 4500 & 3.27 & 605 & 615 & 589.5
\end{tabular}

\section{Observation}

- Not as turbulent as previous test with higher headwater.

Test 101

\begin{tabular}{|c|c|c|c|c|c|}
\hline Test \# & Prototype CFS & Model CFS & Gate Opening Elevation $(\mathrm{ft})$ & Headwater Elevation $(\mathrm{ft})$ & Tailwater Elevation $(\mathrm{ft})$ \\
\hline 101 & 4000 & 2.91 & 612 & 612 & 587.7 \\
\hline
\end{tabular}

\section{Observation}

- Same observations as previous tests.

- Since no rock movement took place, no reason to continue tests with less flow since no rock moved with 4500 and 5000 cfs flows.

\section{Test 102}

\begin{tabular}{|c|c|c|c|c|c|}
\hline Test \# & Prototype CFS & Model CFS & Gate Opening Elevation $(\mathrm{ft})$ & Headwater Elevation $(\mathrm{ft})$ & Tailwater Elevation (ft) \\
\hline 102 & 1500 & 1.09 & L592.8/R592.2 & 630 & 585.8 \\
\hline
\end{tabular}

\section{Observation}

- Tested different gate elevations and how it affects flow in basin.

- Created very large eddy in basin but no rock moved in exit channel. 
Test 103

\begin{tabular}{|c|c|c|c|c|c|}
\hline Test \# & Prototype CFS & Model CFS & Gate Opening Elevation $(\mathrm{ft})$ & Headwater Elevation $(\mathrm{ft})$ & Tailwater Elevation $(\mathrm{ft})$ \\
\hline 103 & 1500 & 1.09 & 593 & 630 & 585.8 \\
\hline
\end{tabular}

\section{Observation}

- Removed 36 in. gradation stone and replaced and doubled 18 in. gradation stone in 36 inch gradation area.

- No rock movement in exit channel.

\section{Test 104}

\begin{tabular}{|c|c|c|c|c|c|}
\hline Test \# & Prototype CFS & Model CFS & Gate Opening Elevation $(\mathrm{ft})$ & Headwater Elevation $(\mathrm{ft})$ & Tailwater Elevation $(\mathrm{ft})$ \\
\hline 104 & 2500 & 1.82 & 595 & 630 & 587.5 \\
\hline
\end{tabular}

\section{Observation}

- No rock movement in exit channel.

\section{Test 105}

\begin{tabular}{|c|c|c|c|c|c|}
\hline Test \# & Prototype CFS & Model CFS & Gate Opening Elevation $(\mathrm{ft})$ & Headwater Elevation $(\mathrm{ft})$ & Tailwater Elevation (ft) \\
\hline 105 & 2500 & 1.82 & 595 & 630 & 588.5 \\
\hline
\end{tabular}

\section{Observation}

- Increased tailwater elevation by $1 \mathrm{ft}$ and had no rock movement in exit channel.

\section{Test 106}

\begin{tabular}{|c|c|c|c|c|c|}
\hline Test \# & Prototype CFS & Model CFS & Gate Opening Elevation $(\mathrm{ft})$ & Headwater Elevation $(\mathrm{ft})$ & Tailwater Elevation (ft) \\
\hline 106 & 2500 & 1.82 & 595 & 630 & 589.5 \\
\hline
\end{tabular}

\section{Observation}

- Increased tailwater elevation by $1 \mathrm{ft}$ and had no rock movement in exit channel.

\section{Test 107}

\begin{tabular}{|c|c|c|c|c|c|}
\hline Test \# & Prototype CFS & Model CFS & Gate Opening Elevation (ft) & Headwater Elevation (ft) & Tailwater Elevation (ft) \\
\hline 107 & 3500 & 2.55 & 597 & 630 & 588.6 \\
\hline
\end{tabular}

\section{Observation}

- No rock movement in exit channel. 


\section{Test 108}

\begin{tabular}{|c|c|c|c|c|c|}
\hline Test \# & Prototype CFS & Model CFS & Gate Opening Elevation $(\mathrm{ft})$ & Headwater Elevation $(\mathrm{ft})$ & Tailwater Elevation $(\mathrm{ft})$ \\
\hline 108 & 3500 & 2.55 & 597 & 630 & 589.6 \\
\hline
\end{tabular}

\section{Observation}

- No rock movement in exit channel.

\section{Test 109}

\begin{tabular}{|c|c|c|c|c|c|}
\hline Test \# & Prototype CFS & Model CFS & Gate Opening Elevation $(\mathrm{ft})$ & Headwater Elevation $(\mathrm{ft})$ & Tailwater Elevation $(\mathrm{ft})$ \\
\hline 109 & 3500 & 2.55 & 597 & 630 & 590.6 \\
\hline
\end{tabular}

\section{Observation}

- No rock movement in exit channel.

\section{Test 110}

\begin{tabular}{|c|c|c|c|c|c|}
\hline Test \# & Prototype CFS & Model CFS & Gate Opening Elevation (ft) & Headwater Elevation (ft) & Tailwater Elevation (ft) \\
\hline 110 & 3500 & 2.55 & 597 & 630 & 587.3 \\
\hline
\end{tabular}

\section{$\underline{\text { Observation }}$}

- No rock movement in exit channel.

\section{Test 111}

\begin{tabular}{|c|c|c|c|c|c|}
\hline Test \# & Prototype CFS & Model CFS & Gate Opening Elevation (ft) & Headwater Elevation (ft) & Tailwater Elevation (ft) \\
\hline 111 & 3500 & 2.55 & 597 & 630 & 586.3 \\
\hline
\end{tabular}

\section{Observation}

- No rock movement in exit channel.

\section{Test 112}

\begin{tabular}{|c|c|c|c|c|c|}
\hline Test \# & Prototype CFS & Model CFS & Gate Opening Elevation $(\mathrm{ft})$ & Headwater Elevation $(\mathrm{ft})$ & Tailwater Elevation $(\mathrm{ft})$ \\
\hline 112 & 5000 & 3.64 & 600.1 & 630 & 589.9 \\
\hline
\end{tabular}

\section{$\underline{\text { Observation }}$}

- No rock movement in exit channel. 
Test 113

\begin{tabular}{|c|c|c|c|c|c|}
\hline Test \# & Prototype CFS & Model CFS & Gate Opening Elevation $(\mathrm{ft})$ & Headwater Elevation $(\mathrm{ft})$ & Tailwater Elevation $(\mathrm{ft})$ \\
\hline 113 & 150 & 0.11 & 590.3 & 630 & 581.8 \\
\hline
\end{tabular}

Observation

- No rock movement in exit channel.

\section{Test 114}

\begin{tabular}{|c|c|c|c|c|c|}
\hline Test \# & Prototype CFS & Model CFS & Gate Opening Elevation (ft) & Headwater Elevation $(\mathrm{ft})$ & Tailwater Elevation $(\mathrm{ft})$ \\
\hline 114 & 615 & 0.45 & 591.25 & 630 & 583.6 \\
\hline
\end{tabular}

\section{Observation}

- No rock movement in exit channel.

- Irregular flow with flow on right side of basin.

\section{Test 115}

\begin{tabular}{|c|c|c|c|c|c|}
\hline Test \# & Prototype CFS & Model CFS & Gate Opening Elevation $(\mathrm{ft})$ & Headwater Elevation $(\mathrm{ft})$ & Tailwater Elevation $(\mathrm{ft})$ \\
\hline 115 & 1000 & 0.73 & 591.8 & 630 & 584.7 \\
\hline
\end{tabular}

\section{Observation}

- No rock movement in exit channel.

Test 116

\begin{tabular}{|c|c|c|c|c|c|}
\hline Test \# & Prototype CFS & Model CFS & Gate Opening Elevation (ft) & Headwater Elevation (ft) & Tailwater Elevation (ft) \\
\hline 116 & $1000 / 2000$ & $0.73 / 1.45$ & $591.8 / 594.75$ (1 gate) & 630 & 584.7 \\
\hline
\end{tabular}

\section{Observation}

- Increasing cubic feet per second from 1000 to 2000 and then making a gate change with only one gate. Created large eddy in basin.

- No rock movement in exit channel. 
Test 117

\begin{tabular}{|c|c|c|c|c|c|}
\hline Test \# & Prototype CFS & Model CFS & Gate Opening Elevation $(\mathrm{ft})$ & Headwater Elevation $(\mathrm{ft})$ & Tailwater Elevation $(\mathrm{ft})$ \\
\hline 117 & 1000 inc. & $0.73 / 1.46$ & 591.8 & 630 & 584.7 \\
\hline
\end{tabular}

\section{$\underline{\text { Observation }}$}

- Increasing cubic feet per second from 1000 to 2000 and then making a gate change with only one gate. Created large eddy in basin. Repeated previous test.

- No rock movement in exit channel.

\section{Test 118}

\begin{tabular}{|c|c|c|c|c|c|}
\hline Test \# & Prototype CFS & Model CFS & Gate Opening Elevation $(\mathrm{ft})$ & Headwater Elevation $(\mathrm{ft})$ & Tailwater Elevation $(\mathrm{ft})$ \\
\hline 118 & $3500 / 2000$ & $2.55 / 1.45$ & $597 / 594.75(1$ gate) & 642 & 584.7 \\
\hline
\end{tabular}

\section{Observation}

- Decreasing cubic feet per second from 3,500 to 2,000 and then making a gate change with only one gate. Created large eddy in basin.

- Few rocks shook around slightly but never moved upstream or downstream.

\section{Test 119}

\begin{tabular}{|c|c|c|c|c|c|}
\hline Test \# & Prototype CFS & Model CFS & Gate Opening Elevation (ft) & Headwater Elevation (ft) & Tailwater Elevation (ft) \\
\hline 119 & 2000 & 1.45 & 594.75 (close 1 gate down) & 630 & 585.6 \\
\hline
\end{tabular}

\section{Observation}

- Closed one gate. Large eddy formed.

- No rock movement in exit channel.

\section{Test 120}

\begin{tabular}{|c|c|c|c|c|c|}
\hline Test \# & Prototype CFS & Model CFS & Gate Opening Elevation $(\mathrm{ft})$ & Headwater Elevation $(\mathrm{ft})$ & Tailwater Elevation (ft) \\
\hline 120 & 2000 & 1.45 & 1 gate only at 597.8 & 630 & 585.6 \\
\hline
\end{tabular}

\section{$\underline{\text { Observation }}$}

- One gate all the way closed with second gate twice as open. Large eddy formed. Ran for 1 hour.

- No rock movement in exit channel. 
Test 121

\begin{tabular}{|c|c|c|c|c|c|}
\hline Test \# & Prototype CFS & Model CFS & Gate Opening Elevation $(\mathrm{ft})$ & Headwater Elevation $(\mathrm{ft})$ & Tailwater Elevation $(\mathrm{ft})$ \\
\hline 121 & 3000 & 2.18 & 1 gate only at 602 & 630 & 588.1 \\
\hline
\end{tabular}

Observation

- One gate all the way closed with second gate twice as open. Large eddy formed.

- Flow looks pretty uniform with no eddy present.

- No rock movement in exit channel.

Test 122

\begin{tabular}{|c|c|c|c|c|c|}
\hline Test \# & Prototype CFS & Model CFS & Gate Opening Elevation $(\mathrm{ft})$ & Headwater Elevation $(\mathrm{ft})$ & Tailwater Elevation $(\mathrm{ft})$ \\
\hline 122 & 1500 & 1.09 & 1 gate only 595.6 & 630 & 585.8 \\
\hline
\end{tabular}

\section{Observation}

- Closed one gate with second gate open twice as high. Large eddy formed, but energy dissipates at end sill.

- No rock movement in exit channel.

\section{Test 123}

\begin{tabular}{|c|c|c|c|c|c|}
\hline Test \# & Prototype CFS & Model CFS & Gate Opening Elevation $(\mathrm{ft})$ & Headwater Elevation $(\mathrm{ft})$ & Tailwater Elevation $(\mathrm{ft})$ \\
\hline 123 & 2000 & 1.45 & 1 gate at 597.8 & 630 & $585.8 / 586.8 / 584.6 / 583.6$ \\
\hline
\end{tabular}

\section{Observation}

- Build rock up at end of concrete apron high than elevation of end of concrete apron.

- Started with low tailwater and increased or decreased by $1 \mathrm{ft}$ to see if rock would move.

- No rock movement in exit channel with any tailwater scenario.

\section{Test 124}

\begin{tabular}{|c|c|c|c|c|c|}
\hline Test \# & Prototype CFS & Model CFS & Gate Opening Elevation $(\mathrm{ft})$ & Headwater Elevation $(\mathrm{ft})$ & Tailwater Elevation $(\mathrm{ft})$ \\
\hline 124 & 2500 & 1.82 & 1 gate at 600.0 & 630 & 588.5 \\
\hline
\end{tabular}

\section{Observation}

- Only one gate open. No rock movement in exit channel. 
Test 125

\begin{tabular}{|c|c|c|c|c|c|}
\hline Test \# & Prototype CFS & Model CFS & Gate Opening Elevation $(\mathrm{ft})$ & Headwater Elevation $(\mathrm{ft})$ & Tailwater Elevation $(\mathrm{ft})$ \\
\hline 125 & 615 & 0.45 & 591.25 & 630 & 583.6 \\
\hline
\end{tabular}

\section{$\underline{\text { Observation }}$}

- Installed low slope fillet in front of end sill and placed 6 pieces of 18 inch gradation rock in basin.

- Flow oscillates left to right in basin.

- Four rocks moved down to start of fillet piece and two other rocks swirling in middle of basin.

\section{Test 126}

\begin{tabular}{|c|c|c|c|c|c|}
\hline Test \# & Prototype CFS & Model CFS & Gate Opening Elevation $(\mathrm{ft})$ & Headwater Elevation $(\mathrm{ft})$ & Tailwater Elevation $(\mathrm{ft})$ \\
\hline 126 & 1000 & 0.73 & 591.8 & 630 & 584.7 \\
\hline
\end{tabular}

\section{Observation}

- Flow oscillates left to right in basin.

- $\quad$ Five rocks move to just downstream of baffle block and slightly only fillet piece and one rock moved up to end of fillet and on top of end sill.

\section{Test 127}

\begin{tabular}{|c|c|c|c|c|c|}
\hline Test \# & Prototype CFS & Model CFS & Gate Opening Elevation $(\mathrm{ft})$ & Headwater Elevation $(\mathrm{ft})$ & Tailwater Elevation $(\mathrm{ft})$ \\
\hline 127 & 1500 & 1.09 & 592.8 & 630 & 585.8 \\
\hline
\end{tabular}

\section{$\underline{\text { Observation }}$}

- Flow mainly on left side of the basin

- All six rocks moved up to one-half to three-fourths of the way up on the concrete apron.

\section{Test 128}

\begin{tabular}{|c|c|c|c|c|c|}
\hline Test \# & Prototype CFS & Model CFS & Gate Opening Elevation $(\mathrm{ft})$ & Headwater Elevation $(\mathrm{ft})$ & Tailwater Elevation $(\mathrm{ft})$ \\
\hline 128 & 2000 & 1.45 & 593.9 & 630 & 586.8 \\
\hline
\end{tabular}

\section{$\underline{\text { Observation }}$}

- Flow uniform in basin.

- Four rocks flushed completely out past the end of the concrete apron and two rocks sit about three-fourths of the way up the concrete apron on the left side. 
Test 129

\begin{tabular}{|c|c|c|c|c|c|}
\hline Test \# & Prototype CFS & Model CFS & Gate Opening Elevation $(\mathrm{ft})$ & Headwater Elevation $(\mathrm{ft})$ & Tailwater Elevation $(\mathrm{ft})$ \\
\hline 129 & 2500 & 1.82 & 595 & 630 & 587.5 \\
\hline
\end{tabular}

Observation

- Same two rocks remained on the concrete apron.

- Uniform flow in basin.

Test 130

\begin{tabular}{|c|c|c|c|c|c|}
\hline Test \# & Prototype CFS & Model CFS & Gate Opening Elevation $(\mathrm{ft})$ & Headwater Elevation $(\mathrm{ft})$ & Tailwater Elevation (ft) \\
\hline 130 & 3000 & 2.18 & 596 & 630 & 588.1 \\
\hline
\end{tabular}

\section{Observation}

- All rocks flushed out past the concrete apron and into the riprap apron area.

- Flow is still uniform.

- Placed four very large rocks $\sim 2$ in. diameter in middle of basin. One rock moved all the way to end of concrete apron, and the rest sat about three-fourths up the concrete apron.

Test 131

\begin{tabular}{|c|c|c|c|c|c|}
\hline Test \# & Prototype CFS & Model CFS & Gate Opening Elevation (ft) & Headwater Elevation (ft) & Tailwater Elevation (ft) \\
\hline 131 & 3000 & 2.18 & 596 & 630 & 586.8 \\
\hline
\end{tabular}

\section{Observation}

- Rocks on concrete apron moved slightly more downstream where one rock moved completely downstream up on the riprap apron.

\section{Test 132}

\begin{tabular}{|c|c|c|c|c|c|}
\hline Test \# & Prototype CFS & Model CFS & Gate Opening Elevation (ft) & Headwater Elevation (ft) & Tailwater Elevation (ft) \\
\hline 132 & 3500 & 2.55 & 597 & 630 & 588.6 \\
\hline
\end{tabular}

\section{Observation}

- Rocks moved more closer to end of apron but not quite to the end. Picked up large rock that was on the riprap apron and put it back in the basin. It quickly moved back up to the end of the concrete apron. 
Test 133

\begin{tabular}{|c|c|c|c|c|c|}
\hline Test \# & Prototype CFS & Model CFS & Gate Opening Elevation $(\mathrm{ft})$ & Headwater Elevation $(\mathrm{ft})$ & Tailwater Elevation $(\mathrm{ft})$ \\
\hline 133 & 3500 & 2.55 & 597 & 630 & 587.3 \\
\hline
\end{tabular}

Observation

- No change from previous test.

\section{Test 134}

\begin{tabular}{|c|c|c|c|c|c|}
\hline Test \# & Prototype CFS & Model CFS & Gate Opening Elevation $(\mathrm{ft})$ & Headwater Elevation $(\mathrm{ft})$ & Tailwater Elevation $(\mathrm{ft})$ \\
\hline 134 & 1000 & 0.73 & 591.8 & 630 & 584.7 \\
\hline
\end{tabular}

\section{Observation}

- Installed high-sloping fillet in front of end sill to compare to lowsloping fillet further.

- Put six rocks with 18 in. gradation into stilling basin. All rocks swirled around, but none moved up on the fillet. Never went past downstream face of baffle blocks.

\section{Test 135}

\begin{tabular}{|c|c|c|c|c|c|}
\hline Test \# & Prototype CFS & Model CFS & Gate Opening Elevation $(\mathrm{ft})$ & Headwater Elevation $(\mathrm{ft})$ & Tailwater Elevation $(\mathrm{ft})$ \\
\hline 135 & 1500 & 1.09 & 592.8 & 630 & 585.8 \\
\hline
\end{tabular}

\section{Observation}

- Most rocks moved to start of fillet piece and swirling around within the same area,

- Flow congregated on left side of basin.

\section{Test 136}

\begin{tabular}{|c|c|c|c|c|c|}
\hline Test \# & Prototype CFS & Model CFS & Gate Opening Elevation $(\mathrm{ft})$ & Headwater Elevation $(\mathrm{ft})$ & Tailwater Elevation $(\mathrm{ft})$ \\
\hline 136 & 2000 & 1.45 & 593.9 & 630 & 586.8 \\
\hline
\end{tabular}

\section{Observation}

- Rocks grouped up at toe of fillet piece on right side of the basin,

- Flow congregated on left side of basin. 
Test 137

\begin{tabular}{|c|c|c|c|c|c|}
\hline Test \# & Prototype CFS & Model CFS & Gate Opening Elevation $(\mathrm{ft})$ & Headwater Elevation $(\mathrm{ft})$ & Tailwater Elevation $(\mathrm{ft})$ \\
\hline 137 & 2500 & 1.82 & 595 & 630 & 587.5 \\
\hline
\end{tabular}

Observation

- Same observations as previous tested. No rock flushed out.

\section{Test 138}

\begin{tabular}{|c|c|c|c|c|c|}
\hline Test \# & Prototype CFS & Model CFS & Gate Opening Elevation $(\mathrm{ft})$ & Headwater Elevation $(\mathrm{ft})$ & Tailwater Elevation $(\mathrm{ft})$ \\
\hline 138 & 4000 & 2.81 & 598.1 & 630 & 589.1 \\
\hline
\end{tabular}

\section{Observation}

- Removed high-sloping fillet and replaced with low-sloping fillet to continue testing to max design with low-slope fillet in.

- Flow uniform in basin and boiling up just past end sill.

- Threw three rocks in basin, and they were quickly flushed out to riprap apron area.

\section{Test 139}

\begin{tabular}{|c|c|c|c|c|c|}
\hline Test \# & Prototype CFS & Model CFS & Gate Opening Elevation $(\mathrm{ft})$ & Headwater Elevation $(\mathrm{ft})$ & Tailwater Elevation $(\mathrm{ft})$ \\
\hline 139 & 4000 & 2.81 & 598.1 & 630 & 587.7 \\
\hline
\end{tabular}

\section{Observation}

- Flow uniform in basin.

- No rock movement in riprap channel area.

\section{Test 140}

\begin{tabular}{|c|c|c|c|c|c|}
\hline Test \# & Prototype CFS & Model CFS & Gate Opening Elevation (ft) & Headwater Elevation (ft) & Tailwater Elevation (ft) \\
\hline 140 & 4500 & 3.27 & 599.2 & 630 & 589.5 \\
\hline
\end{tabular}

\section{Observation}

- Same observation as previous test. 
Test 141

\begin{tabular}{|c|c|c|c|c|c|}
\hline Test \# & Prototype CFS & Model CFS & Gate Opening Elevation $(\mathrm{ft})$ & Headwater Elevation $(\mathrm{ft})$ & Tailwater Elevation $(\mathrm{ft})$ \\
\hline 141 & 4500 & 3.27 & 599.2 & 630 & 588.2 \\
\hline
\end{tabular}

Observation

- Same observation as previous test.

\section{Test 142}

\begin{tabular}{|c|c|c|c|c|c|}
\hline Test \# & Prototype CFS & Model CFS & Gate Opening Elevation (ft) & Headwater Elevation (ft) & Tailwater Elevation (ft) \\
\hline 142 & 5000 & 3.64 & 600.1 & 630 & 589.9 \\
\hline
\end{tabular}

\section{Observation}

- Same observation as previous test.

\section{Test 143}

\begin{tabular}{|c|c|c|c|c|c|}
\hline Test \# & Prototype CFS & Model CFS & Gate Opening Elevation $(\mathrm{ft})$ & Headwater Elevation $(\mathrm{ft})$ & Tailwater Elevation $(\mathrm{ft})$ \\
\hline 143 & 6000 & 4.36 & 602.1 & 630 & 590.6 \\
\hline
\end{tabular}

\section{Observation}

- Flow starting to become pretty turbulent.

- Boiling up right around the end sill.

- Small rock in 36 in. zone shaking slightly but none moved upstream or downstream.

- Small back roller present in middle of fillet piece and concrete apron. However, rock that was placed in this zone would move upstream some but eventually would get pushed all the way downstream into the riprap apron area. No rock moved upstream form the riprap apron area.

\section{Test 144}

\begin{tabular}{|c|c|c|c|c|c|}
\hline Test \# & Prototype CFS & Model CFS & Gate Opening Elevation (ft) & Headwater Elevation (ft) & Tailwater Elevation (ft) \\
\hline 144 & 7000 & 5.09 & 605 & 632 & 591.3 \\
\hline
\end{tabular}

\section{Observation}

- Flow still pretty turbulent.

- Boiling just past end sill.

- Small rock in 36 in. zone shook slightly and rolled downstream 1 in. and stopped. Did not move any farther. 
Test 145

\begin{tabular}{|l|l|l|l|l|l|}
\hline Test \# & Prototype CFS & Model CFS & Gate Opening Elevation (ft) & Headwater Elevation (ft) & Tailwater Elevation (ft) \\
\hline
\end{tabular}

\begin{tabular}{l|l|c|c|c|c|}
\hline 145 & 8000 & 5.82 & 605 & 641 & 591.9 \\
\hline
\end{tabular}

Observation

- Flow very turbulent.

- Small rock in 36 in. zone shook slightly and rolled downstream 2 in.s and stopped. Did not move any farther.

\section{Test 146}

\begin{tabular}{|c|c|c|c|c|c|}
\hline Test \# & Prototype CFS & Model CFS & Gate Opening Elevation (ft) & Headwater Elevation (ft) & Tailwater Elevation (ft) \\
\hline 146 & 9300 & 6.76 & 605 & 657 & 592.7 \\
\hline
\end{tabular}

\section{Observation}

- Flow very turbulent.

- Five rocks rolled down sides of exit channel down into center of exit channel.

- Few more rocks shaking around in exit channel and rolled downstream a few inches further.

- Some slight damage to the exit channel but nothing major.

\section{Test 147}

\begin{tabular}{|c|c|c|c|c|c|}
\hline Test \# & Prototype CFS & Model CFS & Gate Opening Elevation $(\mathrm{ft})$ & Headwater Elevation $(\mathrm{ft})$ & Tailwater Elevation $(\mathrm{ft})$ \\
\hline 147 & 1500 & 1.09 & 592.8 & 630 & 585.8 \\
\hline
\end{tabular}

\section{Observation}

- Installed inverted $\mathrm{V}$ in parabolic drop with no fillet pieces present in stilling basin.

- Uniform flow in basin and less turbulent on the bottom of the basin as compared to without the inverted $\mathrm{V}$ installed. 


\section{Test 148}

\begin{tabular}{|c|c|c|c|c|c|}
\hline Test \# & Prototype CFS & Model CFS & Gate Opening Elevation $(\mathrm{ft})$ & Headwater Elevation $(\mathrm{ft})$ & Tailwater Elevation $(\mathrm{ft})$ \\
\hline 148 & 1000 & 0.73 & 591.8 & 630 & 584.7 \\
\hline
\end{tabular}

\section{Observation}

- Flow is split evenly within basin.

- Rocks that were placed in the basin congregated at toe of parabolic drop and did not swirl around.

- Eddy present on both sides of the basin and roll to the center of the basin.

\section{Test 149}

\begin{tabular}{|c|c|c|c|c|c|}
\hline Test \# & Prototype CFS & Model CFS & Gate Opening Elevation (ft) & Headwater Elevation $(\mathrm{ft})$ & Tailwater Elevation (ft) \\
\hline 149 & 615 & 0.45 & 591.25 & 630 & 583.6 \\
\hline
\end{tabular}

\section{Observation}

- Noticeably less turbulent in the stilling basin.

- Rocks still gathered in small area at toe of parabolic drop.

- Uniform flow present.

- Rocks in bottom of basin do not swirl around.

Test 150

\begin{tabular}{|c|c|c|c|c|c|}
\hline Test \# & Prototype CFS & Model CFS & Gate Opening Elevation $(\mathrm{ft})$ & Headwater Elevation $(\mathrm{ft})$ & Tailwater Elevation $(\mathrm{ft})$ \\
\hline 150 & 150 & 0.11 & 590.3 & 630 & 581.8 \\
\hline
\end{tabular}

\section{Observation}

- Hardly any flow present in basin with absolutely no turbulence.

- Rocks are still and do not move around.

\section{Test 151}

\begin{tabular}{|c|c|c|c|c|c|}
\hline Test \# & Prototype CFS & Model CFS & Gate Opening Elevation $(\mathrm{ft})$ & Headwater Elevation $(\mathrm{ft})$ & Tailwater Elevation $(\mathrm{ft})$ \\
\hline 151 & 2000 & 1.45 & 593.9 & 630 & 586.8 \\
\hline
\end{tabular}

\section{Observation}

- $\quad$ Boiling up near upstream side of baffle blocks.

- Larger rock that was placed within the basin are stationary whereas the smaller rock are swirling around some.

- Flow is uniform in the basin. 
Test 152

\begin{tabular}{|l|l|l|l|l|l|}
\hline Test \# & Prototype CFS & Model CFS & Gate Opening Elevation (ft) & Headwater Elevation (ft) & Tailwater Elevation (ft) \\
\hline
\end{tabular}

\begin{tabular}{|c|c|c|c|c|c|}
\hline 152 & 2500 & 1.82 & 595 & 630 & 587.5 \\
\hline
\end{tabular}

\section{Observation}

- Flow is still fairly uniform with a slightly a higher flow on the left side vs the right side of the basin.

- Still boiling up just on the upstream side of the baffle blocks.

- Larger rock still not moving and smaller rock still swirling around.

- Most rocks are staying between the baffle blocks and the end sill.

\section{Test 153}

\begin{tabular}{|c|c|c|c|c|c|}
\hline Test \# & Prototype CFS & Model CFS & Gate Opening Elevation $(\mathrm{ft})$ & Headwater Elevation $(\mathrm{ft})$ & Tailwater Elevation (ft) \\
\hline 153 & 3000 & 2.18 & 596 & 630 & 588.1 \\
\hline
\end{tabular}

\section{Observation}

- Small rocks still swirling around between the baffle blocks and end sill.

- Boiling up directly over baffle blocks.

- Larger rock starting to remove around some.

- Flow uniform in basin and entering exit channel fairly calmly .

\section{Test 154}

\begin{tabular}{|c|c|c|c|c|c|}
\hline Test \# & Prototype CFS & Model CFS & Gate Opening Elevation $(\mathrm{ft})$ & Headwater Elevation $(\mathrm{ft})$ & Tailwater Elevation $(\mathrm{ft})$ \\
\hline 154 & 3500 & 2.55 & 597 & 630 & 588.6 \\
\hline
\end{tabular}

\section{Observation}

- Boiling up just past baffle blocks.

- Larger rock moving around some with smaller rock still moving around greatly. 
Test 155

\begin{tabular}{|l|l|l|l|l|l|}
\hline Test \# & Prototype CFS & Model CFS & Gate Opening Elevation $(\mathrm{ft})$ & Headwater Elevation $(\mathrm{ft})$ & Tailwater Elevation $(\mathrm{ft})$ \\
\hline
\end{tabular}

\begin{tabular}{l|c|c|c|c|c|}
\hline 155 & 4000 & 2.81 & 598.1 & 630 & 589.1 \\
\hline
\end{tabular}

Observation

- Small rocks came out of the basin onto the concrete apron but then was pulled back down into the basin.

- All rocks moving around between baffle blocks and end sill. Smaller rock jumping off of the bottom of the basin.

- Flow is uniform and boiling up just past baffle block.

Test 156

\begin{tabular}{|c|c|c|c|c|c|}
\hline Test \# & Prototype CFS & Model CFS & Gate Opening Elevation (ft) & Headwater Elevation (ft) & Tailwater Elevation (ft) \\
\hline 156 & 5000 & 3.64 & 600.1 & 630 & 589.9 \\
\hline
\end{tabular}

\section{Observation}

- Smaller rock flushed out of basin and one larger rock flushed of basin as well.

- Boiling up near end sill.

- Rocks still in basin are being thrown around violently.

- Flow is noticeably more turbulent but still uniform.

\section{Test 157}

\begin{tabular}{|c|c|c|c|c|c|}
\hline Test \# & Prototype CFS & Model CFS & Gate Opening Elevation $(\mathrm{ft})$ & Headwater Elevation $(\mathrm{ft})$ & Tailwater Elevation $(\mathrm{ft})$ \\
\hline 157 & 6000 & 4.36 & 602.1 & 630 & 590.6 \\
\hline
\end{tabular}

\section{Observation}

- Only one large rock remains in the basin where all other rocks have been flushed out.

- Flow is turbulent with boiling up past the end sill 


\section{Test 158}

\begin{tabular}{|c|c|c|c|c|c|}
\hline Test \# & Prototype CFS & Model CFS & Gate Opening Elevation (ft) & Headwater Elevation $(\mathrm{ft})$ & Tailwater Elevation $(\mathrm{ft})$ \\
\hline 158 & 8000 & 5.82 & 605 & 641 & 591.3 \\
\hline
\end{tabular}

\section{$\underline{\text { Observation }}$}

- No rocks left in the basin and all were flushed out.

- Flow is very turbulent and boiling up one-half up over the concrete apron.

- Starting to notice with the higher flows, the basin is more turbulent than without the inverted V. Also, rocks were flushed out of the basin quicker than without inverted V installed. Rocks in 36 in. zone are shaking around pretty good. Flow coming out of basin seems to be higher as well.

\section{Test 159}

\begin{tabular}{|c|c|c|c|c|c|}
\hline Test \# & Prototype CFS & Model CFS & Gate Opening Elevation $(\mathrm{ft})$ & Headwater Elevation $(\mathrm{ft})$ & Tailwater Elevation $(\mathrm{ft})$ \\
\hline 159 & 9300 & 6.76 & 605 & 657 & 592.7 \\
\hline
\end{tabular}

\section{$\underline{\text { Observation }}$}

- Flow still seems to be very turbulent, more turbulent that without inverted $\mathrm{V}$.

- Some rocks were moved in the 36 in. zone downstream.

- Decent amount of rocks also fell down side slopes and landed in channel.

- Once water was shut off, noticed rocks at the end of the 36 in. gradation zone moved downstream as well.

- Did not notice this much rock movement than without inverted V test.

\section{Test 160}

\begin{tabular}{|c|c|c|c|c|c|}
\hline Test \# & Prototype CFS & Model CFS & Gate Opening Elevation $(\mathrm{ft})$ & Headwater Elevation $(\mathrm{ft})$ & Tailwater Elevation (ft) \\
\hline 160 & 615 & 0.45 & 591.25 & 630 & 583.6 \\
\hline
\end{tabular}

\section{Observation}

- Added low-slope fillet in front of end sill in conjunction with inverted $\mathrm{V}$.

- No rock movement. All rocks located at toe of parabolic drop.

- Flow is split evenly across stilling basin. 
Test 161

\begin{tabular}{|l|l|l|l|l|l|}
\hline Test \# & Prototype CFS & Model CFS & Gate Opening Elevation (ft) & Headwater Elevation (ft) & Tailwater Elevation (ft) \\
\hline
\end{tabular}

\begin{tabular}{l|c|c|c|c|c|}
\hline 161 & 1000 & 0.73 & 591.8 & 630 & 584.7 \\
\hline
\end{tabular}

Observation

- No rock movement with all rocks still at toe of parabolic drop.

\section{Test 162}

\begin{tabular}{|c|c|c|c|c|c|}
\hline Test \# & Prototype CFS & Model CFS & Gate Opening Elevation $(\mathrm{ft})$ & Headwater Elevation $(\mathrm{ft})$ & Tailwater Elevation $(\mathrm{ft})$ \\
\hline 162 & 1500 & 1.09 & 592.8 & 630 & 585.8 \\
\hline
\end{tabular}

\section{Observation}

- Smaller rock moved up fillet piece and concrete apron. Larger rocks still in basin near baffles and toe of fillet piece.

- One small rock was noticed to move all the way up to apron but then get pulled down into the basin.

- Inverted V is causing an eddy and low-pressure area in the middle of the basin causing rocks that normally would be flushed out to be pulled back down into the basin.

Test 163

\begin{tabular}{|c|c|c|c|c|c|}
\hline Test \# & Prototype CFS & Model CFS & Gate Opening Elevation $(\mathrm{ft})$ & Headwater Elevation $(\mathrm{ft})$ & Tailwater Elevation $(\mathrm{ft})$ \\
\hline 163 & 2000 & 1.45 & 593.9 & 630 & 586.8 \\
\hline
\end{tabular}

\section{Observation}

- More rock moved up onto the concrete apron where larger rock still present in the basin upstream of the baffle blocks.

- Same eddy in the middle of basin causing rock to be pulled out of basin and then back in.

- Flow is uniform and boiling up halfway between baffle blocks and parabolic drop. 
Test 164

\begin{tabular}{|l|l|l|l|l|l|}
\hline Test \# & Prototype CFS & Model CFS & Gate Opening Elevation (ft) & Headwater Elevation (ft) & Tailwater Elevation (ft) \\
\hline
\end{tabular}

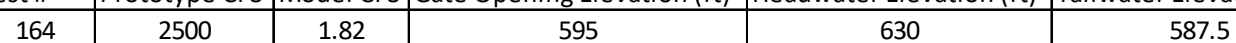

Observation

- Larger rock still sitting in front of the baffle blocks and not moving downstream.

- Inverted V still causing eddy in middle of basin affecting rocks to be flushed out.

- Uniform flow present.

\section{Test 165}

\begin{tabular}{|c|c|c|c|c|c|}
\hline Test \# & Prototype CFS & Model CFS & Gate Opening Elevation (ft) & Headwater Elevation (ft) & Tailwater Elevation (ft) \\
\hline 165 & 3000 & 2.18 & 596 & 630 & 588.1 \\
\hline
\end{tabular}

\section{Observation}

- Uniform flow present.

- Rocks still not flushing out and congregated at toe of fillet.

Test 166

\begin{tabular}{|c|c|c|c|c|c|}
\hline Test \# & Prototype CFS & Model CFS & Gate Opening Elevation $(\mathrm{ft})$ & Headwater Elevation $(\mathrm{ft})$ & Tailwater Elevation $(\mathrm{ft})$ \\
\hline 166 & 3500 & 2.55 & 597 & 630 & 588.6 \\
\hline
\end{tabular}

\section{Observation}

- Same observation as previous test.

\section{Test 167}

\begin{tabular}{|c|c|c|c|c|c|}
\hline Test \# & Prototype CFS & Model CFS & Gate Opening Elevation (ft) & Headwater Elevation (ft) & Tailwater Elevation (ft) \\
\hline 167 & 4000 & 2.81 & 598.1 & 630 & 589.1 \\
\hline
\end{tabular}

\section{Observation}

- All but one rock flushed out of basin. The remaining rock would go about three-fourths of the way up the fillet and then get pulled back down into the basin. 
Test 168

\begin{tabular}{|l|l|l|l|l|l|}
\hline Test \# & Prototype CFS & Model CFS & Gate Opening Elevation (ft) & Headwater Elevation (ft) & Tailwater Elevation (ft) \\
\hline
\end{tabular}

\begin{tabular}{l|l|c|c|c|c|}
\hline 168 & 4500 & 3.27 & 599.2 & 630 & 589.5 \\
\hline
\end{tabular}

Observation

- All rocks now flushed out.

- Placed hand in middle of stilling basin and noticed hardly in flow present. Placed very large rock in middle of basin, and it did not move but did move out on sides of basin.

Test 169

\begin{tabular}{|c|c|c|c|c|c|}
\hline Test \# & Prototype CFS & Model CFS & Gate Opening Elevation (ft) & Headwater Elevation (ft) & Tailwater Elevation (ft) \\
\hline 169 & 7000 & 5.09 & 605 & 632 & 591.3 \\
\hline
\end{tabular}

Observation

- Uniform flow but very turbulent.

- Mainly watching rock in 36 in. gradation zone and noticed some rock starting to roll out downstream from that area. Noticed some rock at start of 36 in. gradation zone. Larger rock shook and looked like it could go downstream.

- Decided to stop tests with the fear the channel might be damaged if a higher cubic feet per minute was present.

\section{Test 170}

\begin{tabular}{|c|c|c|c|c|c|}
\hline Test \# & Prototype CFS & Model CFS & Gate Opening Elevation (ft) & Headwater Elevation (ft) & Tailwater Elevation (ft) \\
\hline 170 & 615 & 0.45 & 591.25 & 630 & 583.6 \\
\hline
\end{tabular}

\section{Observation}

- Baffle blocks removed in stilling basin with no fillet or no inverted V present as well.

- Flow only on right side of the basin with eddy rolling to the left.

- Rocks placed in the basin. Smaller rock moved around slightly whereas larger rock stayed still. 
Test 171

\begin{tabular}{|l|l|l|l|l|l|}
\hline Test \# & Prototype CFS & Model CFS & Gate Opening Elevation (ft) & Headwater Elevation (ft) & Tailwater Elevation (ft) \\
\hline
\end{tabular}

\begin{tabular}{|c|c|c|c|c|c|}
\hline 171 & 1000 & 0.73 & 591.8 & 630 & 584.7 \\
\hline
\end{tabular}

Observation

- Flow is oscillating from left to right of basin.

- All rocks moved down toward end sill and are staying in that particular area.

- Small rocks moving around slightly and larger rock stationary.

\section{Test 172}

\begin{tabular}{|c|c|c|c|c|c|}
\hline Test \# & Prototype CFS & Model CFS & Gate Opening Elevation $(\mathrm{ft})$ & Headwater Elevation $(\mathrm{ft})$ & Tailwater Elevation (ft) \\
\hline 172 & 1500 & 1.09 & 592.8 & 630 & 585.8 \\
\hline
\end{tabular}

\section{Observation}

- Rocks started to move around greatly within the basin. One small rock came all the way upstream to the parabolic drop and shot back down the bottom of the basin.

- Fairly good size eddy noticeable with flow concentrated on the left side. Moving rocks around a good bit.

- Flow is picking up rocks high and throwing them downstream.

- Small rocks also picked up and taken almost to the water surface.

- Would cause considerable concrete scour if this condition was present in the field.

\section{Test 173}

\begin{tabular}{|c|c|c|c|c|c|}
\hline Test \# & Prototype CFS & Model CFS & Gate Opening Elevation $(\mathrm{ft})$ & Headwater Elevation $(\mathrm{ft})$ & Tailwater Elevation $(\mathrm{ft})$ \\
\hline 173 & 2000 & 1.45 & 593.9 & 630 & 586.8 \\
\hline
\end{tabular}

\section{Observation}

- Rocks are moving around near the end sill.

- Large rock being pulled up to parabolic drop and then thrown down in the basin.

- Large eddy still present in the basin.

- Two small rocks pulled up unto the concrete apron. 


\section{Test 174}

\begin{tabular}{|c|c|c|c|c|c|}
\hline Test \# & Prototype CFS & Model CFS & Gate Opening Elevation (ft) & Headwater Elevation (ft) & Tailwater Elevation (ft) \\
\hline 174 & 3000 & 2.18 & 596 & 630 & 588.1 \\
\hline
\end{tabular}

\section{Observation}

- Flow is starting to look better and more uniform.

- Rocks are starting to be pushed up and over the end sill onto the concrete apron.

- Rocks that didn't flush out are mainly congregated down by the end sill.

\section{Test 175}

\begin{tabular}{|c|c|c|c|c|c|}
\hline Test \# & Prototype CFS & Model CFS & Gate Opening Elevation $(\mathrm{ft})$ & Headwater Elevation $(\mathrm{ft})$ & Tailwater Elevation $(\mathrm{ft})$ \\
\hline 175 & 4000 & 2.81 & 598.1 & 630 & 589.1 \\
\hline
\end{tabular}

\section{Observation}

- Flow still looks better, uniform, and has a nice jump surprisingly.

- Small rock continuing to be pushed out of basin and onto apron.

- One larger rock did flush out of the basin onto the apron.

\section{Test 176}

\begin{tabular}{|c|c|c|c|c|c|}
\hline Test \# & Prototype CFS & Model CFS & Gate Opening Elevation (ft) & Headwater Elevation $(\mathrm{ft})$ & Tailwater Elevation (ft) \\
\hline 176 & 5000 & 3.64 & 600.1 & 630 & 589.9 \\
\hline
\end{tabular}

\section{Observation}

- Flow still looks fairly uniform with a nice hydraulic jump.

- Smaller rocks have been flushed out but larger rocks remained swirling in the basin.

- Noticed that more energy is being released into the exit channel due to not baffle blocks and the end sill acting as a baffle for the hydraulic jump. 


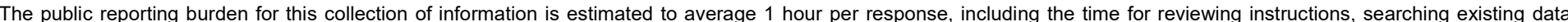

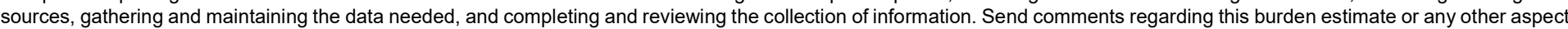

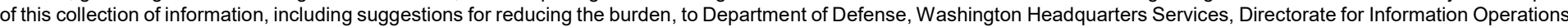

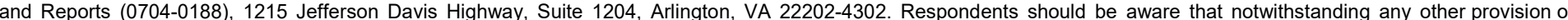
law, no person shall be subject to any penalty for failing to comply with a collection of information if it does not display a currently valid OMB control number.

PLEASE DO NOT RETURN YOUR FORM TO THE ABOVE ADDRESS.

\begin{tabular}{l|l|l}
\hline 1. REPORT DATE & 2. REPORT TYPE \\
December 2018 & Final Report
\end{tabular}

\section{TITLE AND SUBTITLE}

Physical Model Analysis of the Foster Joseph Sayers Dam 5a. CONTRACT NUMBER

5b. GRANT NUMBER

5c. PROGRAM ELEMENT NUMBER

5d. PROJECT NUMBER

122098

5e. TASK NUMBER

5f. WORK UNIT NUMBER

8. PERFORMING ORGANIZATION REPORT NUMBER

Coastal and Hydraulics Laboratory

U.S. Army Engineer Research and Development Center

3909 Halls Ferry Road

Vicksburg, MS 39180-6199

9. SPONSORING/MONITORING AGENCY NAME(S) AND ADDRESS(ES)

U.S. Army Corps of Engineers, Baltimore District

ERDC/CHL TR-18-18

2 Hopkins Plaza

Baltimore, MD 21201
10. SPONSOR/IO
USACE NAB

11. SPONSOR/MONITOR'S REPORT NUMBER(S)

\section{DISTRIBUTION/AVAILABILITY STATEMENT}

Approved for public release; distribution is unlimited.

\section{SUPPLEMENTARY NOTES}

\section{ABSTRACT}

Concrete degradation issues due to riprap entrainment have been observed in the stilling basin at Foster Joseph Sayers Dam. This entrapment occurs during normal flows. The original stilling basin has experienced excessive degradation, and repairs to restore it to original specifications are needed. A physical model study has been performed to determine the flow characteristics of the stilling basin and to develop a design modification to minimize riprap entrapment. The riprap originates in an area that could be replaced with a concrete pad to prevent further riprap entrainment in the stilling basin. A final stilling basin design modification recommendation is provided.

\section{SUBJECT TERMS}

Concrete-Deterioration, Foster Joseph Sayers Dam (Pa.), Hydraulic models, Hydraulic structure, Stilling basin

16. SECURITY CLASSIFICATION OF:

\begin{tabular}{|l|l|l|l|}
\hline a. REPORT & b. ABSTRACT & c. THIS PAGE & ABSTRACT \\
Unclassified & Unclassified & Unclassified & SAR \\
& & &
\end{tabular}

18. NUMBER OF PAGES

104 19a. NAME OF RESPONSIBLE PERSON

Benjamin Burnham

19b. TELEPHONE NUMBER (Include area code) 601-634-4251 